\begin{tabular}{c}
\hline $\begin{array}{c}\text { Journal of Home } \\
\text { Economics }\end{array}$ \\
\hline
\end{tabular}

http://homeEcon.menofia.edu.eg
مجلة الاقتصاد المنزلي

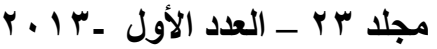

ISSN 1110-2578

\title{
ممارسة العنف ضد المرأة وأثره على أداء أدوارها الأسرية

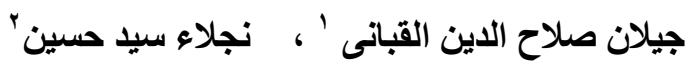

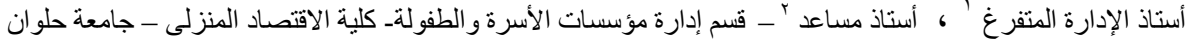

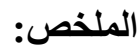

يهذف هذا البحث إلى الكثف عن أثر ممارسة العنف ضد المر أة على أدئ أداء أدوارها

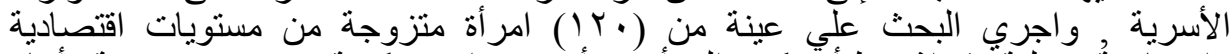

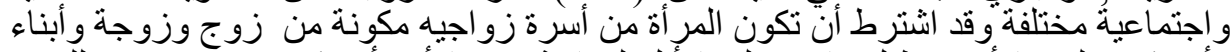

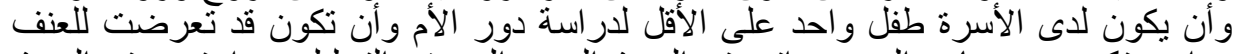

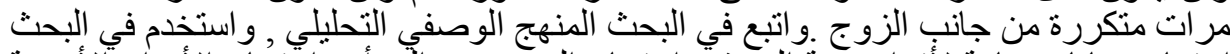

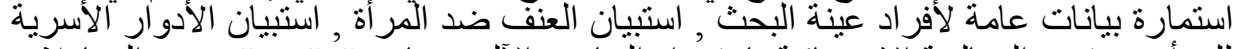

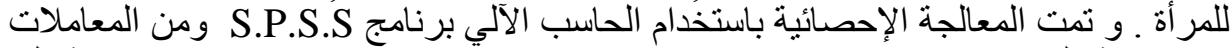

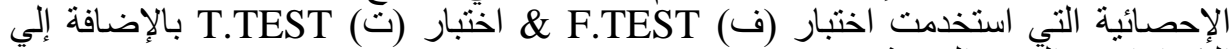
التكر ارات و النّبب المئوية النئ.

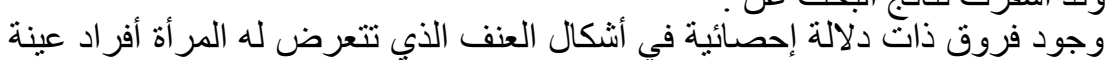

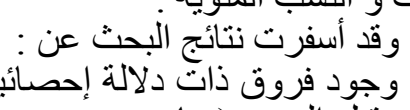

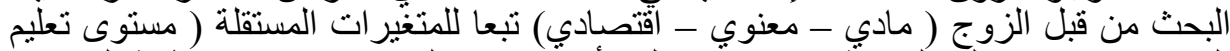

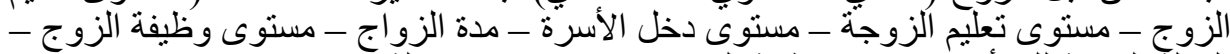

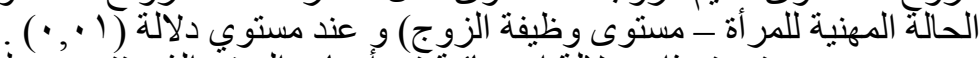

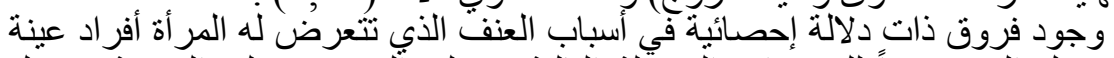

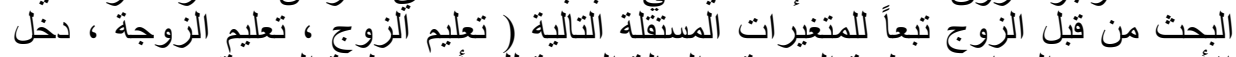

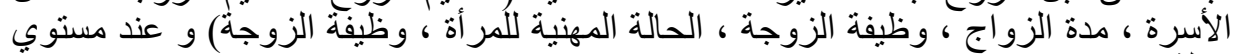

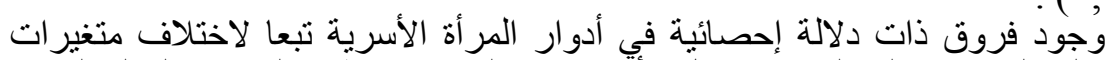

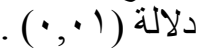

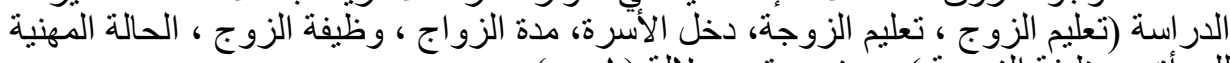

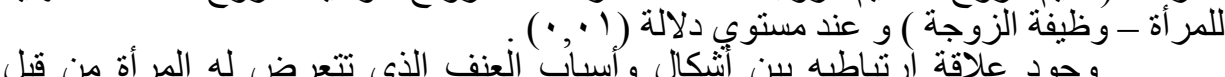

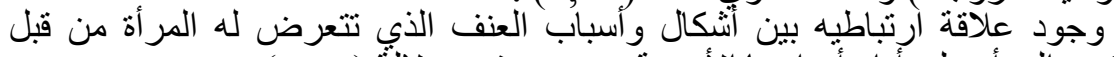

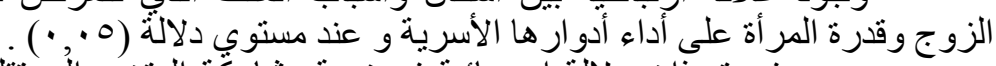

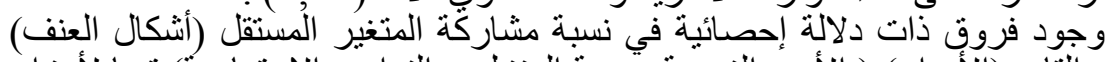

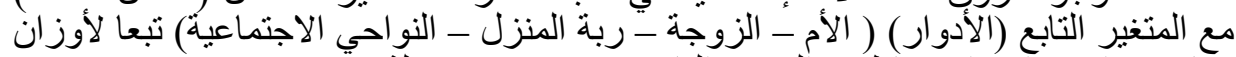

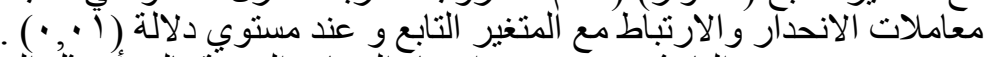

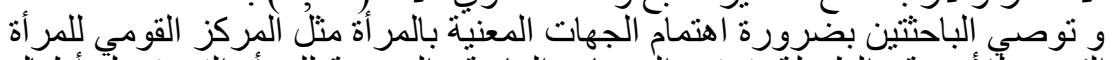

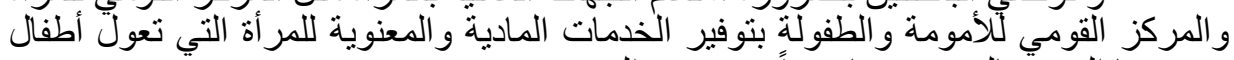
ويهجر ها الزوج بالنهوض بها بعيداً عن عنف الزوبرج. 


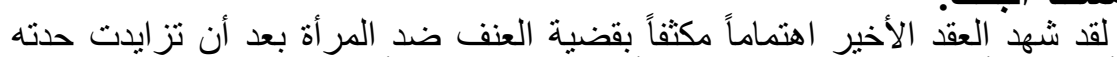

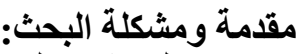

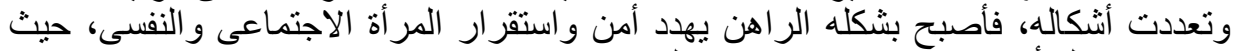

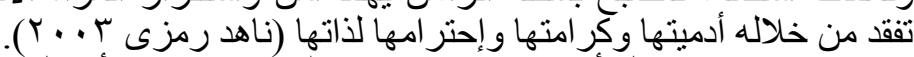

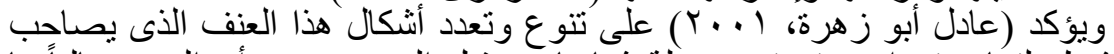

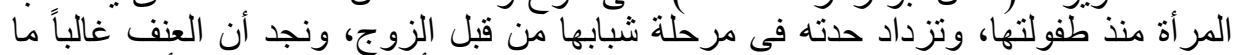

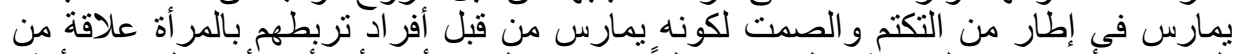

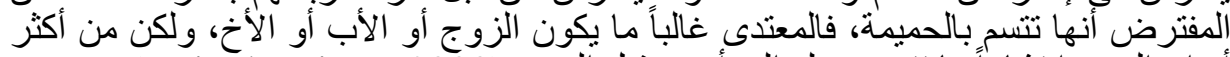

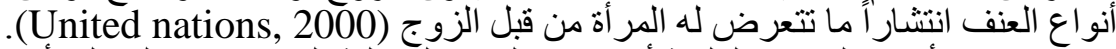

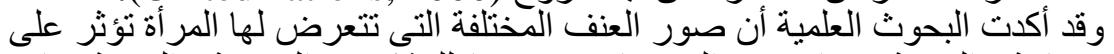

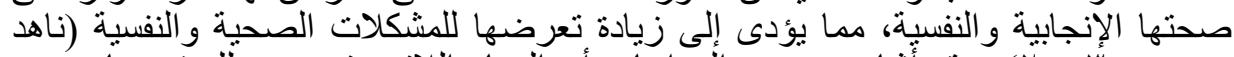

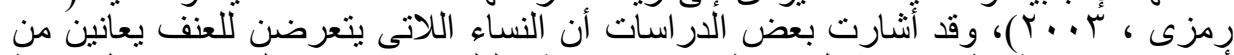

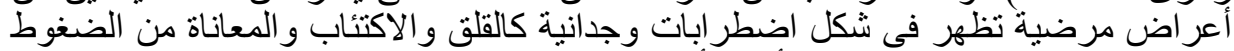

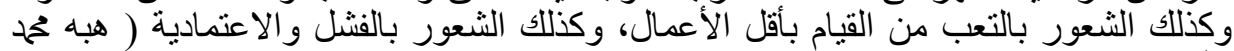

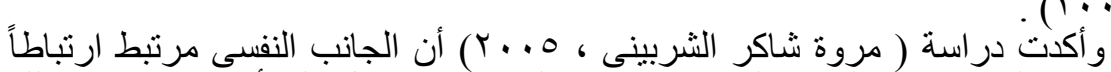

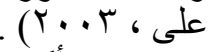

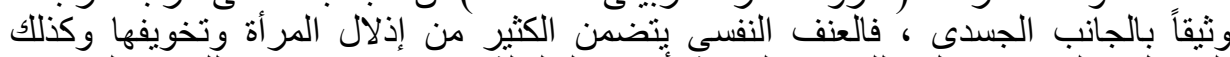

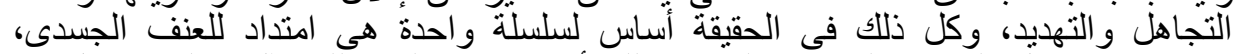

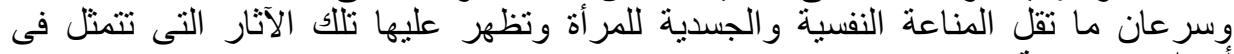
أعر اض مرضية. ولقد أُصبح العنف الذى يمارسه الزوج ضد المرأة من المشكلات التى نؤرق حياة

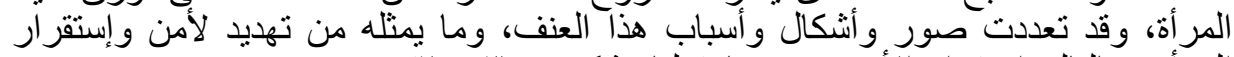

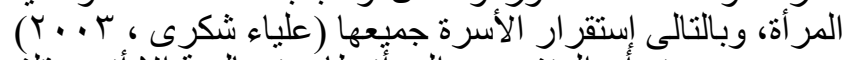

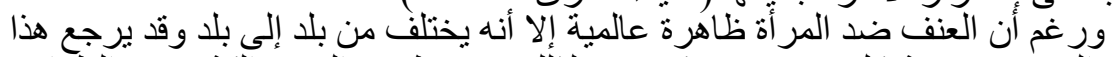

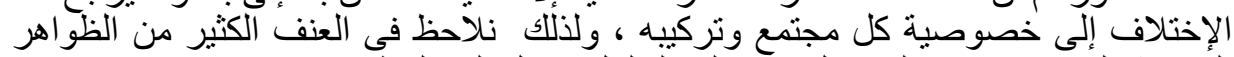

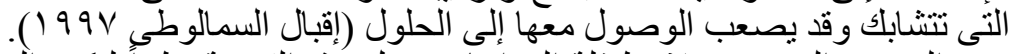

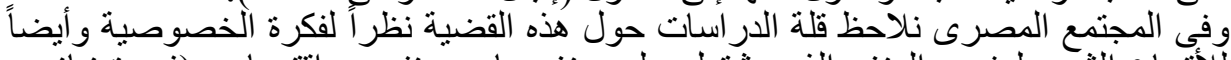

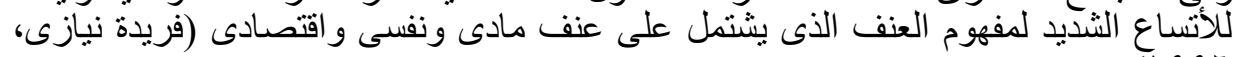

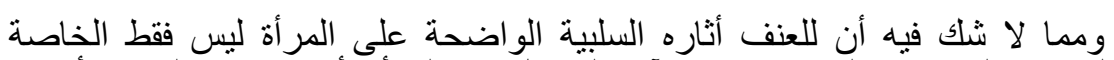
. (1997

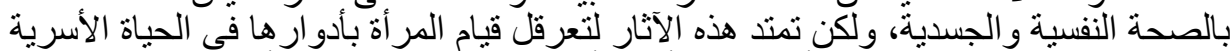

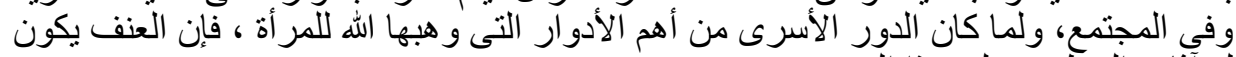

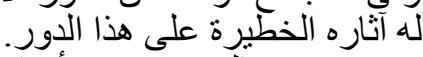

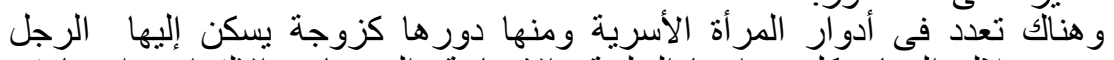

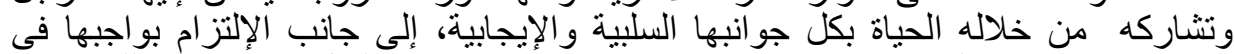

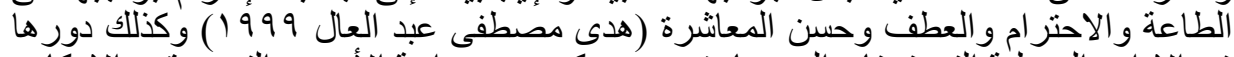

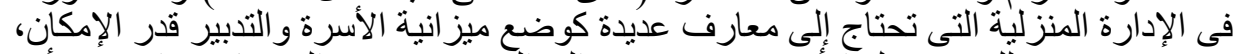

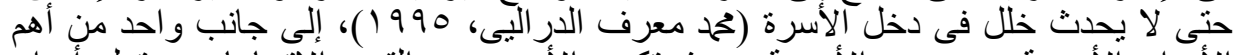

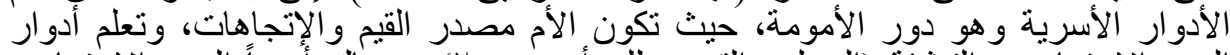

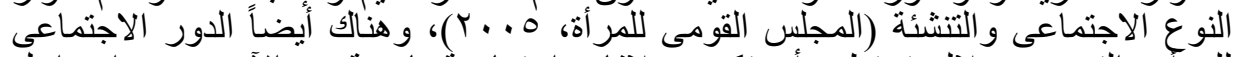

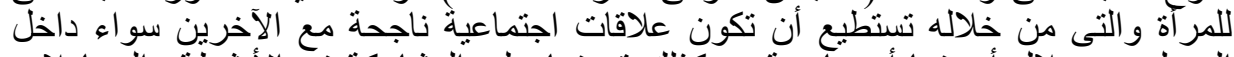

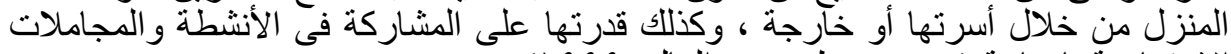

الاجتماعية بإيجابية (هدى مصطفى عبد العال، 1999 (1) ). 


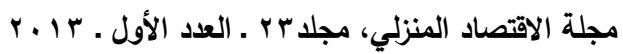

ولكن وجود العنف فى حياة المر أة يحدث لها تهديد واضح لهذه الأدوار، ويؤثر سلبا

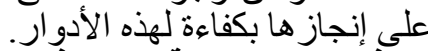

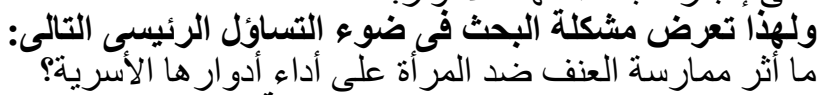

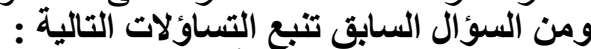

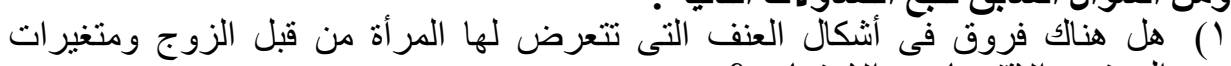

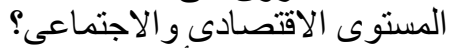

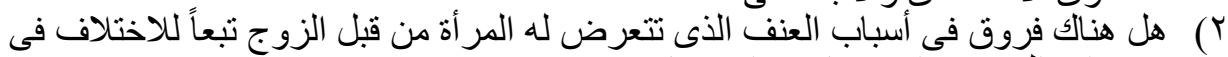

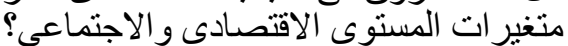
r) هل هناك فروق فى قدرة المرأة على أداء أدوار ها الأسرية تبعا للاختلاف فى متغيرات

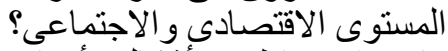

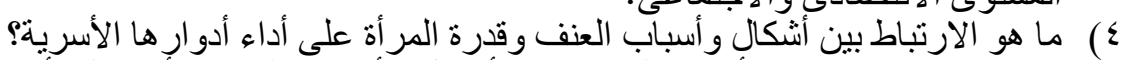

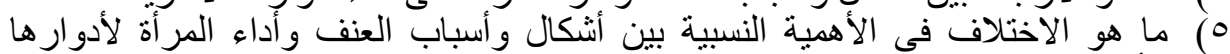
الأسرية؟ الأب:

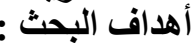

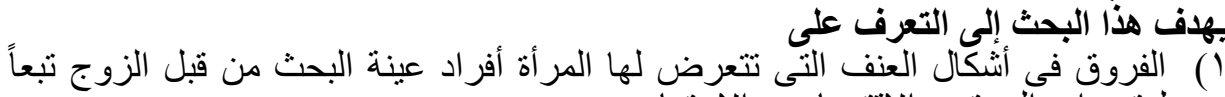

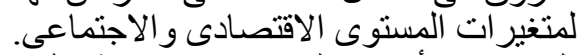

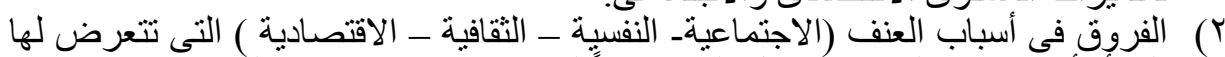

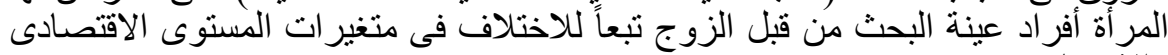

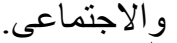

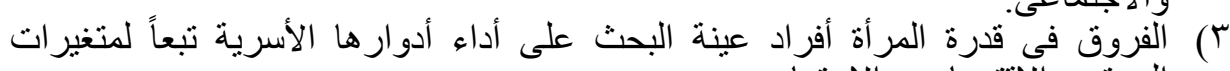

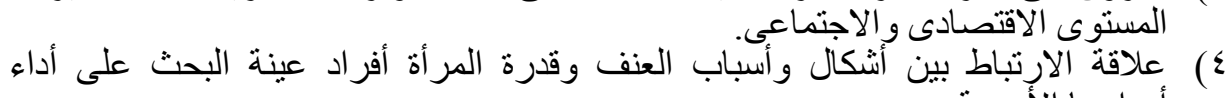
ه) الاختلاف فى الأهمية النسبية بين أثنكال العنف وأداء المرأة أفراد عينة البحث لأدوارها الأسرية.

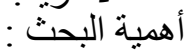

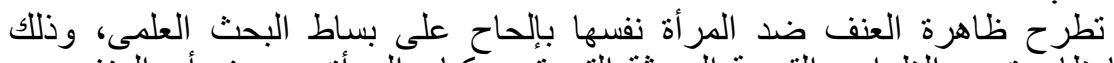

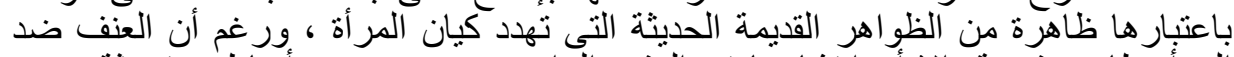

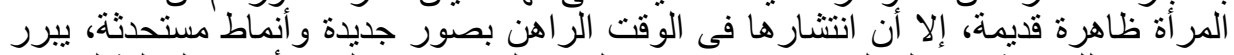

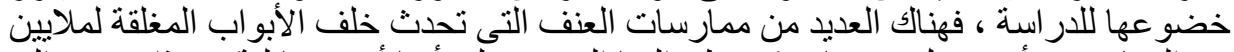

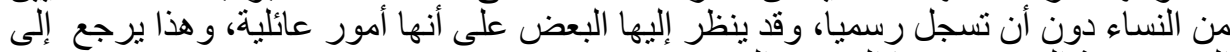

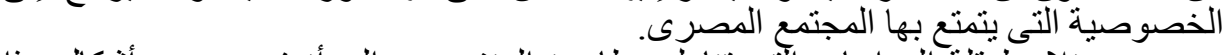

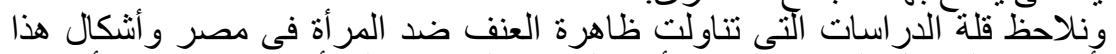

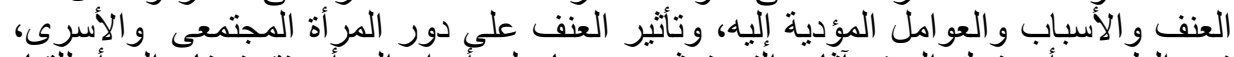

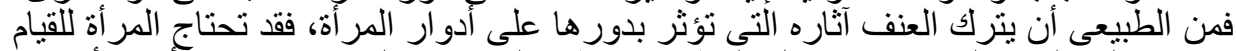

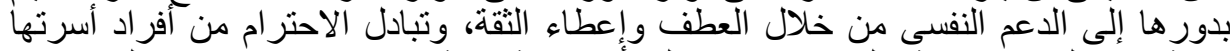

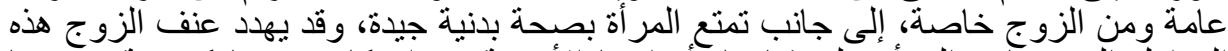

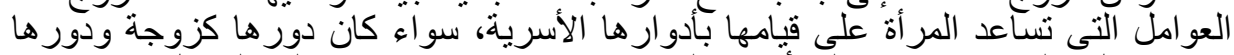

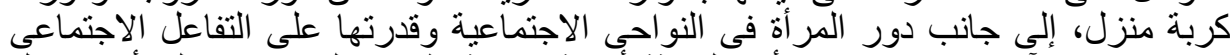

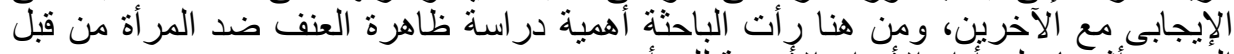
الزَّوج وأثرها على أداء الأدوار الأسرية للمر أثة 
القرض الأول: توجد فروف ذات دلالة إحصائية في أثكال العنف الذى تتعرض لله المر أة أفر اد

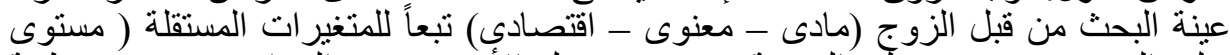

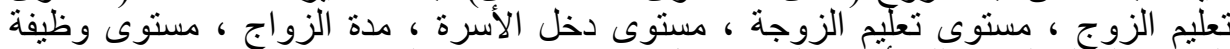

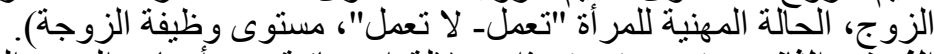

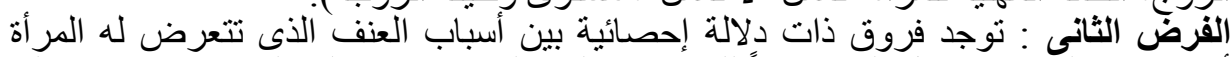

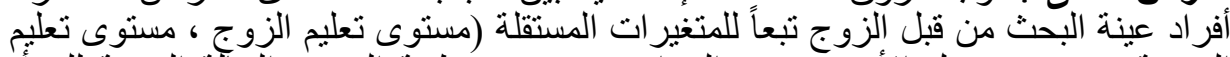

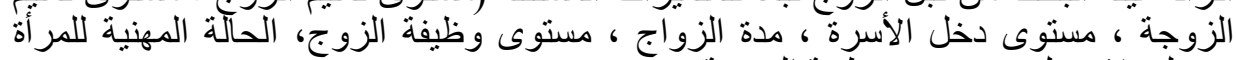

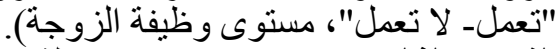

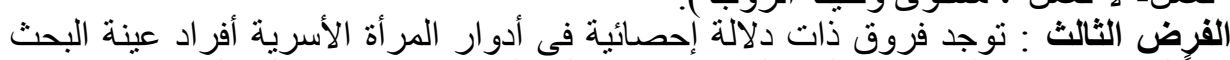

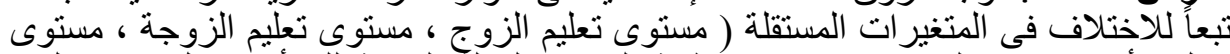

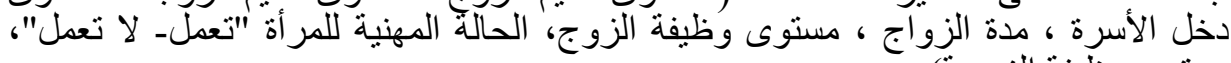
مستوى وظليفة الزوجة).

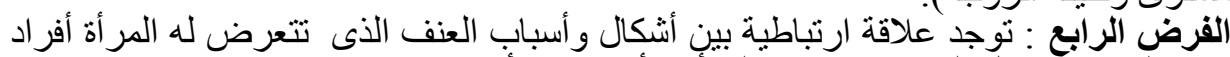

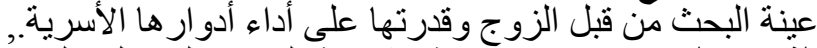

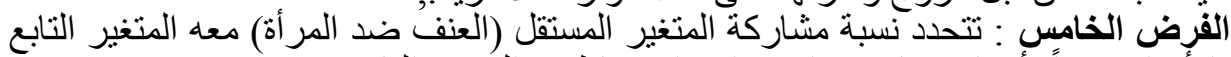

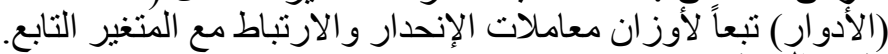

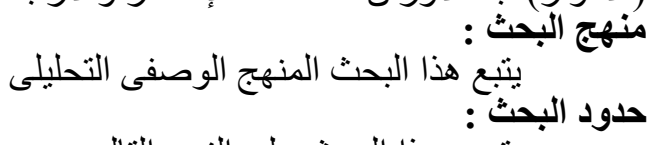
يتحدد هذا البحث على البح : النحو التالى :

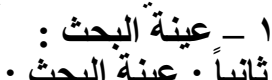

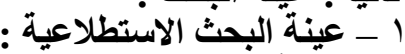

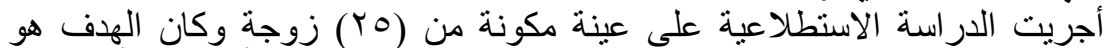

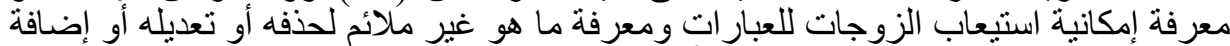

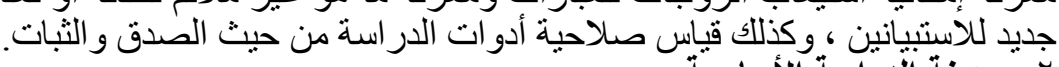

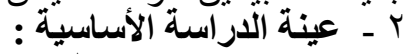

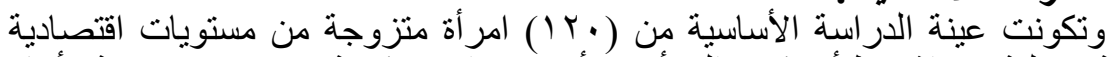

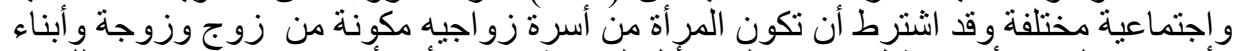

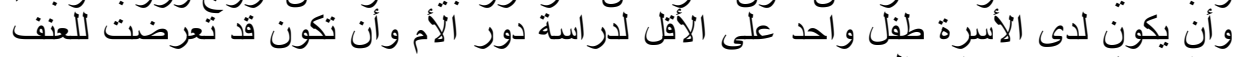

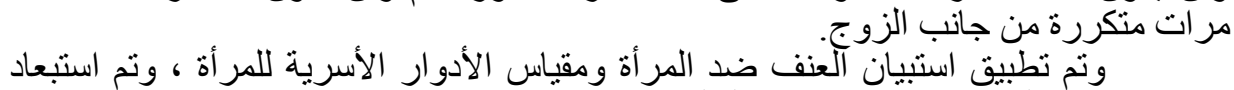

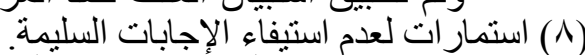

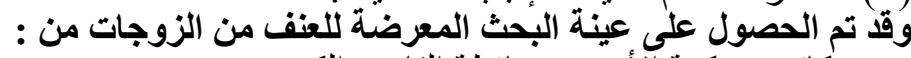

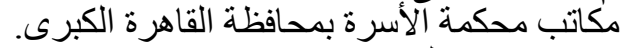
مكاتب بعض ماتب محكمة المحامين.

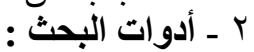

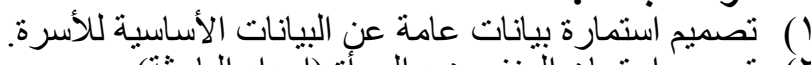

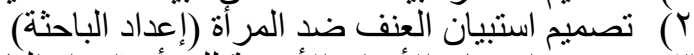
ب) تصميم استبيان الأدوار الأسرية للمر أة (إعداد الباحثة) 


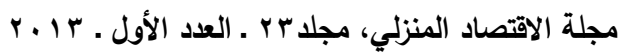

ثالثاً: إعداد ويناء أدوات البحث:

واشتملت أدوات الدار استة على :

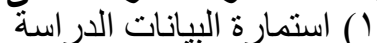

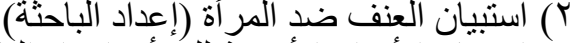

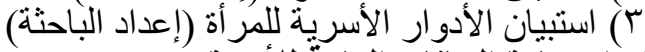

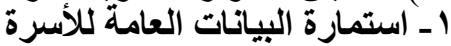

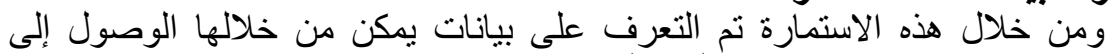

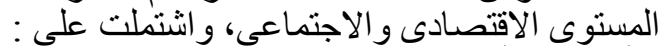

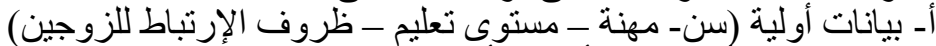

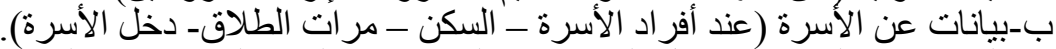

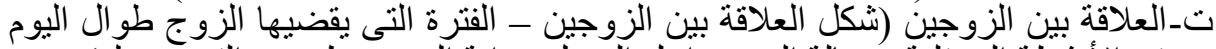

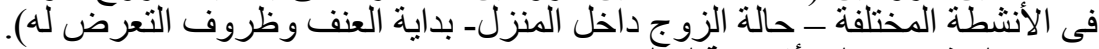

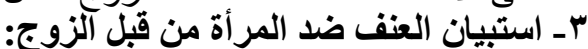

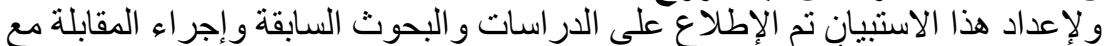

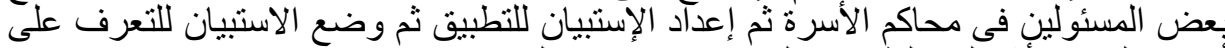

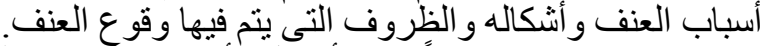

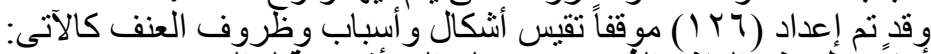

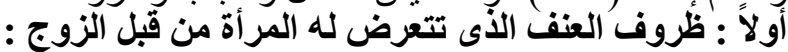

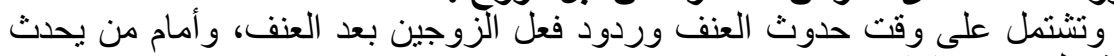

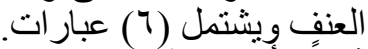

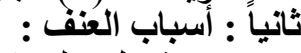

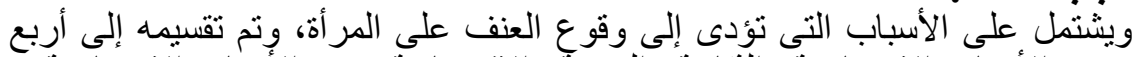

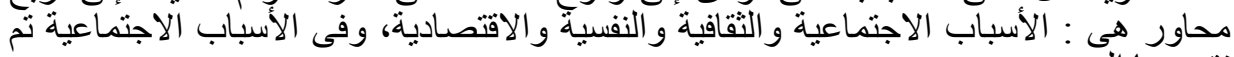

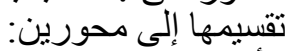

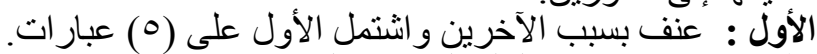

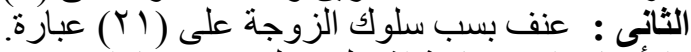

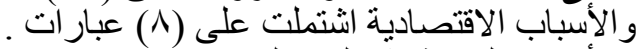

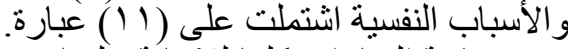

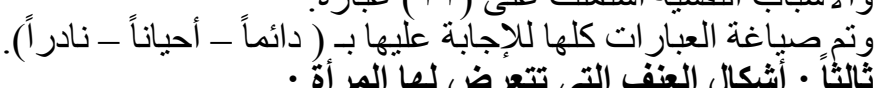

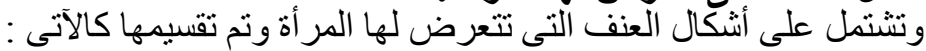

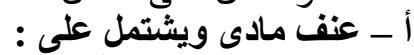

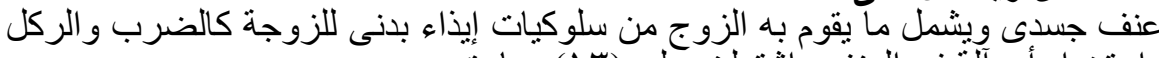

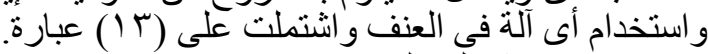

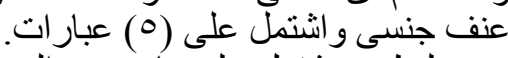

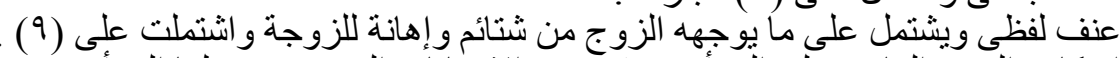

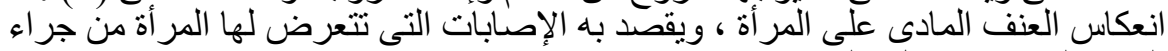

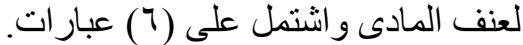
ب - عنف معنوى ( النفسى) : بلنئ

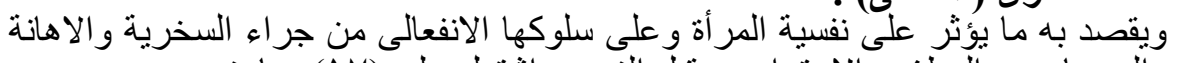

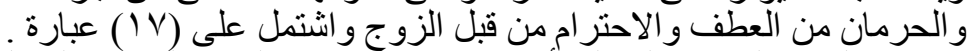

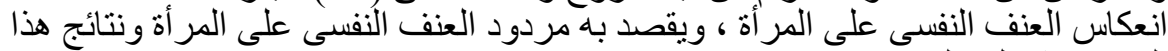
العنف واشتمل على (r العلى عبارة. 


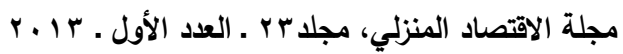

ج - العنف الاقتصادى :

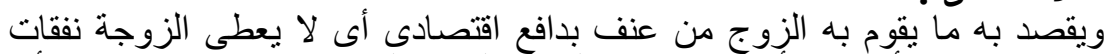

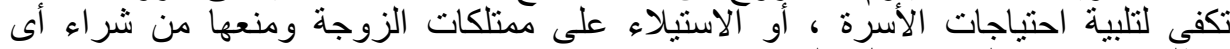

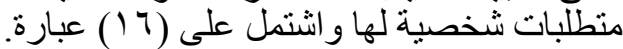

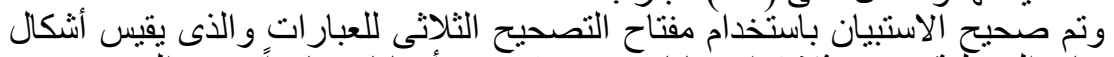

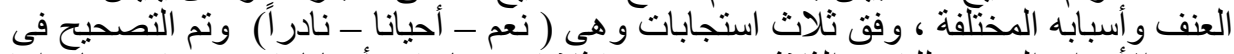

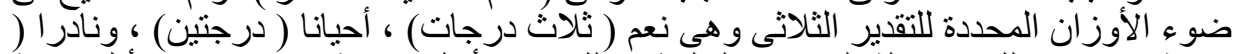

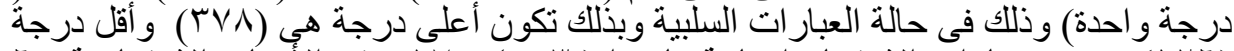

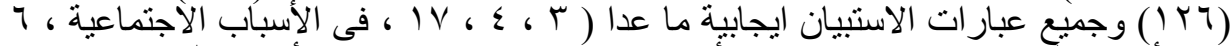

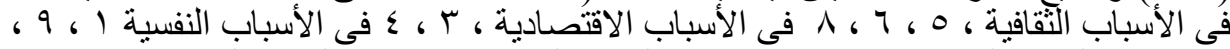

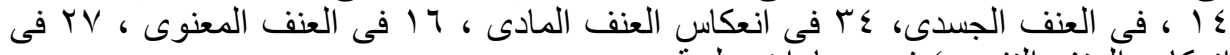

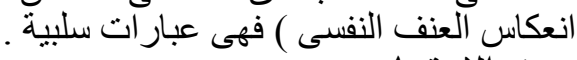

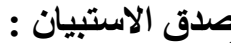
أ - أ - صدق المحتوى :

ويهدف إلى الحكم على مدى تمثيل الاستبيان للمحاور التى يقيسها ، ومدى مناسبة التئة

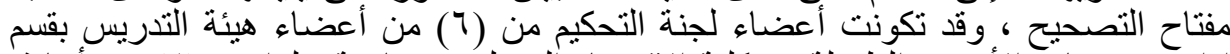

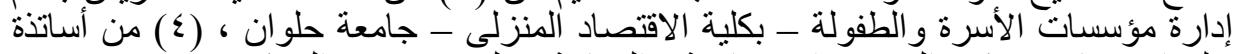

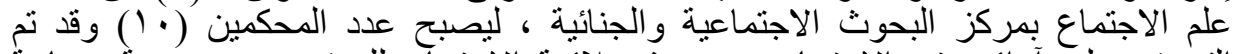

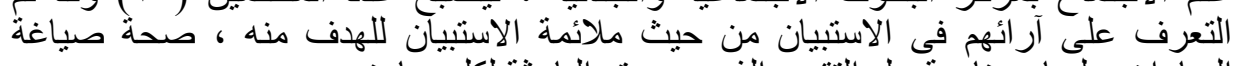

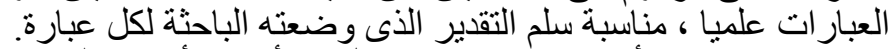

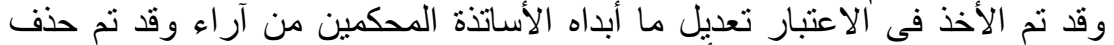

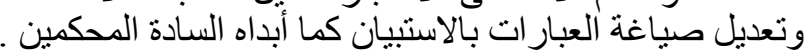
وتن حساب صدق الألى الاتساق الداخلى عن طريق حساب معامل الارتباط بين كل محور

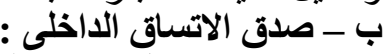

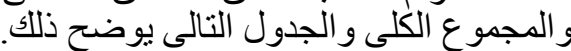

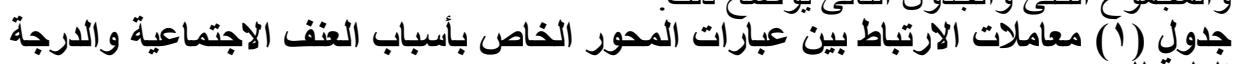

\begin{tabular}{|c|c|c|c|}
\hline الارتباط & الكعالة & 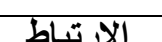 & 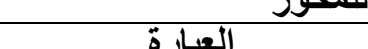 \\
\hline & & & أ - عنف بسبب الآجتماعبة \\
\hline$* * .9 .7$ & 11 & $* * . . V V Y$ & 1 \\
\hline$* * \cdot \wedge \cdot q$ & TY & $* * . \wedge V V$ & T \\
\hline **. . TYO & $\pi$ & **..9Y. & r \\
\hline$* * . \wedge V Y$ & $1 \leqslant$ & **. . 10r & $\varepsilon$ \\
\hline$* *, q, r$ & 10 & $* * .9 \mu \wedge$ & 0 \\
\hline **.VAr & 17 & & ب عنف بسبب سلو لك المر أة \\
\hline$* * . \wedge 9 \Gamma$ & IV & **,VYY & 1 \\
\hline 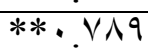 & 11 & **. . & $\mathrm{V}$ \\
\hline **. . АT & 19 & $* * . \wedge 0 \leqslant$ & $\Lambda$ \\
\hline **. . V9V & T. & $* * \ldots \vee \wedge \wedge$ & 9 \\
\hline **. VO & YI & **..ATr & 1 . \\
\hline
\end{tabular}




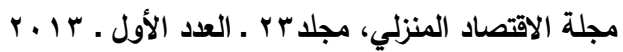

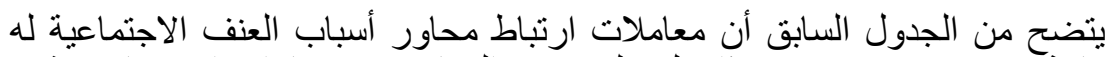

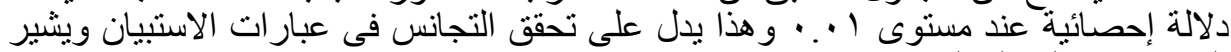
إلى الآتساق الذاخلى للاستبيان. جلولي (Y)معاملات الارتباط بين عبارات الذاتل المحور الخاص بأسباب العنف الاجتماعية والدرجة

\begin{tabular}{|c|c|c|c|}
\hline الارتباط & العبارة & الارتباط & العبارة \\
\hline$* * . . V \vee \varepsilon$ & $\mathrm{V}$ & & الأسباب النفافية \\
\hline \multirow[t]{2}{*}{$* * . . \wedge 07$} & $\Lambda$ & $* * \cdot . \Lambda \cdot V$ & 1 \\
\hline & الأسباب النفسية & $* * . . \wedge F r$ & r \\
\hline$* * . . V \otimes r$ & -1 & $* * . . \wedge \wedge V$ & $\mu$ \\
\hline$* * ., \Lambda \cdot 7$ & $-Y$ & $* * . . \wedge r q$ & $\varepsilon$ \\
\hline$* * . . \wedge 9 Y$ & $-r$ & $* * . . \vee \diamond \wedge$ & 0 \\
\hline$* * . . \wedge T V$ & $-\varepsilon$ & $* * . . \wedge 79$ & 7 \\
\hline$* * . . \vee V 1$ & -0 & $* * . . \vee 9$. & $\mathrm{V}$ \\
\hline$* * . V R r$ & -7 & & الأسباب الاقتصادى \\
\hline$* * . . \wedge \otimes r$ & $-V$ & $* * . .919$ & $T$ \\
\hline 0 & -1 & $* * . . \vee \wedge$. & r \\
\hline$* * \cdot . \vee \wedge \wedge$ & 9 & **..TrY & $\mu$ \\
\hline$* * . . \wedge \wedge$ & -1. & $* * . . \wedge \vee 7$ & $\varepsilon$ \\
\hline \multirow[t]{2}{*}{$* * . .9 \leqslant Y$} & -11 & $* * ., \Lambda \leq 0$ & 0 \\
\hline & & $* * . . \wedge r r$ & 7 \\
\hline
\end{tabular}

يتضح من الجدول السابق أن معاملات ارتباط محاور أسباب العنف العابه الثقافية

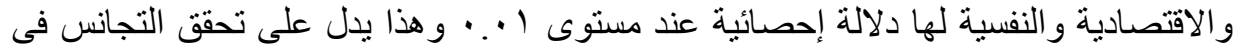

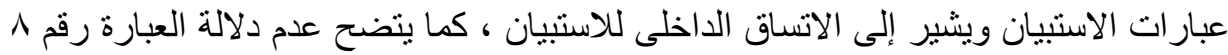

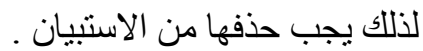

\begin{tabular}{|c|c|c|}
\hline مستوى الدلالة & معامل الارتباط & المحاور \\
\hline$\because+1$ & .901 & الأسباب الاجتماعية \\
\hline$\because \cdot 1$ & $\because$. $14 q$ & الاسباب الثُقافية \\
\hline$\because \cdot 1$ & $\because V 00$ & الأسباب الاقتصادية \\
\hline$\because \cdot 1$ & $\because \wedge \wedge \varepsilon$ & الأسباب النفسية \\
\hline$\because \cdot 1$ & $.94 \pi$ & المقياس ككل \\
\hline
\end{tabular}

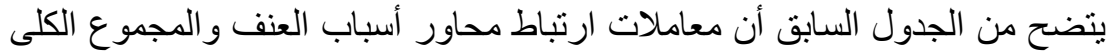

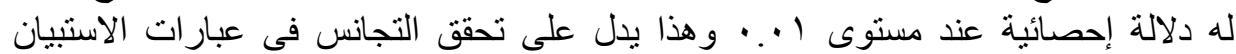
ويشير إلى الاتساق الداخلى للاستبيان. 


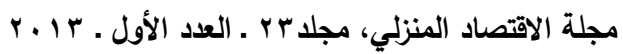

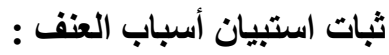
جذول ( ) )قيم معاملات الثبات بطرق ألفا كرونباخ والتجزئة النصفية وجيتومان

\begin{tabular}{|c|c|c|c|c|}
\hline جيتومان & سبير مان & تجزئة & ألفا & المحاور \\
\hline •.AAYT & .9470 & . & $\cdot .91 \leqslant 1$ & الأسباب الاجتماعية \\
\hline 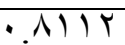 & $\therefore \wedge 1990$ & $\cdot . \wedge \cdot 1 \cdot$ & $\because \vee \wedge 09$ & الأسباب الثقافية \\
\hline$\cdot . \wedge V \leqslant V$ & .97 .4 & $.9 Y T 7$ & $\cdot .9 r \mid \leqslant$ & الأسباب الاقتصادية \\
\hline $.9 \ldots 1$ & $.90 \mathrm{YA}$ & .9 .99 & •.ATIV & الأسباب النفسية \\
\hline$\cdot \Delta r \cdot \Lambda$ & $\cdot . \wedge \leqslant Y \tau$ & $\because \vee Y 90$ & $\therefore(1911$ & أسباب العنف ككل \\
\hline
\end{tabular}
حساب الثبات وتعتبر هذه القيمة عالية ، و هذا دليل على ثنات الثبات هذا الجز ع من الاستبيان.

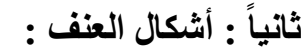
جدول (•) معاملات الارتباط بين عبارات المحور الخاص بالعنف المادى والدرجة الكلية

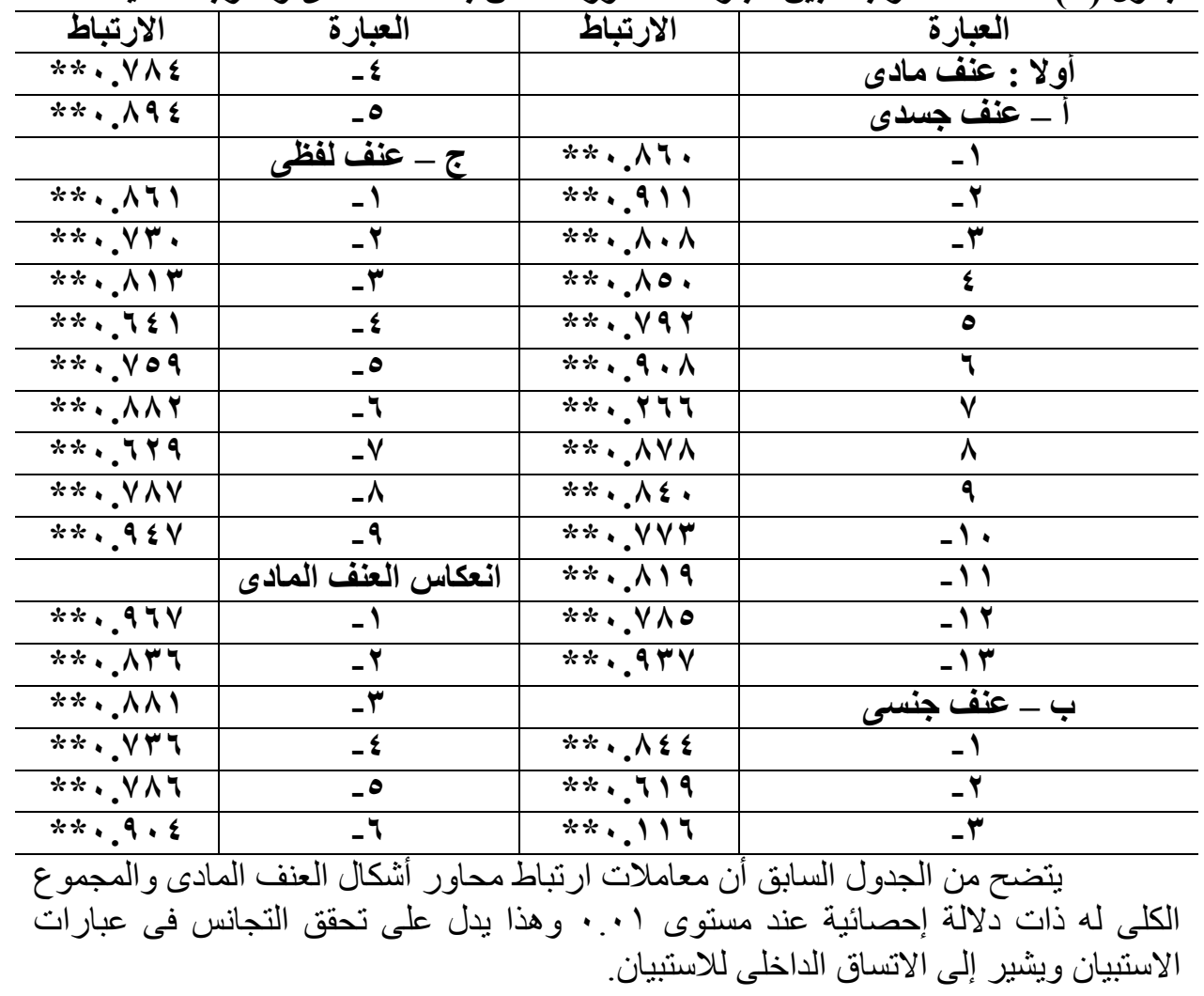




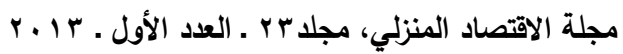

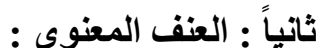
جذول (†) معاملات الارتباط بين عبارات المحور الخاص بالعنف المعنوى والدرجة الكلية

\begin{tabular}{|c|c|c|c|}
\hline الارتباط & العبارة & الارتباط & العبارة \\
\hline. .579 & -17 & & ثُانيا : العنف المعنوى \\
\hline \multirow[t]{2}{*}{$* * ., \Lambda Y \varepsilon$} & $-1 V$ & $* * . \Lambda 1 Y$ & -1 \\
\hline & انعكاس العنف المعنوى & $* * \cdot . \wedge \vee \leq$ & -4 \\
\hline$* * \cdot V \cdot 1$ & $-1 \wedge$ & $* *, 7,9$ & $-\mu$ \\
\hline$* * \cdot . \wedge r r$ & -19 & $* * . . \vee 9 \%$ & $\varepsilon$ \\
\hline$* * \cdot .940$ & $-r$. & $* * ., \Lambda \cdot 0$ & 0 \\
\hline$* * \cdot . \wedge \cdot r$ & $-Y_{1}$ & $* * . .9 r 1$ & 7 \\
\hline$* * \cdot .7 \wedge V$ & -YY & $* * \cdot . \wedge \cdots$ & $\mathrm{V}$ \\
\hline$* * \cdot . \wedge V 1$ & -TT & $* * \cdot .9 \leqslant 1$ & $\Lambda$ \\
\hline$* * \cdot . \vee \wedge r$ & $-r \leqslant$ & $* * . .7 \mathrm{rV}$ & 9 \\
\hline$* * .971$ & $-Y O$ & $* * . . \vee 7 \wedge$ & -1 \\
\hline$* * . .7 r \wedge$ & $-T^{-}$ & $* * . .7 \vee 0$ & -11 \\
\hline$* * . .799$ & $-4 V$ & $* * . . \vee \wedge 1$ & -14 \\
\hline$* * . . \wedge 0 \mathrm{~V}$ & $-Y \Lambda$ & $* * . . \wedge \vee q$ & -14 \\
\hline \multirow[t]{2}{*}{$* * \cdot . \vee Y q$} & $-r q$ & $* *, . V \odot V$ & $-1 \leqslant$ \\
\hline & & $* * . . \vee q$. & -10 \\
\hline
\end{tabular}

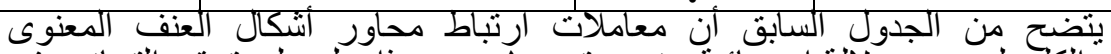

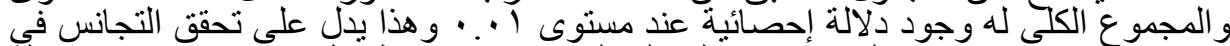

عبار ات الاستبيان ويشبر إلى الاتساق الداخلى للاستبيان ، وهنالك العبارة رقم 17 غير لالير دالة

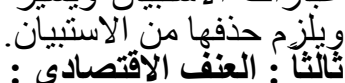

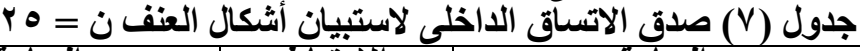

\begin{tabular}{|c|c|c|c|}
\hline الارتباط & العبارة & الارثباط & لعبارة \\
\hline$* * .9 T r$ & -9 & $* * . \Lambda \varepsilon \Lambda$ & -1 \\
\hline$* * ., \wedge \leq Y$ & -1. & $* *$ *.AYT & $-Y$ \\
\hline$* *$. VTV & -11 & $* * . .97$. & $-r$ \\
\hline$* * . . \Lambda 1$. & -14 & $* * . . V \leq \Gamma$ & $\varepsilon$ \\
\hline **..人ฯ & $-1 \pi$ & $* * . . \wedge q$. & 0 \\
\hline$* *, \wedge Y$. & $-1 \leqslant$ & $* * . . \wedge Y V$ & 7 \\
\hline$* * . .797$ & -10 & $* * . \vee \vee q \leq$ & v \\
\hline$* * . V \Gamma \wedge$ & -17 & $* * . .710$ & $\Lambda$ \\
\hline
\end{tabular}

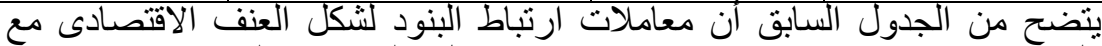

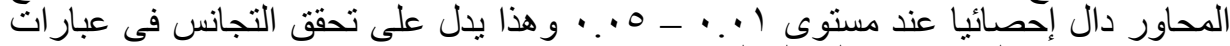
الاستبيان ويشير إلى الاتساق الداخلى للاستبيان. 


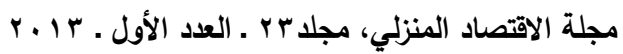

\begin{tabular}{|c|c|c|}
\hline مستوى الدلالة & معامل الارتباط & المحاور \\
\hline$\because+1$ & $\cdot .9 \vee 7$ & العنف المادى \\
\hline$\because+1$ & $\because .110$ & العنف النفسىى \\
\hline$\because+1$ & $\because \wedge 9 \wedge$ & العنف الإتتصادى \\
\hline$\because .1$ & $\because 9 \leqslant 0$ & أشكال العنف ككل \\
\hline
\end{tabular}

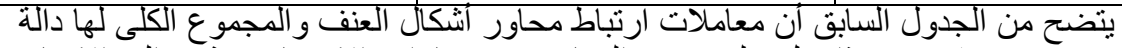

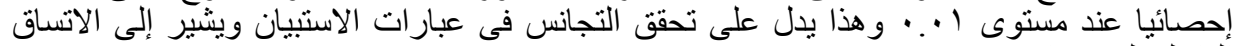

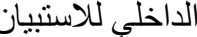

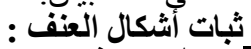
جذول (9)ثبات استبيان أشكال العنف

\begin{tabular}{|c|c|c|c|c|}
\hline جيتومان & سبيرمان & تجزئة & ألفا & المحاور \\
\hline .91149 &. .9101 & $\cdot . \wedge \leq \leqslant V$ &. $.9 \mathrm{NV \Lambda}$ & العنف المادى \\
\hline$\cdot .1199$ &. .1199 & $\cdot .79 \leqslant V$ & $\cdot . A \cdot T V$ & العنف النفسى \\
\hline$\cdot .940 \%$ & $\cdot .9 \leqslant \cdot 1$ & $\cdot . \wedge \wedge \wedge 1$ & $. .9 \leq 01$ & العنف الاقتصادى \\
\hline$\because . \wedge \vee 97$ & $\cdot . \wedge \Lambda Y \wedge$ & $\cdot . \vee q+r$ & $\cdot$. AVY. & أشكال العنف ككل \\
\hline
\end{tabular}

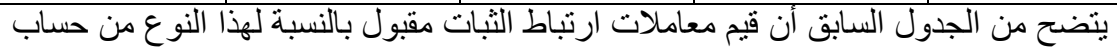

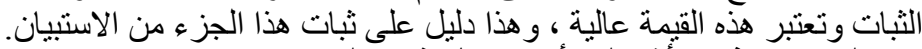

\begin{tabular}{|c|c|c|c|c|}
\hline ר" & 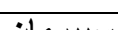 & 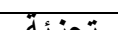 & 10ाi & ألمحاهر \\
\hline.$\wedge 99 \mathrm{~V}$ &.$\wedge 9 \wedge 9$ & $.117 \varepsilon$ &.$\widehat{\wedge \wedge \Lambda}$. & أسباب وأشكالَ العنف \\
\hline
\end{tabular}

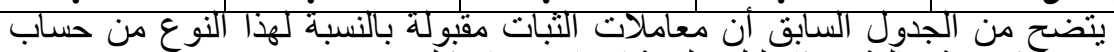

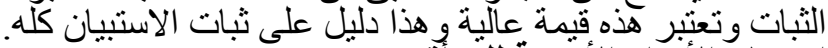

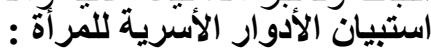

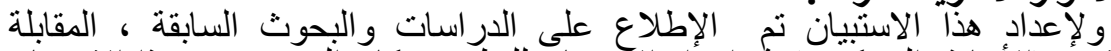

الثخصية مع (الأساتذة المحكمين) ثم إعداد الأستبيان للتطبيق وكان الإنغ النغرض من هذا الاستبيان

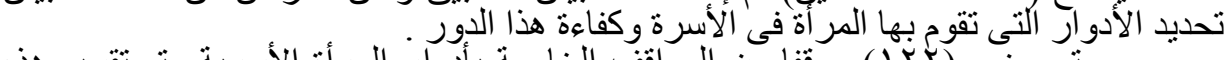

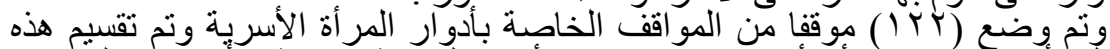

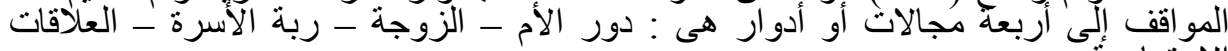
الاجنماعية.

الالدز الأولّ : دور الأم : وهو الدور الذى تقوم الأم من خلاله بالاهتمام وتربية الأبناء اجتماعيا

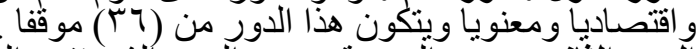

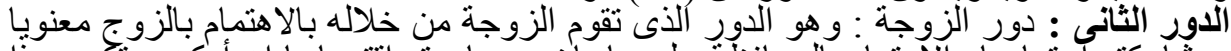

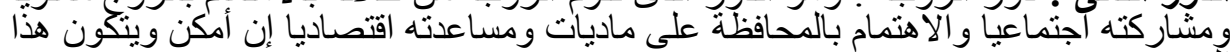

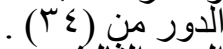

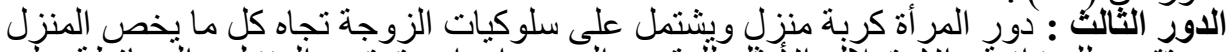

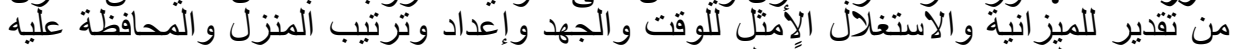

مو اقف خاصة بالميز انبة المالية

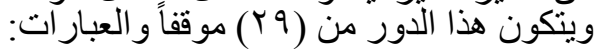

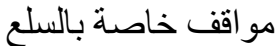

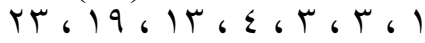
مو اقف خاصة بميز انية الوقت باصن

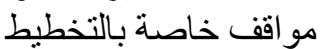
$r 76 \Lambda$ مو اقف خاصة بتر شيد الاستخهلاك $1061 Y, 1161.69$

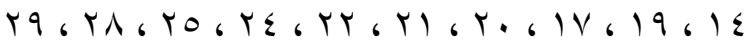
$r V \cdot 11$ 


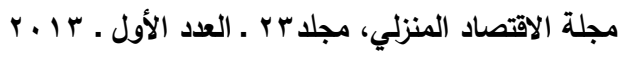

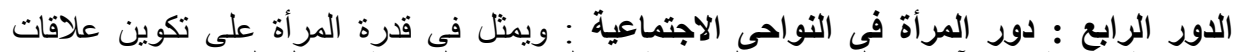

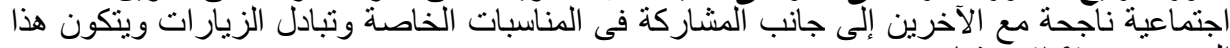

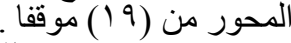

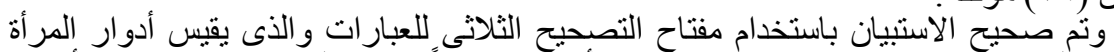

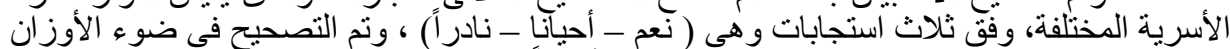

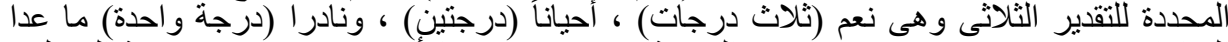

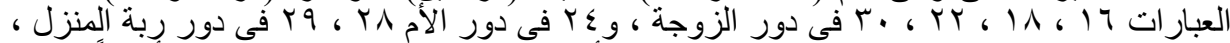

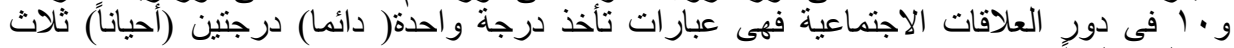

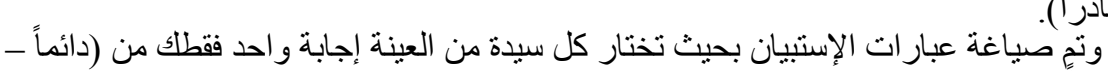
درجات (نادرا) أحياناً - نادر أ).

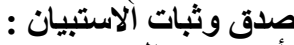
أ أ ) صدق المحتوى : تم عرض الاستبيان على مجموعة من الأساتذة المحكمين فى كلية الاقتصاد المنزلى ومركز

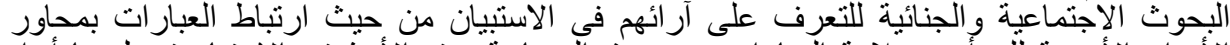

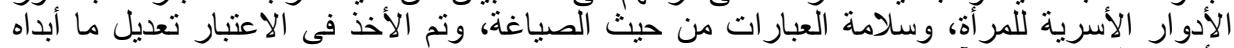

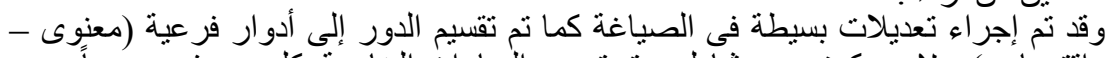

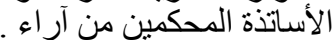

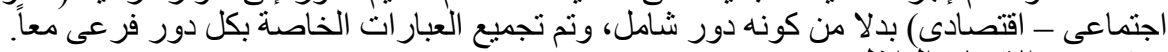

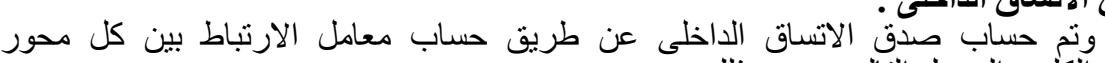

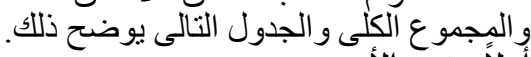

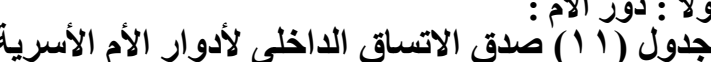

\begin{tabular}{|c|c|c|c|}
\hline الارتباط & العبارة & الارتباط & اللعبارة \\
\hline$* * . . \vee 0$. & 11 & & أولا : دور الام \\
\hline$* * ., 7 \wedge r$ & 19 & & أ ـ المعنوى \\
\hline$* . .7 \mathrm{~V}$ & Y. &..$\vee 91$ & 1 \\
\hline$* * . . \vee \ldots$ & YI & $* * .97 \leqslant$ & r \\
\hline$* * . . \vee 74$ & YY & $\cdot \wedge \vee$ & $r$ \\
\hline$* * . \wedge r$. & YT & $* * . .747$ & $\varepsilon$ \\
\hline$* * .90 \%$ & $Y \leqslant$ & $* * . \wedge 00$ & 0 \\
\hline$* * . V \backslash V$ & YO & $* * .77 \varepsilon$ & 7 \\
\hline \multirow[t]{2}{*}{$* \% . \vee \vee 94$} & Yq & $* * . . V \vee V$ & $\mathrm{~V}$ \\
\hline & ج - الاقتصادى & $* * .7 .0$ & $\Lambda$ \\
\hline$* * . .9 \leqslant \Lambda$ & TV & $* * . \wedge \Gamma \xi$ & 9 \\
\hline$* * . .197$ & YN & $* . .7 \leqslant T$ & 1. \\
\hline$* * ., \Lambda Y Y$ & Yq & $* * . \wedge \wedge q$ & 11 \\
\hline$* *$. *V9 & $r \cdot$ & $* * .7 V 7$ & Ir \\
\hline$* * . \wedge \vee 0$ & Tा & & ب - الاجتماعى \\
\hline$* * .9 Y 7$ & TY & $* * . V T V$ & IT \\
\hline$* \% .794$ & Tr & $* * . \wedge 0 \wedge$ & $1 \varepsilon$ \\
\hline$* . . T \%$ & एद & $* * .9 V$. & 10 \\
\hline \multirow[t]{2}{*}{$* * . \wedge 0 q$} & ry & $* * ., \wedge \leqslant \Gamma$ & 17 \\
\hline & & $* * ., \Lambda I V$ & IV \\
\hline
\end{tabular}




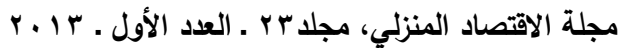

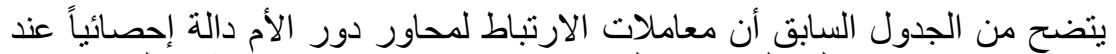

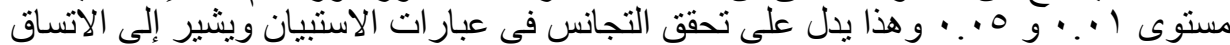

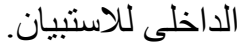

جدول (r ا (الآتساق الداخلى لأدوار الأم مع الدرجة الكلية

\begin{tabular}{|c|c|}
\hline الارثباط & العبارة \\
\hline$* * .9 \% q$ & الالدور المعنوى \\
\hline$* *, \Delta Y I$ & اللور الاجتماعى \\
\hline$* * . . V \Psi \varepsilon$ & الأور الاقتصادى \\
\hline
\end{tabular}

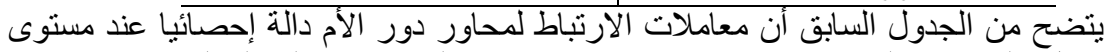

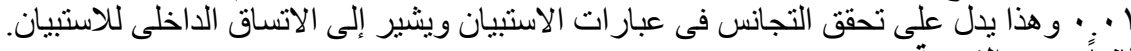

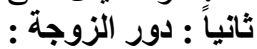

\begin{tabular}{|c|c|c|c|}
\hline الارتباط & العبارة & الارتباط & العبارة \\
\hline$* * \cdot .90 \leqslant$ & -19 & & ثُانيا : دور الزوجة \\
\hline$* * \cdot . V \cdot q$ & $-r$. & & أ - المعنوى \\
\hline$* * . .7 Y 1$ & $-Y_{1}$ & $* *, \wedge 01$ & -1 \\
\hline$* * \cdot . \wedge \cdot 1$ & -YY & $* * . \wedge T 0$ & $r$ \\
\hline$* * . V Y \wedge$ & - & $* * . .7 \Lambda \leqslant$ & -r \\
\hline$* * . . V \Psi 1$ & $-Y \xi$ & $* * . .90$. & $-\xi$ \\
\hline$* * \cdot . \wedge 1 \wedge$ & -YO & $* . .711$ & -0 \\
\hline$* * .977$ & $-Y Y$ & $* * . . \wedge \wedge \neg$ & -7 \\
\hline$* * . .711$ & $-Y V$ & $* . . \wedge 9$. & $-V$ \\
\hline$* * \cdot . V Y$. & $-r \Lambda$ & $* * \cdot . \vee \vee \wedge$ & $-\Lambda$ \\
\hline$* * .947$ & $-4 q$ & $* * \cdot .9 \cdot v$ & -9 \\
\hline \multirow[t]{2}{*}{$* * . . \vee 01$} & -r. & $* * . \wedge 11$ & -1 \\
\hline & ج - اقتصادى & $* * \cdot V \otimes r$ & -11 \\
\hline$* * \cdot . \wedge \cdot Y$ & $-r_{1}$ & $* . .7 \mathrm{YV}$ & -14 \\
\hline$* * .9 \leq 7$ & - MY & $* * \cdot . \wedge \leq V$ & -14 \\
\hline$* * . \vee \backslash \backslash 7$ & - & $* * . .7 V$. & $-1 \leq$ \\
\hline$* * . .7 \% 0$ & $-r \leq$ & $* * . .909$ & -10 \\
\hline$* * . .790$ & - ro & $* * . .7 \leqslant 7$ & -17 \\
\hline$* * \cdot . \wedge Y \Lambda$ & $-r q$ & & ب - اجتماعى \\
\hline \multirow[t]{2}{*}{$* * \cdot . V V V$} & $-r V$ & $* * . . \vee \wedge 1$ & IV \\
\hline & & $* * . .79$. & -11 \\
\hline
\end{tabular}

جدول ( ا ) الاتساق الداخلى لأدوار الزوجة مع الدرجة الكلية

\begin{tabular}{|c|c|}
\hline الارتباط & العبارة \\
\hline$* * .9 \varepsilon \varepsilon$ & الأور المعنوى \\
\hline$* * . .199$ & الدور الاجتماعى \\
\hline$* * . . \vee 70$ & الاور الاقتصـادى \\
\hline
\end{tabular}




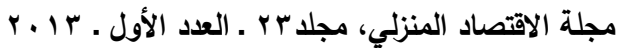

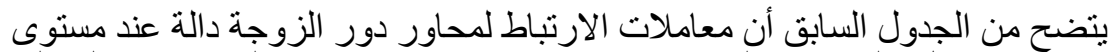

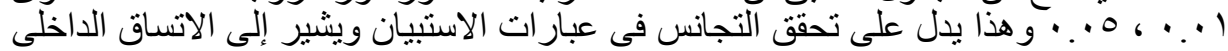

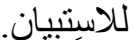

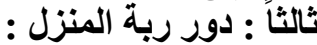

جدول (0 1 ) الاتساق الداخلى لداور المرأة كربة منزل البند مع المحاور

\begin{tabular}{|c|c|c|c|}
\hline الارتباط & العبارة & الارتباط & العبارة \\
\hline$* * . \wedge 01$ & -17 & $* * . . \vee 10$ & -1 \\
\hline$* * . . \vee 90$ & $-1 V$ & $* * . . \wedge \wedge q$ & $-Y$ \\
\hline$* *, . \wedge \leq 0$ & -11 & $* * . \wedge \vee \neg$ & $-r$ \\
\hline$* *, .900$ & -19 & $* * . .79 \varepsilon$ & $-\varepsilon$ \\
\hline$* *, . V \leqslant Y$ & $-Y$. & $* * . .7 \mu$ & -0 \\
\hline$* * . . \vee 7$. & $-Y I$ & $* * \cdot .9 \cdot 1$ & -7 \\
\hline$* * . . \wedge 90$ & $-Y Y$ & $* * . .791$ & $-V$ \\
\hline$* * . .7 \vee 9$ & $-Y \mu$ & $* * .9 \leq 9$ & $-\Lambda$ \\
\hline$* * . .7 \leq V$ & $-Y \varepsilon$ & $* *, . \vee Y 0$ & -9 \\
\hline$* *, . V \vee 0$ & $-Y O$ & **... I & -1. \\
\hline$* * . .917$ & $-Y Y$ & $* * . . \vee \wedge V$ & -11 \\
\hline$* * . . \wedge 91$ & $-Y V$ & $* * . . V 7 \mu$ & $-1 Y$ \\
\hline$* *, . \vee \backslash \wedge$ & $-Y \Lambda$ & $* * \cdot V \cdot V$ & -14 \\
\hline \multirow[t]{2}{*}{$* *, . \vee 7 \varepsilon$} & $-r q$ & $* * . .7 Y \varepsilon$ & $-1 \varepsilon$ \\
\hline & & $* * . .7 V T$ & -10 \\
\hline
\end{tabular}

يتضح من الجدول السابق أن معاملات الارتباط لبنود دور ربة الأسرة مع المحور

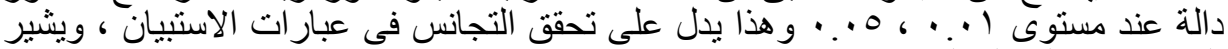

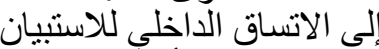

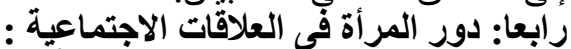

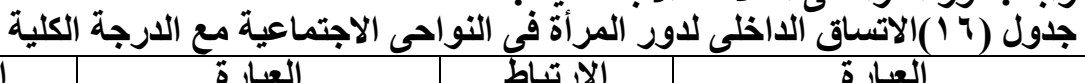

\begin{tabular}{|c|c|c|c|}
\hline الارتباط & العبارة & الارتباط & العبارة \\
\hline$* * . .97 Y$ & -11 & $* * . V I Y$ & -1 \\
\hline$* * \cdot . V \cdot \theta$ & $-1 Y$ & $* * . .9 \ldots$ & $-Y$ \\
\hline$* * . .791$ & $-1 \pi$ & $* * . . \wedge \vee \varepsilon$ & $-\mu$ \\
\hline$-\cdot .7 \cdot V$ & $-1 \leqslant$ & $* * . .7 \varepsilon$. & $-\varepsilon$ \\
\hline$* * . .91 \wedge$ & -10 & $* * . . V V Y$ & -0 \\
\hline$* * . . \otimes \vee \neg$ & -17 & $* * . .9 \leqslant r$ & -7 \\
\hline$* * \cdot . \wedge \wedge 1$ & $-1 V$ & $* * . . \vee 19$ & $-V$ \\
\hline$* * . .90 Y$ & -11 & $* * . . \wedge \neg \wedge$ & $-\Lambda$ \\
\hline \multirow[t]{2}{*}{$* * \cdot . \wedge 1 \leqslant$} & -19 & $* * . .879$ & -9 \\
\hline & & . IYY & -1 . \\
\hline
\end{tabular}

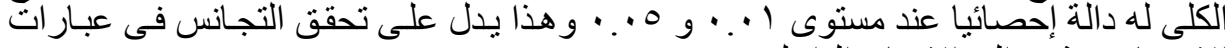
الاستبيان ويشير إلى الاتساق الداخلى الدانى 


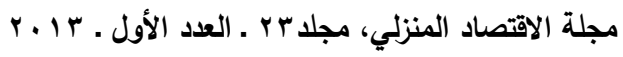

جدول ( V Vصدق الاتساق الداخلى لاستبيان أدوار المرأة الأسرية

\begin{tabular}{|c|c|c|}
\hline مستوى اللالالة & معامل الارتباط & المحاور \\
\hline$\because \cdot 1$ & $\cdot . \wedge 91$ & ل مل دور الأم \\
\hline$\because \cdot 1$ & $\cdot . \wedge \cdot \varepsilon$ & لدور الزوجة \\
\hline$\because \cdot 1$ & $\therefore \wedge \Delta 0$ & دور ربة المنزل \\
\hline$\because \cdot 1$ & .994 & تكوين علاقّات اجتماعيةٌ ناجحة \\
\hline
\end{tabular}

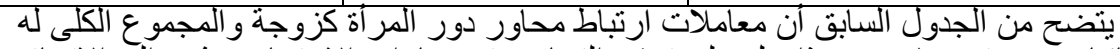

دالة إحصائيا عند مستوى 1 . . و وهذا يدل على تحقق التجانس فى عبار ات الاستبيان ويشير إلى الاتساق

\begin{tabular}{|c|c|c|c|c|}
\hline جيتومان & سبيرمان & تجزئة & 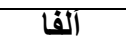 & العبارةة \\
\hline$\cdot . \wedge Y q \wedge$ & $\cdot .9+11$ & . AYIT & • & العنف أمغنوى \\
\hline$\cdot V \leqslant \mu 1$ & $\because V 9 V V$ & - & $\because$ VYVO & العنف النفسى \\
\hline •.AYVI & ( & $\because$ V०V & $\cdot \wedge \leqslant 1 \wedge$ & العنف الاقتتصادى \\
\hline
\end{tabular}

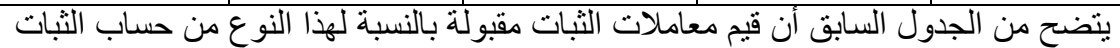

وتعتبر هذه القيمة عالية و هذا دليل على ثنبات هذا الجز اء من الاستبيان.

\begin{tabular}{|c|c|c|c|c|}
\hline \multicolumn{5}{|c|}{ جدول (9 1) تبات دور الزوجه } \\
\hline جيتومان & سبيرمان & تجزئة & ألفا & العيارة: \\
\hline .9117 & $.94 \leqslant r$ & .1 . 1970 & $.9 \cdot 7$ & العنف ألمعنوى \\
\hline..$\wedge 791$ & $. .19 \times 9$ & $\cdot . \Lambda \cdot \Lambda Y$ & $\because \wedge 09 \wedge$ & العنف النفسم \\
\hline.$\wedge \Gamma V I$ &.$\wedge V V Y$ & $. V \wedge \mid \mu$ & . AYqY & العنف الاقتصادى \\
\hline
\end{tabular}

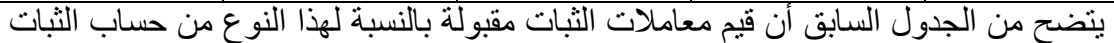

وتعتبر هذه القيمة عالية وهذا دليل على ثلبات هذا الجز الجاء من الاستيبيان.

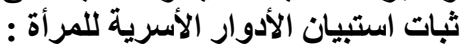

\begin{tabular}{|c|c|c|c|c|}
\hline جيتومان & سبيزممان & تجزئه & Tा & 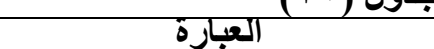 \\
\hline $.90 \% 9$ &. $.904 \xi$ & .974 &. $.991 \mathrm{~N}$ & لدور الام \\
\hline$\because$ VVq & $\because$. $P$ L $\varepsilon$ & $\because V 101$ & $\because$ VTVT & دور آلزوجها \\
\hline $.9 \varepsilon+1$ & $\because .9 \leqslant 0 \mathrm{~V}$ & $\cdot .19 \mathrm{VI}$ & .9199 & دور ربها المنْزَل \\
\hline$\because 9+7 \varepsilon$ & .9110 & $\cdot . \Lambda \varepsilon \cdot \Lambda$ &. . 999 & تكوين علافقات اجتماعيه ناجحه \\
\hline$\because v 1.9$ & $\because \wedge \leqslant \leqslant q$ & $\because$ VTा. & $\because V \cdot \varepsilon \Lambda$ & الادوار ككل " الادك \\
\hline
\end{tabular}

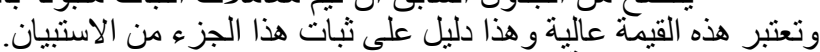

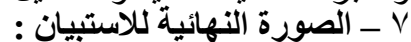

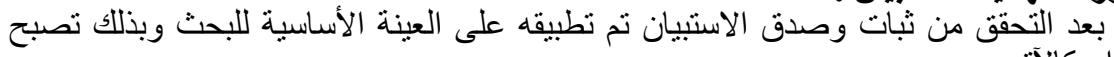

\begin{tabular}{|c|c|c|c|c|c|c|c|}
\hline أعلى درجة & 1.0 & $=$ & r & $x$ & ס & $=$ & دور الام \\
\hline قل در & ro & $=$ & 1 & $x$ & ro & $=$ & \\
\hline آعلى & 111 & $=$ & 1 & $x$ & rv & $=$ & دور الزوجة \\
\hline & TV & $=$ & 1 & $x$ & rV & $=$ & \\
\hline 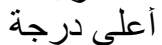 & AV & $=$ & r & $x$ & rq & $=$ & دور ربة المنزل \\
\hline أقل در حة & rq & $=$ & 1 & $x$ & rq & $=$ & \\
\hline على در & ov & $=$ & r & $x$ & 19 & $=$ & تكوين علاقات اجتماعية ناجحة \\
\hline 1 & 19 & $=$ & 1 & $x$ & 19 & $=$ & \\
\hline
\end{tabular}




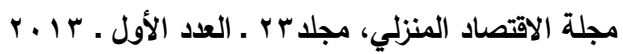

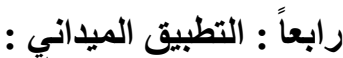

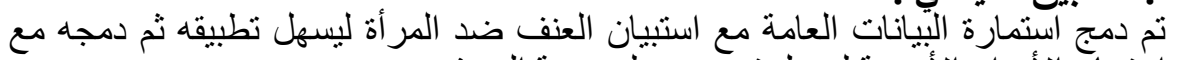

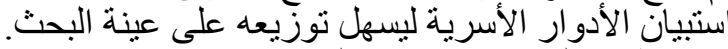

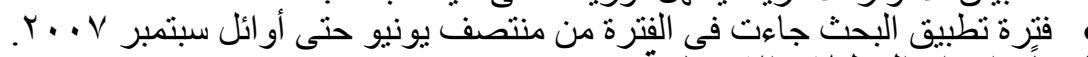

خامساً : إجراء التحليلات الإحصائية :

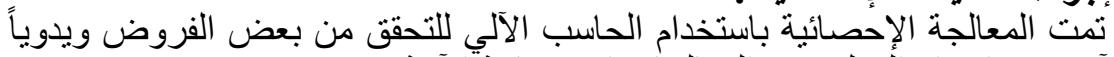

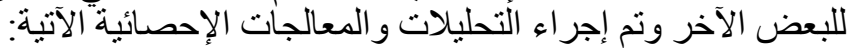

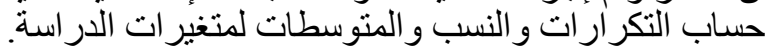

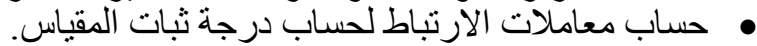

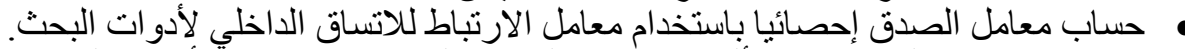

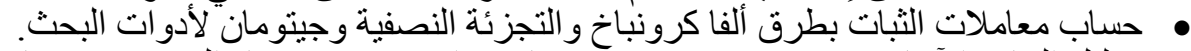

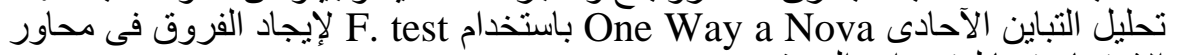

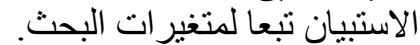

•

مصفوفة الارتباط لإيجاد العلاقة بين المتغيرات.

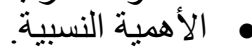

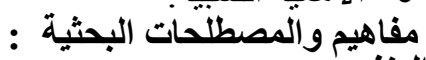

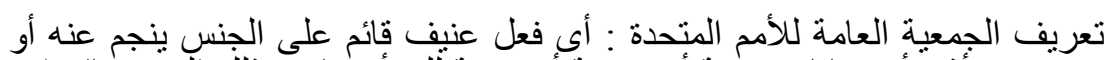

العنف: إنيم

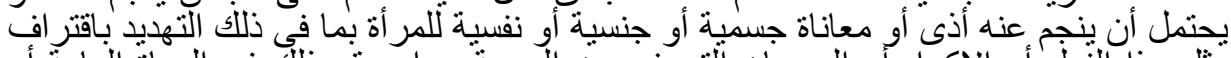

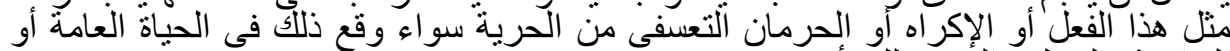

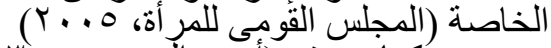

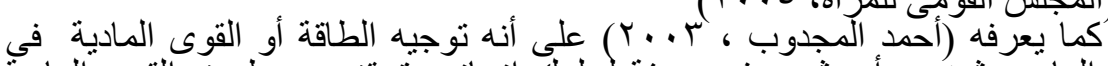

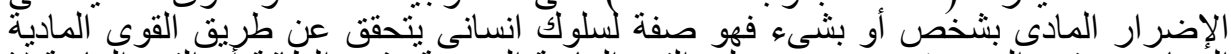

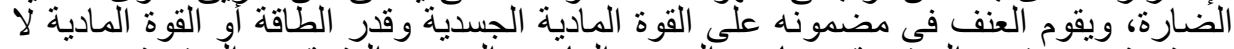

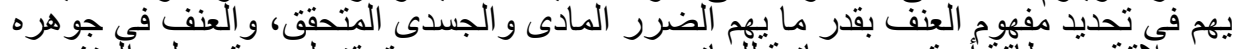

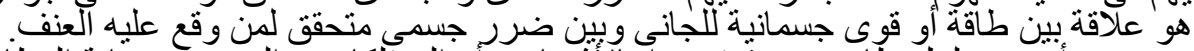

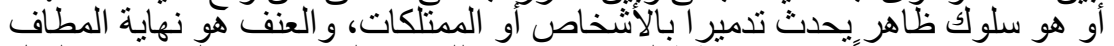

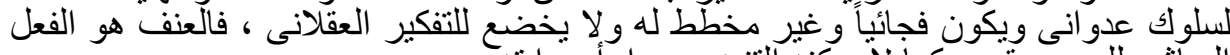

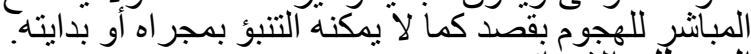

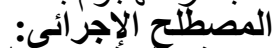

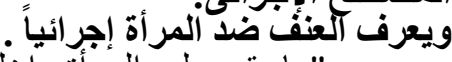

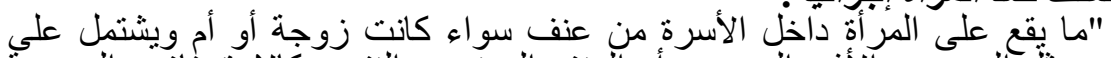

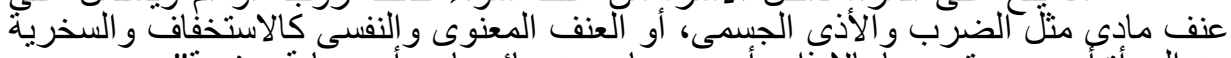

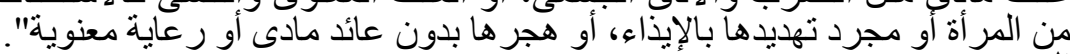

مجمو عة العادات والمبادىء والقيم التى يسير عليها الفرد ويتبعها فى سلوكه وفى

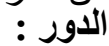

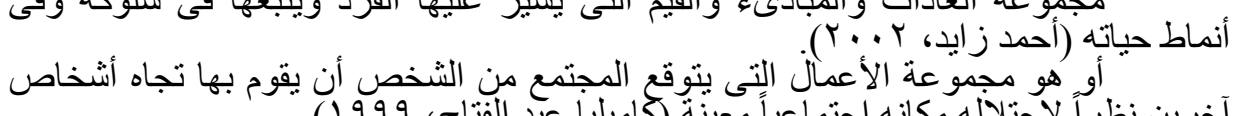

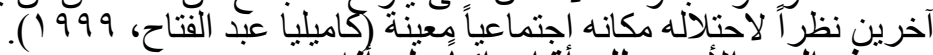

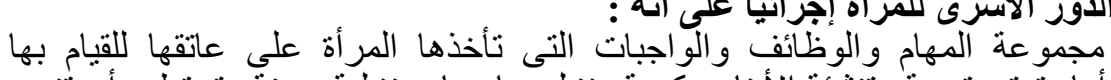

ويعرف الذور الأسرى للمراة إجرائيا على أنها :

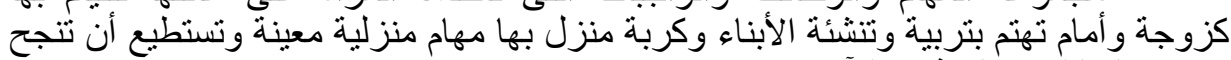
فى علاقاتها الاجتماعية مع الآخرين. 


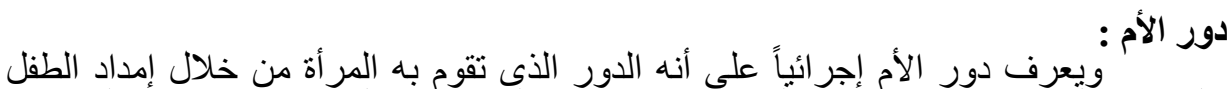

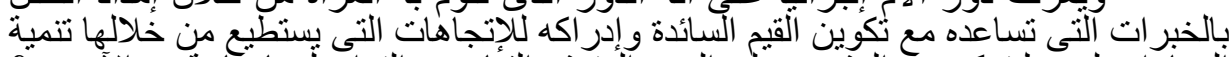

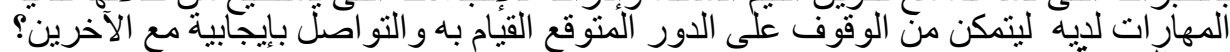

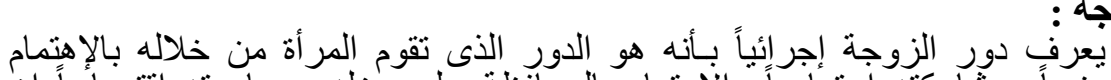

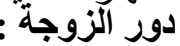

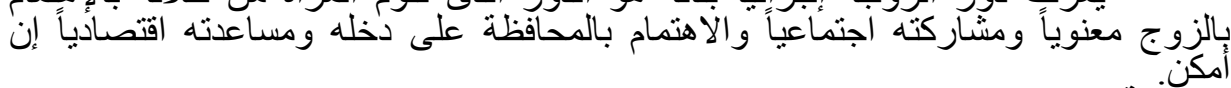

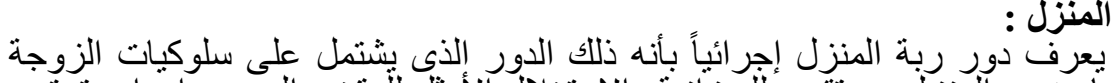

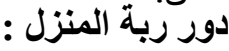

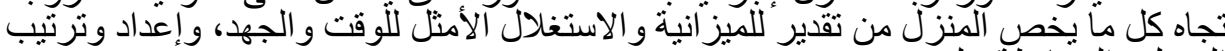

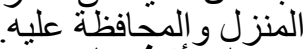
دور المرأة في النواحئئل الاجتماعية:

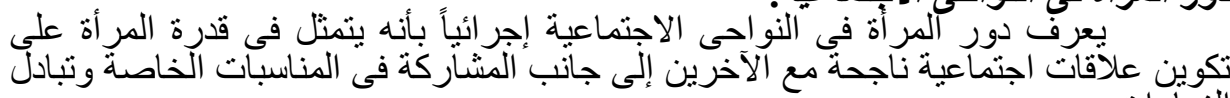

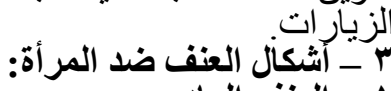

$$
\begin{aligned}
& 1 \text { ــ العنف المادى: }
\end{aligned}
$$

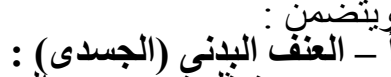

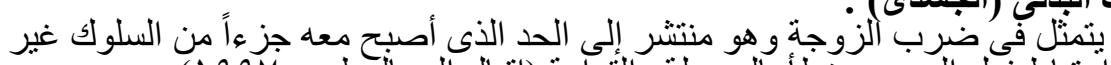

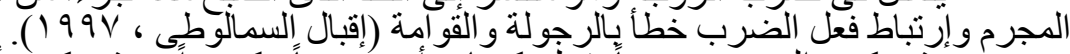

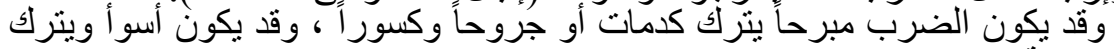

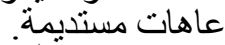

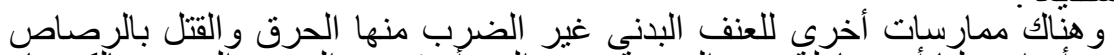

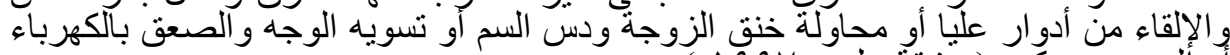

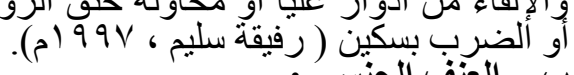

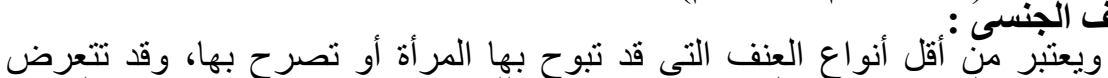

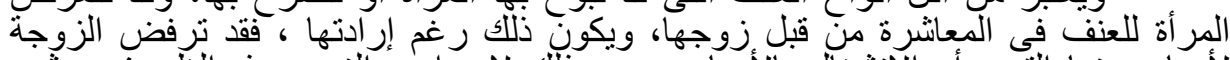

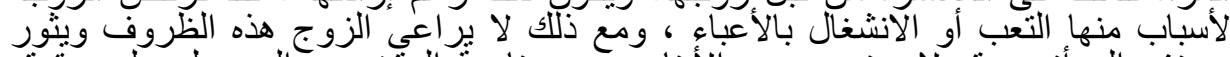

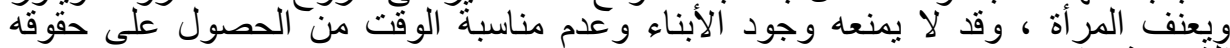

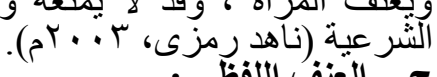

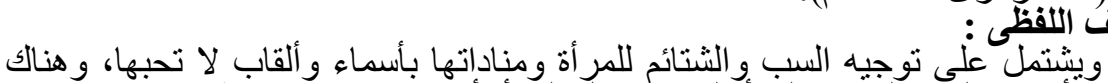

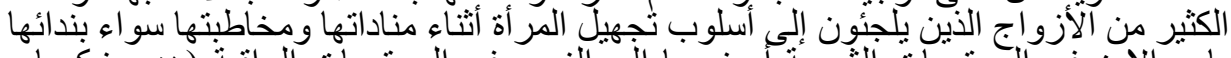

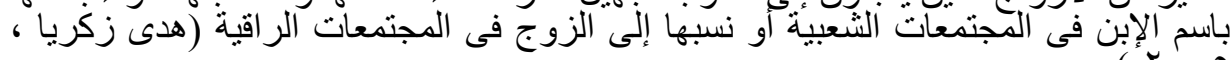

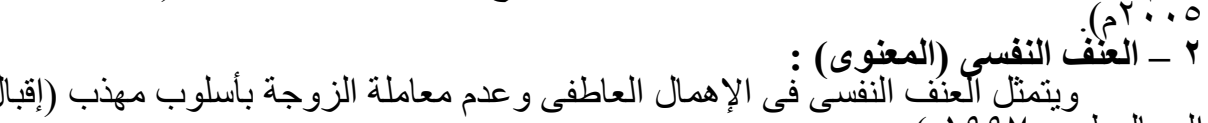

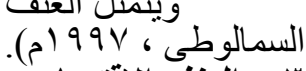

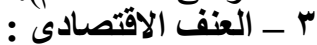

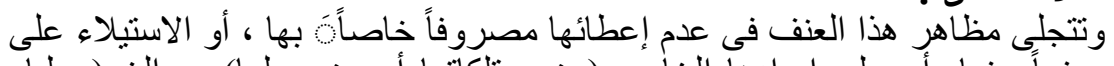

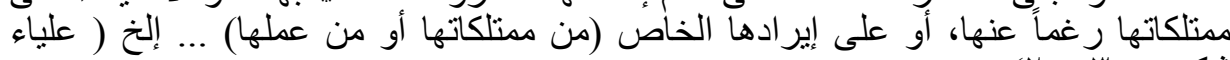

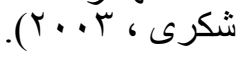




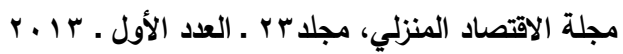

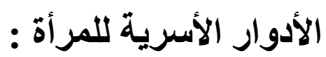

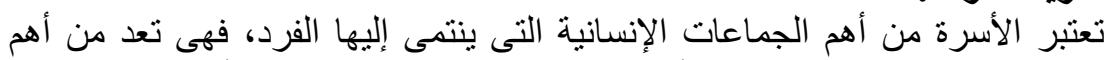

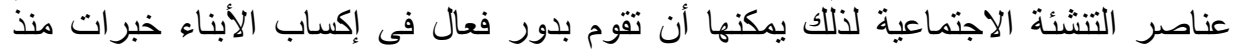

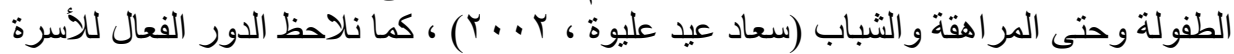

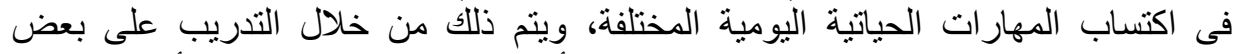

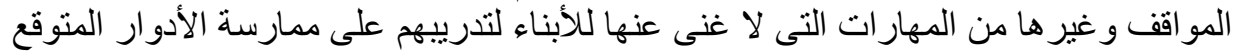

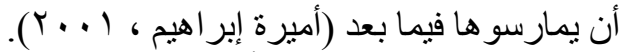

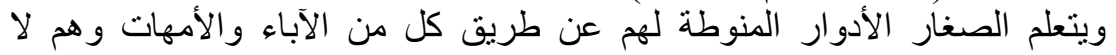

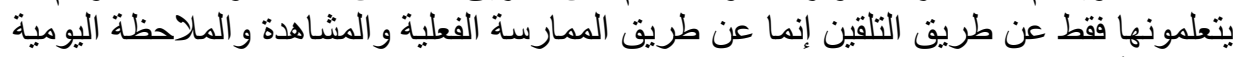

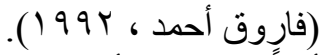

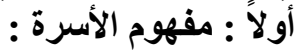

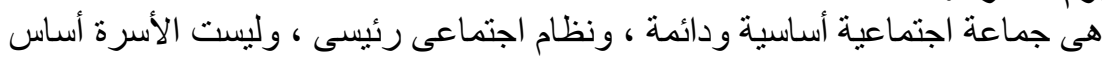

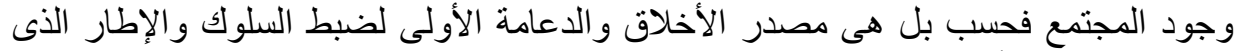

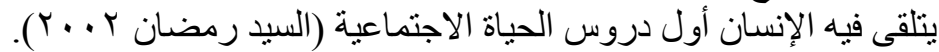

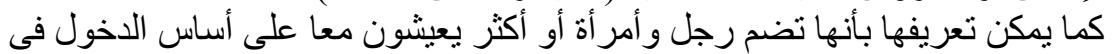

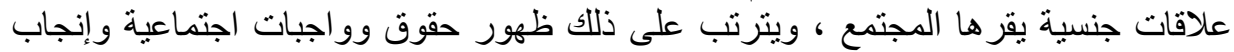

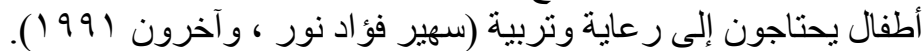

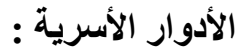

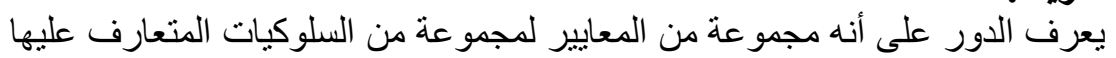

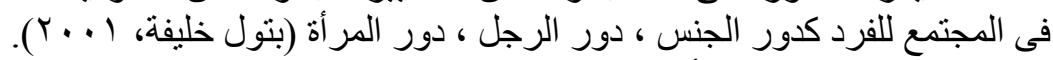

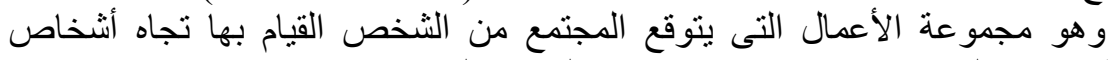

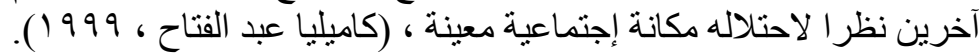

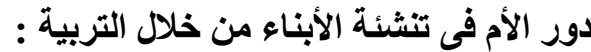

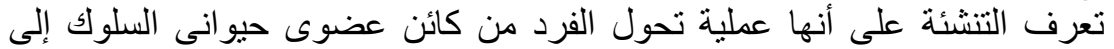

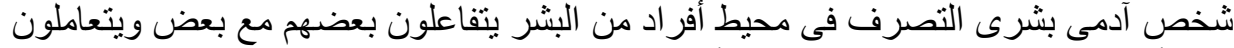

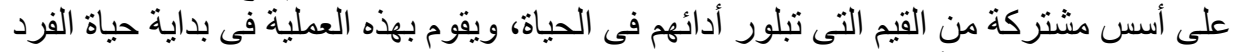

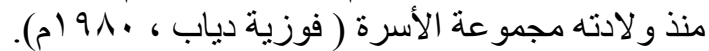

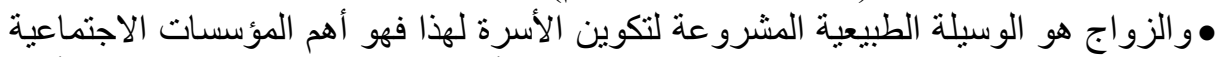

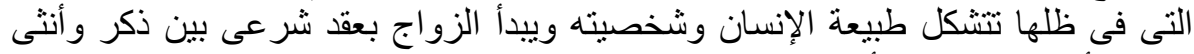

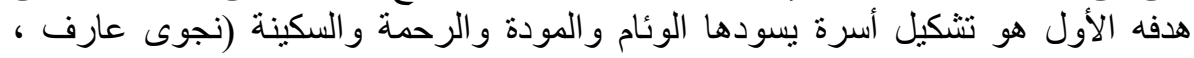

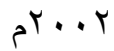

$$
\begin{aligned}
& \text { نتائج الدراسة الميدانية : }
\end{aligned}
$$

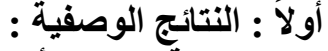

$$
\begin{aligned}
& \text { وصف عينة البحث الأساسية : } \\
& \text { وفيما يلى وصف لعينة البحث ( المر أة التى تعرضت للعنف) ، موضحة فى الجداول }
\end{aligned}
$$

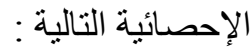




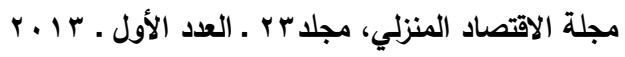

\begin{tabular}{|c|c|c|}
\hline النسبة 0/0 & التكرار & المستوى التعليمى للزوج \\
\hline$V .0$ & 9 & أمى \\
\hline 10.1 & 19 & يقرأ ويكتب \\
\hline $9 . r$ & 11 & ابتدائى \\
\hline $1 \cdot .1$ & 14 & متوسط \\
\hline 10 & 11 & ثانوى \\
\hline$r$ & rq & جامعى \\
\hline 11.8 & $1 \varepsilon$ & ماجستير ودكتوراه \\
\hline $1 \cdots$ & IY. & المجموع \\
\hline النسبة \% & التكرار & المستوى التعليمى للزوجة \\
\hline $1 \cdot .1$ & $1 r$ & أمى \\
\hline $1 \Lambda . r$ & rr & يقرأ ويكتب \\
\hline 1. & Ir & ابتدائى \\
\hline $1 Y .0$ & 10 & متوسط \\
\hline 10.1 & 19 & ثانوى \\
\hline ro & $r$. & جامعى \\
\hline$V .0$ & 9 & ماجستير ودكتوراه \\
\hline $1 \cdots$ & Ir. & المجموع \\
\hline النسبة \% & العدد & الاخل \\
\hline$\bullet . \wedge$ & 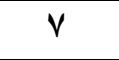 & 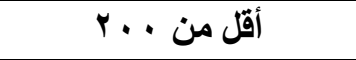 \\
\hline$\Lambda . r$ & $1 \cdot$ & 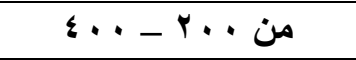 \\
\hline $1 Y .0$ & 10 & من · . . . \\
\hline 18.0 & Y I & 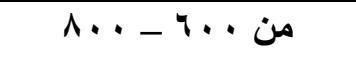 \\
\hline YI.V & rq & 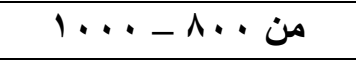 \\
\hline 14.4 & 17 & من +. \\
\hline$r \cdot . \Lambda$ & ro & 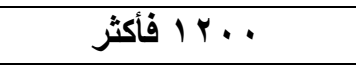 \\
\hline $1 \cdots$ & Ir. & المجموع \\
\hline
\end{tabular}




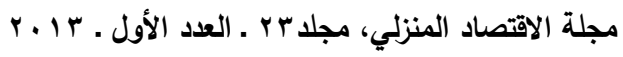

تابع جدول ( اr) وصف عينة الدراسة

\begin{tabular}{|c|c|c|}
\hline الأنسبة \% & العدد & عدد أفراد الأسرة \\
\hline $1 \varepsilon . Y$ & $1 V$ & ثُّلاث \\
\hline r & YA & أربع \\
\hline YV.0 & 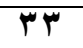 & خمس \\
\hline Ir.r & 17 & ست \\
\hline $9 . Y$ & 11 & سبع \\
\hline $1 Y .0$ & 10 & ثماتية فَأكثر \\
\hline $1 \ldots$ & IY. & المجموع \\
\hline النسبة 0 & العدد & مكان السكن \\
\hline$V$ & $\Lambda \varepsilon$ & سكن مستقل \\
\hline 19.9 & $r r$ & مع عائلة الزوج \\
\hline 7.8 & $\Lambda$ & مع عائلة الزوجة \\
\hline$\varepsilon .1$ & 0 & أخرى تذكر \\
\hline $1 \ldots$ & IY. & المجموع \\
\hline النسبة \% & العدد & مدة الزواج \\
\hline $1 \wedge . r$ & Yr & من "r - \\
\hline r.r. & $\varepsilon$. & من V - 1. \\
\hline$\varepsilon \Lambda . \mu$ & $0 \wedge$ & 1ا فأكثُر \\
\hline $1 \cdots$ & IY. & المجموع \\
\hline
\end{tabular}

تابع جدول ( اr) وصف عينة الدراسة

\begin{tabular}{|c|c|c|c|}
\hline النسبة \% & العدد & \multicolumn{2}{|c|}{ الاخل } \\
\hline$Y .0$ & $r$ & \multirow{5}{*}{ وظائف دنيا } & مزارع \\
\hline 7.8 & $\Lambda$ & & فراش \\
\hline$\varepsilon . Y$ & 0 & & فكهانى \\
\hline$r . r$ & $\varepsilon$ & & بقال \\
\hline 0 & 7 & & ميكاتيكى \\
\hline IT.r & 17 & \multirow{4}{*}{ متوسطة } & أعمال إدارية \\
\hline $1 \cdot .1$ & $1 \%$ & & فُخى خراطة \\
\hline $7 . V$ & $\Lambda$ & & سكرتيز \\
\hline $9 . Y$ & 11 & & موظف حكومة \\
\hline 11.7 & $1 \varepsilon$ & \multirow{4}{*}{ وظائف عليا } & محامى \\
\hline $1 \varepsilon . Y$ & $1 V$ & & محاسب \\
\hline 0 & 7 & & طبيب \\
\hline$V .0$ & 9 & & مـندس \\
\hline $\mathbf{0} / \ldots$ & IY. & & المجموع \\
\hline النسبة \% & العدد & \multicolumn{2}{|c|}{ عمل الزوجة } \\
\hline$\varepsilon \cdot . \Lambda$ & $\varepsilon 9$ & \multicolumn{2}{|c|}{ تعمل } \\
\hline
\end{tabular}




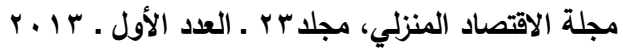

\begin{tabular}{|c|c|c|c|}
\hline 09.4 & VI & \multicolumn{2}{|r|}{ لا تعمل } \\
\hline $1 \cdots$ & TY. & \multicolumn{2}{|r|}{ المجموع } \\
\hline النسبة \% & العدد & \multicolumn{2}{|r|}{ وظيفة } \\
\hline$\Lambda . Y$ & $\xi$ & \multirow{2}{*}{ ونيائف } & قُلاحة \\
\hline $1 \cdot . Y$ & 0 & & فرزاشَّة \\
\hline$Y \cdot . \varepsilon$ & 1. & \multirow{2}{*}{ متوسطة } & عاملة على ماكينة \\
\hline$r \leqslant .0$ & TY & & سكرتيرة \\
\hline $1 \cdot . r$ & 0 & \multirow{3}{*}{ عليا } & محامية \\
\hline $1 \Lambda . r$ & 9 & & مدرسة \\
\hline$\Lambda . Y$ & $\varepsilon$ & & دكتورة \\
\hline$\% 1 \ldots$ & $\varepsilon 9$ & & المجموع \\
\hline
\end{tabular}

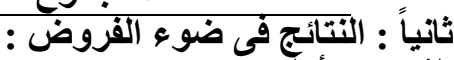

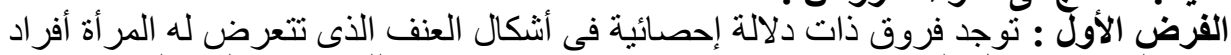

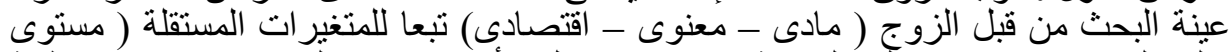

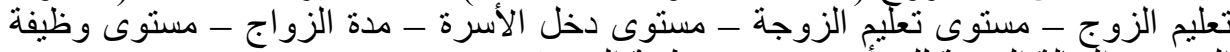

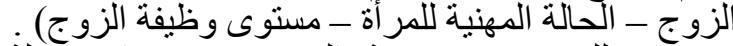

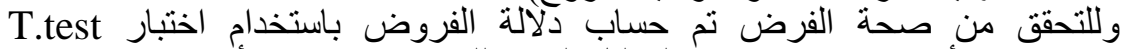

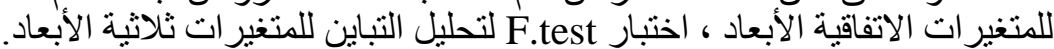

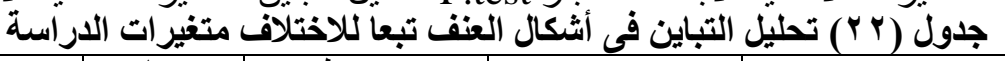

\begin{tabular}{|c|c|c|c|c|c|}
\hline الدلالة & قيمة (ف) & الحرية & المربعات & المربعاتع & مصدر التباين \\
\hline \multirow{4}{*}{ ' } & & & & & تعليم الزوج : \\
\hline & \multirow{3}{*}{ rT.TVq } & & & & العنف المادى \\
\hline & & T & $T V E T . Y T V$ & $V \leqslant \wedge 7 . \leqslant 0 r$ & بين المجمو عات \\
\hline & & $11 \mathrm{~V}$ & 101.1. & $1 \wedge \leqslant 90 . \leqslant 1 \%$ & المجمو عات داخل \\
\hline & & 119 & & TOQNI.ATV & المجموع \\
\hline \multirow{3}{*}{ ' } & \multirow{3}{*}{$\leq 0.01 \mathrm{~V}$} & & & & العنف المادى \\
\hline & & T & $N 1 \leqslant 7.194$ & ITะQT.TAV & بين المجمو عات \\
\hline & & $11 \mathrm{~V}$ & 111.177 & $r / 197 . \varepsilon 1 r$ & المجمو عات \\
\hline \multirow{6}{*}{ ' } & & 119 & & 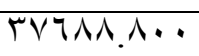 & المجموع \\
\hline & \multirow{3}{*}{$\left.\leq v_{.}\right) \ldots$} & & & & العنف المادى \\
\hline & & T & $|\leq \lambda \mu . V|$ & Y97V.r $\leqslant Y$ & بين المجمو عات \\
\hline & & $11 \mathrm{~V}$ & 4.0 .1 & rฯ10.01r & المجمو عات \\
\hline & & 119 & & 770 T.9Y0 & المجموع \\
\hline & & & & & تعليم الزوججه : \\
\hline \multirow{2}{*}{ ' } & \multirow{2}{*}{ YO.9YA } & T & TEV0.911 & ह901.9VV & لين المنفمي المادى عات \\
\hline & & $11 \mathrm{~V}$ & $90 . \leqslant 97$ & $11 V T .10$ & المجمو عات \\
\hline
\end{tabular}




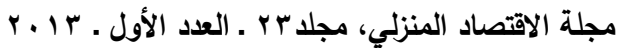

\begin{tabular}{|c|c|c|c|c|c|}
\hline & & 119 & & $171 T 5.999$ & المجموع \\
\hline \multirow{4}{*}{ 'دانَ' } & \multirow{3}{*}{$r V . \leqslant \leqslant 1$} & & & & العنف المآدى \\
\hline & & r & TVरा.771 & $|T \varepsilon \varepsilon| . T \mid$ & بين المجمو عات \\
\hline & & $11 \mathrm{r}$ & 1V9.0\% & $\left.Y_{1}\right) \leq \leqslant 0 \leqslant 7$ & المجمو عات \\
\hline & & 119 & & 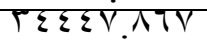 & المجموع \\
\hline \multirow{5}{*}{ 'دان } & \multirow{3}{*}{$\varepsilon 0 . T V T$} & & & & العنف المكادى \\
\hline & & t & TTM.TET & T707. EAE & بين المجمو عات \\
\hline & & $11 \mathrm{~V}$ & $49 . \cdot 11$ & $r \varepsilon \cdot r_{.0 .1}$ & المجمو عاتات \\
\hline & & 119 & & 9.01 .991 & المجموع \\
\hline & & & & & دخل الاسرة \\
\hline \multirow{3}{*}{ 'دانْ } & \multirow{3}{*}{$\varepsilon .071$} & & & & العنف المادى \\
\hline & & $T$ & 17.0 .090 & $\nabla T 1.19$ & بين المجمو عات \\
\hline & & $11 \mathrm{~V}$ & $\Lambda \Lambda . \wedge \vee \Lambda$ & $1 . r 9 \Lambda .7 V \mathrm{~V}$ & المجموعات \\
\hline & & 119 & & $T V 7.9 .17 V$ & المجموع \\
\hline \multirow{3}{*}{ 'دانَ' } & \multirow{3}{*}{$00 . \wedge r}$. & T & $79 . V>79$ & TIAIE VVT & لين العنف المحو عادي \\
\hline & & & & & ... \\
\hline & & $11 \mathrm{~V}$ & $1 T r . V \varepsilon \varepsilon$ & $1 \leqslant \leqslant V \Lambda .09$ & المجمو عات \\
\hline \multirow{4}{*}{ دانَ' } & \multirow{4}{*}{$9 . M T r$} & 111 & & 1011.87 & المجموع ع \\
\hline & & $T$ & $\varepsilon .1 .011$ & $1 \cdot 1 \cdot V^{\top}$ & بين المجمو المادى \\
\hline & & $11 \mathrm{~V}$ & $\sum r .99 V$ & $0 . T \cdot .7 Y \leq$ & المجمو عاتل \\
\hline & & 119 & & $0110 . \mathrm{V} \cdot$ & المجموع \\
\hline 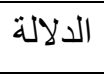 & قيمة (ف) & الحرجات & المربعات & المربعوت & مصدر التباين \\
\hline \multirow{4}{*}{ 'دانز } & \multirow{3}{*}{$\varepsilon V .100$} & & & & مدة المزواج : المادى \\
\hline & & $T$ & $\varepsilon / 9 \varepsilon .0 .1$ & NT19.. & بين المجمو عات \\
\hline & & $11 \mathrm{~V}$ & NV. 70. & $1 . Y 00.1 \cdot 1$ & المجمو عات \\
\hline & & 119 & & |АTEะ.1TO & المجموع \\
\hline \multirow{3}{*}{ دانَ' } & \multirow{3}{*}{ Ir.Va. } & & & & العنف المادى \\
\hline & & 1 & 1010.1 .1 & $0.0 \cdot .111$ & بين المجمو عات \\
\hline & & $11 \mathrm{~V}$ & $19 V . \leqslant \leq 1$ & $r \mu 1.1 . r v q$ & المجمو عات \\
\hline \multirow{5}{*}{ دانَ' } & \multirow{4}{*}{$11 . \leqslant \leq \varepsilon$} & 119 & & 11101.991 & المجموع \\
\hline & & $T$ & 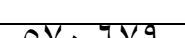 & $1<1501$ & العنف المادى. \\
\hline & & $\frac{1}{1}$ & 每. & 16.10 & بين المجمو عات \\
\hline & & $11 \mathrm{~V}$ & $\leq 9.171$ & $0 \wedge r \leqslant .07 V$ & المجمو عات \\
\hline & & 119 & & $79 \times 0.910$ & المجموع \\
\hline
\end{tabular}




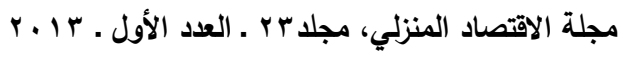

تابع جدول (Y Y)تحليل التباين فى أشكال العنف تبعا للاختلاف متغيرات الدراسة

\begin{tabular}{|c|c|c|c|c|c|}
\hline الدلالة & قيمة (ف) & الحربية & المربعات & المربعوع & مصدر التباين \\
\hline \multirow{5}{*}{ 'دالْ } & & & & & وظيفة الزوج: \\
\hline & \multirow{3}{*}{$\varepsilon \varepsilon . \wedge r q$} & & & & العنف المادى \\
\hline & & T & $r \leqslant r Y .011$ & $T \Lambda \leqslant 0 . \cdot T Y$ & بين المجمو عات \\
\hline & & $11 \mathrm{~V}$ & VI.TYq & $\wedge 94 \cdot . \leqslant \leq 0$ & داخل المجموعات \\
\hline & & 119 & & 10VV0.57V & المجموع \\
\hline \multirow{4}{*}{ دال } & \multirow{4}{*}{$0 V .017$} & & & & العنف المادى \\
\hline & & $r$ & 7r9Y. & TYVY & بين المجمو عات \\
\hline & & $11 \mathrm{~V}$ & $11 \cdot . \leqslant 10$ & IYqYT.VA. & داخل المجمو عات \\
\hline & & 119 & & r0701.V.. & المجموع \\
\hline \multirow{4}{*}{ 'داز } & \multirow{4}{*}{$r r_{.} \cdot \Lambda \Lambda$} & & & & العنف المادى \\
\hline & & $r$ & $\Lambda V \cdot . Y I V$ & $I V \varepsilon \cdot . \Sigma \Gamma \leqslant$ & بين المجمو عات \\
\hline & & $11 \mathrm{~V}$ & rq. rqV & $\varepsilon 7.9 . \varepsilon r \mu$ & داخل المجمو عات \\
\hline & & 119 & & 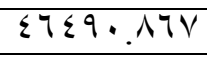 & المجموع \\
\hline \multirow[t]{2}{*}{ الدلالة } & \multirow[t]{2}{*}{ قيمة (ف) } & الحرية & متوسط المربعات & المربعوع & مصدر التباين \\
\hline & & & & & وظيفة الزوجة : \\
\hline \multirow{3}{*}{ دان } & \multirow{3}{*}{$r \wedge . \wedge \leqslant 1$} & & & & العنف المادى \\
\hline & & r & I.TY.IA乏 & 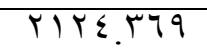 & بين المجمو عات \\
\hline & & $\varepsilon 7$ & rq.Arq & $1795.1 Y 1$ & داخل المجمو عات \\
\hline \multirow{5}{*}{ دال } & & $\varepsilon \wedge$ & & 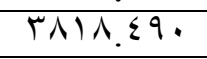 & المجموع \\
\hline & \multirow{3}{*}{$\leq 0.9 \leq r$} & & & & العنف المادى \\
\hline & & T & $T r \leqslant 0 .\{7)$ & $\leqslant 79 . .9 Y T$ & بين المجمو عات \\
\hline & & $\sum 7$ & 01.04 & $T r \leq \Lambda . \leqslant T \leqslant$ & داخل المجمو عات \\
\hline & & $\varepsilon \wedge$ & & $V \cdot r q . r \leq V$ & المجموع \\
\hline \multirow{4}{*}{ 'ُ } & \multirow{4}{*}{ 10.rTr } & & & & العنف المادى \\
\hline & & $r$ & $\varepsilon .7 .40$ & AIY.V.. & بين المجمو عات \\
\hline & & $\sum 7$ & TY.TYT & IYY $\{.7 \leqslant 7$ & داخل المجمو عات \\
\hline & & $\leqslant \wedge$ & & $r \cdot r V . r \leq V$ & المجموع \\
\hline \multicolumn{6}{|c|}{ 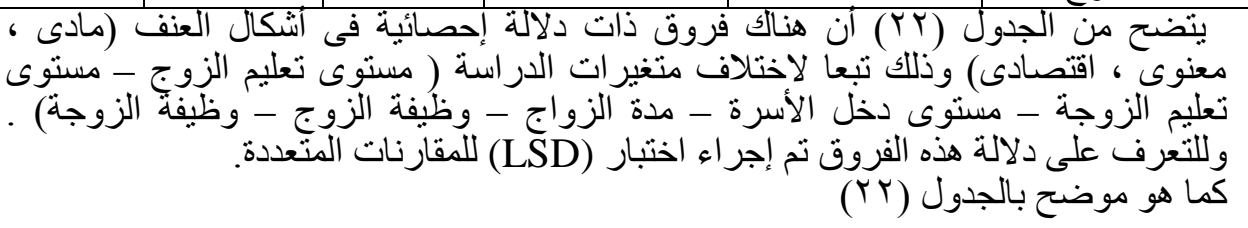 } \\
\hline
\end{tabular}




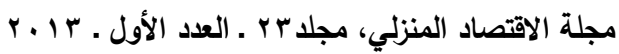

جدول (Y Y د دلالة الفروق فى متوسطات أشكال العنف تبعا لاختلاف متغيرات الدراسة

\begin{tabular}{|c|c|c|c|}
\hline 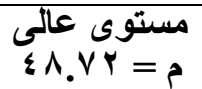 & 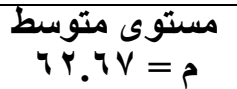 & 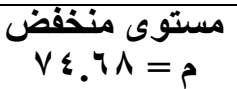 & عنف مادى \\
\hline & & & تعليم الزوج : \\
\hline & - & - & مستوى منخفضض \\
\hline & - & $* * \mid Y .1$ & مستوى متوسط \\
\hline & $* * 11.9 \leq$ & $* *$ Y0.97 & مستوى عالى \\
\hline \multirow[t]{4}{*}{ 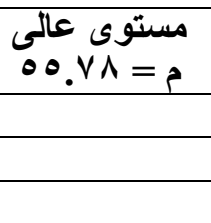 } & 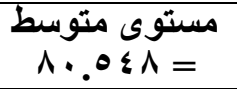 & 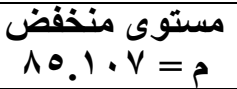 & عنف معنوى \\
\hline & & - & مستوى منخفض \\
\hline & - & $* \leqslant .07$ & مستوى متوسط \\
\hline & $* * Y \leq . V V$ & $* * r q . \mu r$ & مستوى عالى \\
\hline \multirow[t]{4}{*}{ 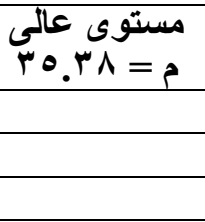 } & 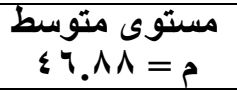 & 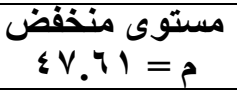 & عنف اقتصادى \\
\hline & & - & مستوى منخفض \\
\hline & - &.$V T$ & مستوى متوسط \\
\hline & 11.0 & **IY.YY & مستوى عالى \\
\hline \multirow[t]{5}{*}{ 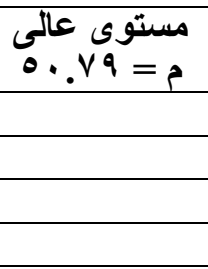 } & 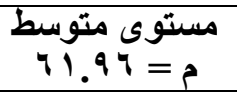 & مستوى منخفض = ا. 7. & عنف مادى \\
\hline & & & تعليم الزوجة : \\
\hline & - & - & مستوى منخفض \\
\hline & - & $* \leqslant .00$ & مستوى متوسط \\
\hline & $* * 11.17$ & $* 10 . V Y$ & مستوى عالى \\
\hline \multirow[t]{4}{*}{ 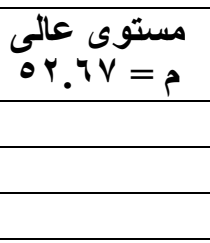 } & 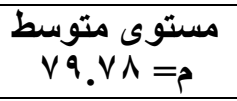 & 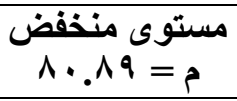 & عنف معنوى \\
\hline & & - & مستوى منخفض \\
\hline & - & 1.1. & مستوى منوسط \\
\hline & **YV.II & **Y^.r & مستوى عالى \\
\hline \multirow[t]{4}{*}{ م = مستوى عالّى } & 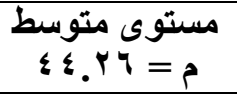 & 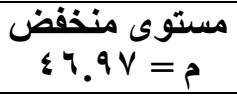 & عنف اقتصادى \\
\hline & & - & مستوى منخفض \\
\hline & - & $* Y . V I$ & مستوى متوسط \\
\hline & $* * \wedge .09$ & $* * 11 . \mu$ & مستوى عالى \\
\hline \multirow[t]{5}{*}{ 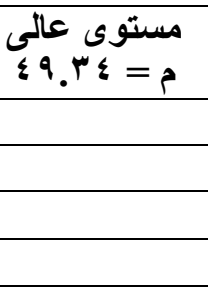 } & 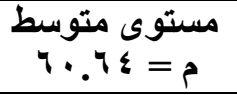 & 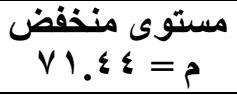 & عنف مادى \\
\hline & & & دخل الأسرة : \\
\hline & - & - & مستوى منخفض \\
\hline & - & $* * 1 \cdot . \wedge 9$ & مستوى متوسط \\
\hline & $* * \| . \mu$ & $* * Y Y .1 \wedge$ & مستوى عالى \\
\hline
\end{tabular}




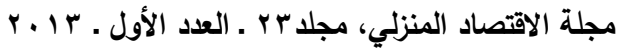

\begin{tabular}{|c|c|c|c|}
\hline 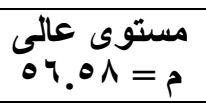 & 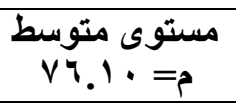 & 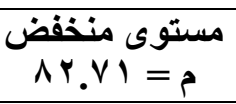 & عنف معنوى \\
\hline & & - & مستوى منخفض \\
\hline & - & $* * 7.71$ & مستوى متوسط \\
\hline & $* * 19$. Yo & $* * Y 0 . \wedge \vee$ & مستوى عالى \\
\hline \multirow[t]{4}{*}{ 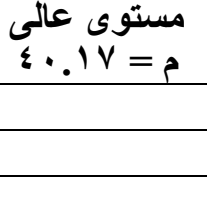 } & 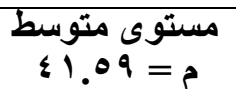 & مستوى منخفض & عنف اقتصادى \\
\hline & & - & مستوى منخفض \\
\hline & - & *ย.r & مستوى متو سط \\
\hline & $1 . \leqslant Y$ & $* * 0 . V T$ & مستوى عالى \\
\hline \multirow[t]{4}{*}{ مد مدة طويلة } & 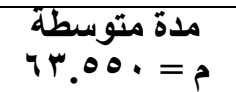 & 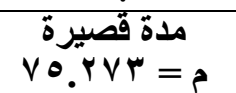 & عنف مادى \\
\hline & & & مدة الزواج : \\
\hline & - & - & مدة قصيرة \\
\hline & - & $* * ! 1 . V Y$ & مدة متوسطة \\
\hline- & $* *)$ r. $\leqslant 9$ & ** Y $\{. Y Y$ & مدة طويلة \\
\hline \multirow[t]{4}{*}{ 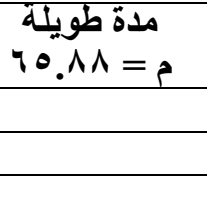 } & 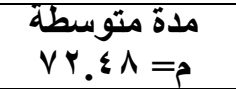 & 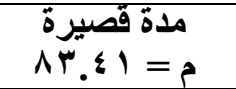 & عنف معنوى \\
\hline & & - & مدة قصيرة \\
\hline & - & $* * 1 \cdot .94$ & مدة متوسطة \\
\hline & $* 7.09$ & $* * I V .0 r$ & مدة طويلة \\
\hline \multirow[t]{4}{*}{ 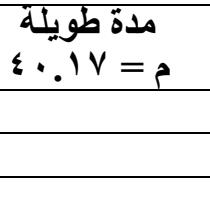 } & مدة متوسطة & 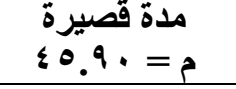 & عنف اقتصادى \\
\hline & & - & مدة قصيرة \\
\hline & - & $* 0 . \leqslant 9$ & مدة منو سطة \\
\hline & 1.10 & **V.YO & مدة طويلة \\
\hline \multirow[t]{4}{*}{ 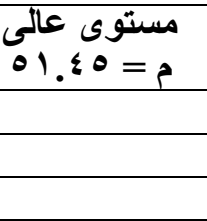 } & 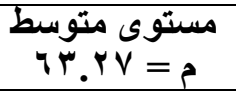 & مستوى منخفض & عنف مادى \\
\hline & & & وظيفة الزوج : \\
\hline & - & - & مستوى منخفض \\
\hline & - & $* * \|$ I.VT & مستوى متوسط \\
\hline- & $* * \backslash$ Y $\leqslant q$ & $* * Y \leq . Y Y$ & مستوى عالى \\
\hline \multirow[t]{4}{*}{ 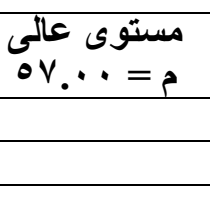 } & 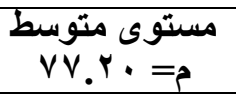 & 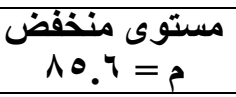 & عنف معنوى \\
\hline & & - & مستوى منخفض \\
\hline & - & $* * \wedge . \Sigma \varepsilon$ & مستوى متوسط \\
\hline & $* Y \cdot . r \cdot$ & $* * ץ \wedge .70$ & مستوى عالى \\
\hline \multirow[t]{3}{*}{ 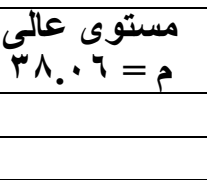 } & 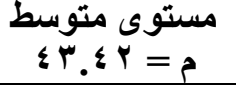 & 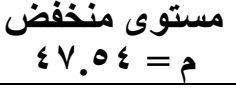 & عنف اقتصادى \\
\hline & & - & مستوى منخفض \\
\hline & - & **६. I T & مستوى متو سط \\
\hline
\end{tabular}




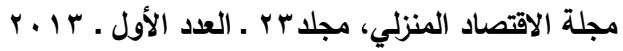

\begin{tabular}{|c|c|c|c|}
\hline & $* * 0$. ro & $* * q . \leqslant V$ & مستوى عالى \\
\hline \multirow[t]{4}{*}{ 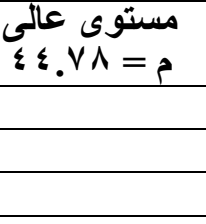 } & 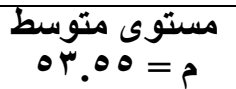 & 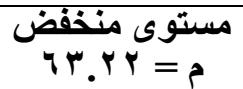 & عنف مادى \\
\hline & & & وظيفة الزوجة : \\
\hline & - & - & مستوى منخفض \\
\hline & - & $* * 9.71$ & مستوى متوسط \\
\hline- & $* * \wedge . \vee \vee$ & $* * \mid \wedge . \Sigma \varepsilon$ & مستوى عالى \\
\hline \multirow[t]{4}{*}{ 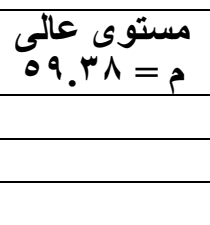 } & 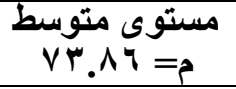 & 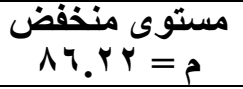 & عنف معنوى \\
\hline & & - & مستوى منخفض \\
\hline & - & **IY.Y & مستوى متو سط \\
\hline & $* *) \leqslant . \leqslant V$ & $* * Y\urcorner . \wedge \Gamma$ & مستوى عالى \\
\hline \multirow[t]{4}{*}{ مستوى عاب. عالى } & 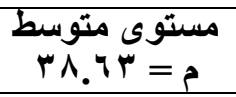 & 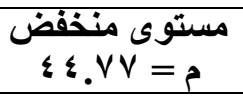 & عنف اقتصادى \\
\hline & & - & مستوى منخفض \\
\hline & - & $* * 7.1 \leq$ & مستوى متوسط \\
\hline & $* * 0, r$. & $* * \|$ П $\leqslant \varepsilon$ & مستوى عالى \\
\hline
\end{tabular}

يتضح من الجدول (Tr (T) وجود فروق ذات دلالة إحصائية فى جميع أشكال العنف الممارس

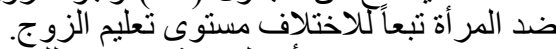

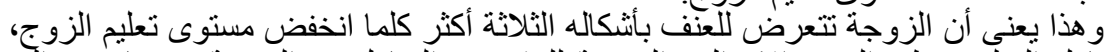

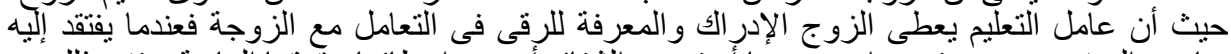

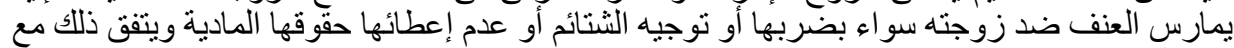

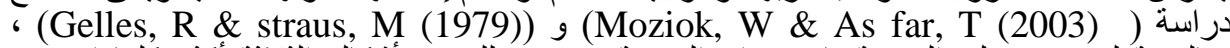
وبالنسبة لمسنوى تعليم الزورجة فاتضح ان الزوجة تنعرض للعنف بأنثكاله الثلاثة أكثر كلما انخفض

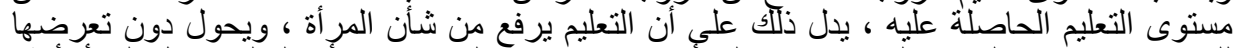

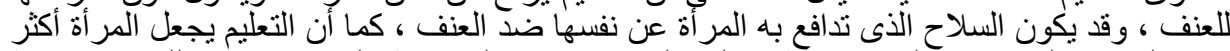

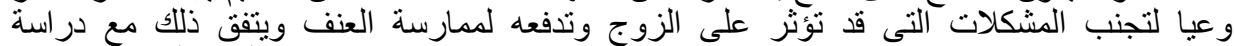
(Richard gelles (1972)) ، (Moziok, W \& As far, T (2003) )

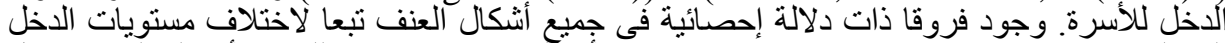

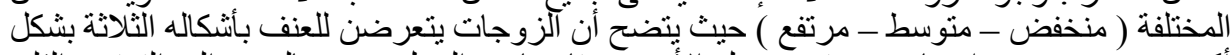

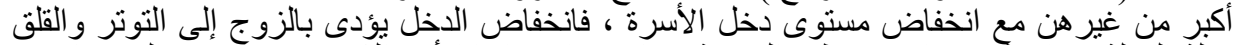

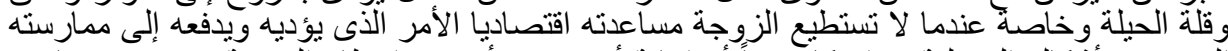

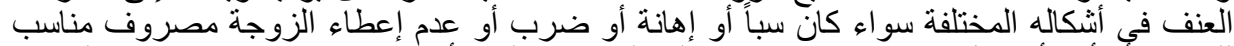

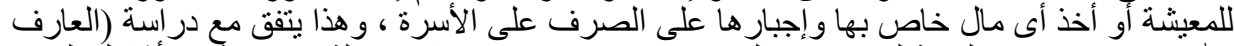

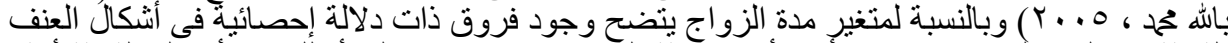

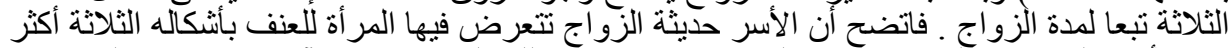

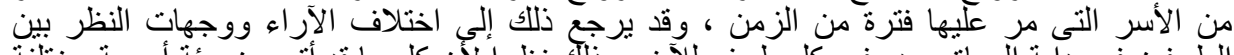

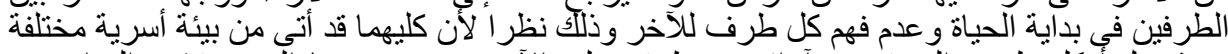

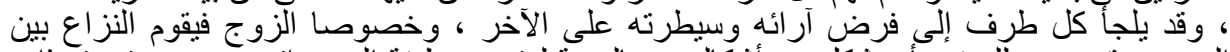

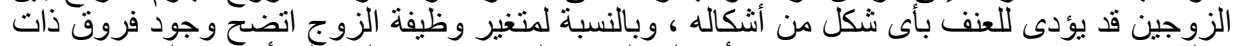

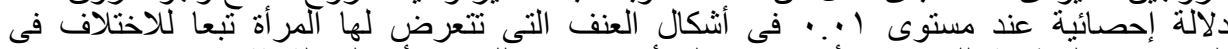

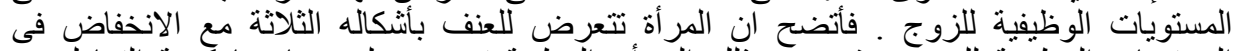

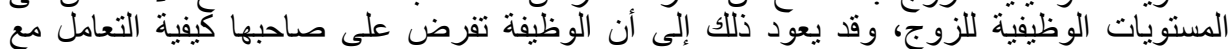

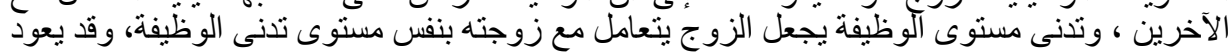




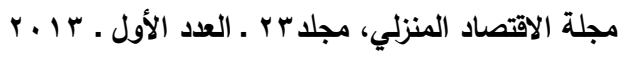

ذلك إلى نوعية الأشخاص الذين يتعامل معهم الزوج وأساليب التعامل ، ويتفق ذلك مع دراسة

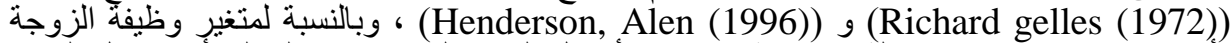

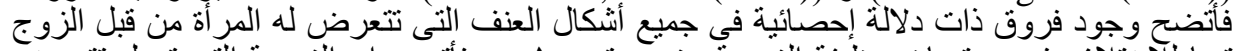

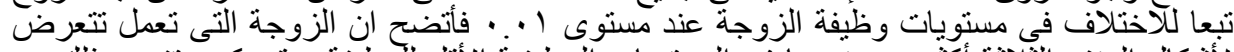

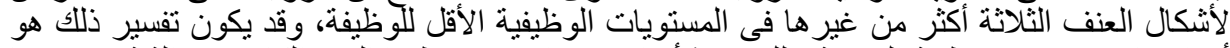

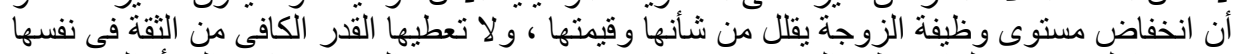

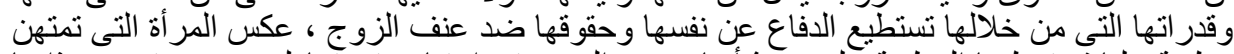

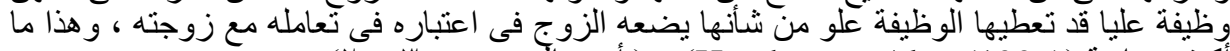

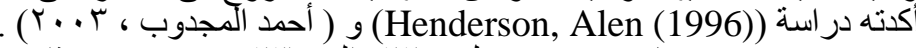

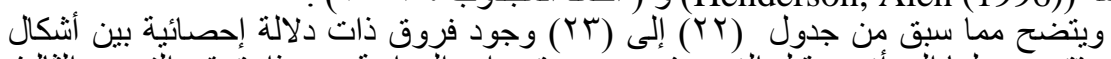

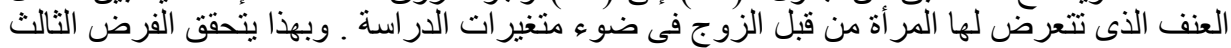

توجد فروق ذات دلالة إحصائية فى أسباب العنف الذى تتعرض لـ له المر أة أفر اد عينة البحث

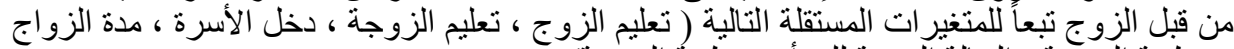

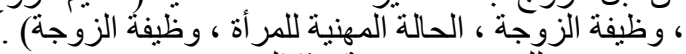

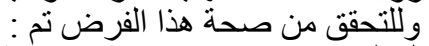

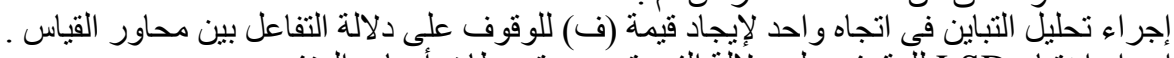

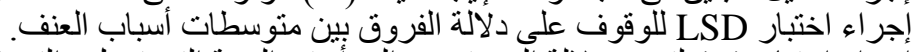

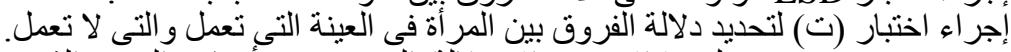

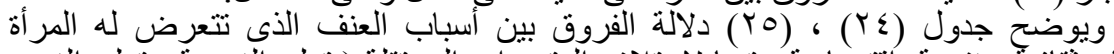

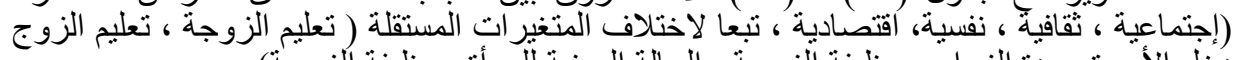

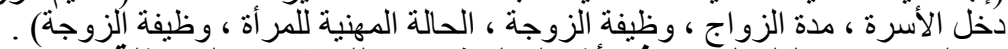

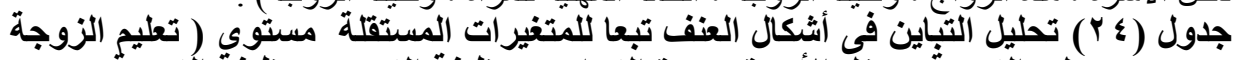

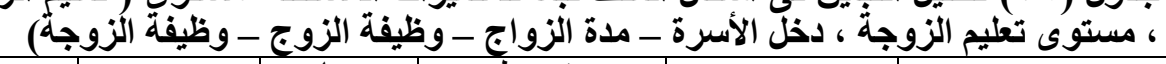

\begin{tabular}{|c|c|c|c|c|c|}
\hline الدلالة الد & قيمة (ف) & الحربية & المربعات & المربعات & مصدر التباين \\
\hline \multirow{5}{*}{ 'ُ } & & & & & تعليم الزوج: \\
\hline & \multirow{4}{*}{$\sum \vee . \wedge \wedge 1$} & & & & أسباب اجتماعية \\
\hline & & $r$ & $1 V .7 .000$ & $r \leqslant 1 r .111$ & بين المجمو عات \\
\hline & & $11 \mathrm{~V}$ & To.TrY & $\varepsilon 1 \vee \cdot . \wedge q$ & داخل المجمو عات \\
\hline & & 119 & & VOAT.Y. & المجموع \\
\hline \multirow{4}{*}{ 'ُ } & \multirow{4}{*}{$r \cdot .9 r}$. & & & & أسباب ثقافية \\
\hline & & tr & $\Lambda \vee \cdot . \wedge \wedge$ & IVミ).7TV & بين المجمو عات \\
\hline & & $\pi \mathrm{V}$ & YA.17£ & rY90.17r & داخل المجمو عات \\
\hline & & 119 & & $0 . \mu 7.1 \ldots$ & المجموع \\
\hline \multirow{4}{*}{ 'الز } & \multirow{3}{*}{ r..人11 } & & & & أسباب أتتصنادية \\
\hline & & $r$ & $174 . .1$ & r r & بين المجمو عات \\
\hline & & $11 \mathrm{~V}$ & 0.94 & $090 . \wedge Y \wedge$ & داخل المجمو عات \\
\hline & & 119 & & $919 . \lambda \mu 1$ & المجموع \\
\hline \multirow{4}{*}{ 'ُ } & \multirow{3}{*}{ ov.V19 } & & & & أسباب نفسية \\
\hline & & $r$ & $0 \cdot .711$ & W.IYY & بين المجمو عات \\
\hline & & $11 \mathrm{~V}$ & $\wedge .7 V \mu$ & $1 \cdot 1 \leqslant . V V \cdot$ & داخل المجمو عات \\
\hline & & 119 & & & المجموع \\
\hline
\end{tabular}




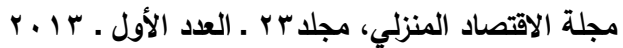

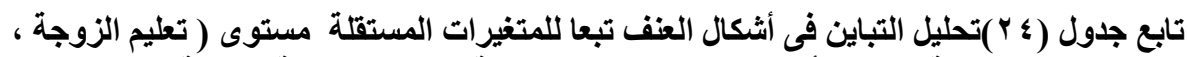

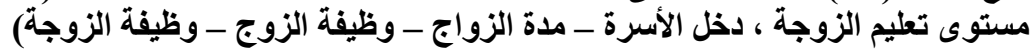

\begin{tabular}{|c|c|c|c|c|c|}
\hline الدلالة الد & قيمة (ف) & الحرية & متوسط المربعات & مجموع المربعات & مصدر التباين \\
\hline & & & & & تعليم الزوجة: \\
\hline \multirow{4}{*}{ إ·.• } & \multirow{3}{*}{$09.70 \mathrm{~V}$} & & & & الأسباب اجتماعية \\
\hline & & $r$ & $17 \varepsilon 1.491$ & rYAY.V9T & بين المجموعات \\
\hline & & $11 \mathrm{~V}$ & $Y V .010$ & rYIQ.1Yq & داخل المجمو عات \\
\hline & & 119 & & 70.1 .910 & المجموع \\
\hline \multirow{4}{*}{ י •.•• دال } & \multirow{3}{*}{$r . q . r$} & & & & الأسباب ثقافية \\
\hline & & $r$ & $7 \vee \wedge .911$ & IrOV.ArT & بين المجموعات \\
\hline & & $11 \mathrm{~V}$ & r. & $r \varepsilon \backslash \leqslant .1 \wedge q$ & داخل المجمو عات \\
\hline & & 119 & & TVVI.9Yo & المجموع \\
\hline \multirow{4}{*}{ ا •.• } & \multirow{3}{*}{ Y..01. } & & & & الأسباب اقتصـادية \\
\hline & & r & 104.110 & r.T.YYq & بين المجمو عات \\
\hline & & $11 \mathrm{~V}$ & OrVVT & TVO.VTY & داخل المجمو عات \\
\hline & & 119 & & 911.991 & المجموع \\
\hline \multirow{5}{*}{ י •.•• دال } & \multirow{3}{*}{$r T . \cdot r T$} & & & & الأسباب نفسية \\
\hline & & $r$ & Yr4.711 & EVT.TTY & بين المجموعات \\
\hline & & $11 \mathrm{~V}$ & $1 . r \vee q$ & IY.Y.7.0 & داخل المجمو عات \\
\hline & & 119 & & $17 V 0.97 V$ & المجموع \\
\hline & & & & & لخل الأسرة : \\
\hline \multirow{4}{*}{ י •.•• دال } & \multirow{3}{*}{$r 9.9 \cdot 1$} & & & & أسباب اجتماعية \\
\hline & & $r$ & IIrA.rVq & YY07.007 & بين المجمو عات \\
\hline & & $11 \mathrm{~V}$ & MV.VYO & $\varepsilon \leqslant 1 \Gamma . \wedge \cdot \wedge$ & داخل المجموعات \\
\hline & & 119 & & TIV. TTV & المجموع \\
\hline \multirow{4}{*}{ י •.•• } & \multirow{3}{*}{ סדז. } & & & & أسباب ثقافية \\
\hline & & $r$ & $0 \vee 9.7 \leq 9$ & 1109.199 & بين المجموعات \\
\hline & & $11 \mathrm{~V}$ & IV.rVT & r.Tr.7TA & داخل المجمو عات \\
\hline & & 119 & & $r .91 .97 \mathrm{~V}$ & المجموع \\
\hline \multirow{4}{*}{ י •.• } & \multirow{3}{*}{$\leqslant r . \wedge 97$} & & & & أسباب اقتصادية \\
\hline & & $r$ & $1 \leqslant \Lambda .+7 V$ & rq7.Irr & بين المجمو عات \\
\hline & & $11 \mathrm{~V}$ & r.rVT & r9ะ.709 & داخل المجمو عات \\
\hline & & 119 & & $79 . .194$ & المجموع \\
\hline \multirow{4}{*}{ ا •.•• دال } & \multirow{4}{*}{17.71.} & & & & أسباب نفسية \\
\hline & & $r$ & TII.TYA & EYY.TOV & بين المجموعات \\
\hline & & $11 \mathrm{~V}$ & r.rVT & r9ะ.709 & داخل المجمو عات \\
\hline & & 119 & & 19. Y.rTV & المجموع \\
\hline
\end{tabular}




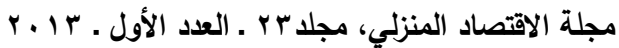

\begin{tabular}{|c|c|c|c|c|c|}
\hline & & & & & وظيفة الزوج: \\
\hline \multirow{4}{*}{ ו... دال } & \multirow{3}{*}{$9 . \leqslant V}$. & & & & أسباب اجتماعية \\
\hline & & $r$ & $\varepsilon 0 r_{V}$ VI & $q \cdot v \leqslant \leqslant 1$ & بين المجمو عات \\
\hline & & 118 & $\varepsilon V . q 1 T$ & $07.0 . \wedge \varepsilon \varepsilon$ & داخل المجمو عات \\
\hline & & 119 & & TOMTYMO & المجموع \\
\hline \multirow{4}{*}{ ا •. • دال } & \multirow{3}{*}{ rq. $\leqslant$. } & & & & أسباب ثقافية \\
\hline & & $r$ & OYV.Y.r & $1.0 \leqslant . \leqslant .7$ & بين المجمو عات \\
\hline & & $11 \mathrm{~V}$ & IT.TVE & $107 \varepsilon .17$. & داخل المجمو عات \\
\hline & & 119 & & Y719.17V & المجموع \\
\hline \multirow{4}{*}{ ו •. • دال } & \multirow{3}{*}{$1 \leqslant . \varepsilon Y r$} & & & & أسباب اقتصـادية \\
\hline & & $r$ & $v \cdot \vee 9 \wedge$ & $1 \leqslant 1.090$ & بين المجمو عات \\
\hline & & $11 \mathrm{~V}$ & $\varepsilon .9 .9$ & $O V \varepsilon . Y V Y$ & داخل المجمو عات \\
\hline & & 119 & & $810.97 \mathrm{~V}$ & المجموع \\
\hline \multirow{5}{*}{ ו •. • دال } & \multirow{3}{*}{ IV.YTA } & & & & أسباب نفسية \\
\hline & & $r$ & $1 \wedge 9 . \wedge 7 \wedge$ & rVq.VTq & بين المجمو عات \\
\hline & & 118 & 1.990 & IYAT.EVY & داخل المجمو عات \\
\hline & & 119 & & 1777.4 .1 & المجموع \\
\hline & & & & & وظيفة الزوجة : \\
\hline \multirow{4}{*}{ ו •.• دال } & \multirow{3}{*}{$1 . \wedge \vee \wedge$} & & & & أسباب اجتماعية \\
\hline & & $r$ & $01 \cdot .9 \vee \leqslant$ & $1 . Y 1.9 \leq V$ & بين المجمو عات \\
\hline & & $\varepsilon 7$ & $\leqslant 7.9 \vee 0$ & YIT.AYA & داخل المجمو عات \\
\hline & & $\leqslant \curlywedge$ & & rIAY.VVT & المجموع \\
\hline \multirow{4}{*}{ '•. • دال } & \multirow{3}{*}{$1 \varepsilon .109$} & & & & أسباب ثقافية \\
\hline & & $r$ & $117.99 \mathrm{~V}$ & $\varepsilon r .990$ & بين المجمو عات \\
\hline & & $\varepsilon 7$ & $10 . M Y 7$ & $V \cdot \leqslant 9.9 \wedge 0$ & داخل المجمو عات \\
\hline & & $\varepsilon \wedge$ & & $11 r \wedge .91$. & المجموع \\
\hline \multirow{4}{*}{ 1 •. • دال } & \multirow{3}{*}{11. YVT } & & & & أسباب اقتصادية \\
\hline & & $r$ & $\varepsilon \cdot \Gamma \leqslant \Lambda$ & 1.790 & بين المجمو عات \\
\hline & & $\sum 7$ & r.ova & $17 \varepsilon .70 \%$ & داخل المجمو عات \\
\hline & & $\sum \Lambda$ & & $r \leqslant 0 . r \leqslant V$ & المجموع \\
\hline \multirow{5}{*}{ '•. • دال } & \multirow{3}{*}{$V .7 V \varepsilon$} & & & & أسباب نفسية \\
\hline & & $r$ & 1.0 .8 .0 & YII. & بين المجمو عات \\
\hline & & $\Sigma 7$ & Ir.VVO & THT.7OY & داخل المجموعات \\
\hline & & $\leqslant \Lambda$ & & $\wedge \leqslant 0.7 r$ & المجموع \\
\hline & & & & & مدة الزواج : \\
\hline \multirow{3}{*}{ I. . • دال } & \multirow{3}{*}{1.940} & & & & أسباب اجتماعية \\
\hline & & $r$ & Oro.sT. & $1 \cdot V \cdot . \wedge 7$. & بين المجمو عات \\
\hline & & $11 \mathrm{~V}$ & $\varepsilon \wedge .97 \varepsilon$ & OVYA.VTY & داخل المجمو عات \\
\hline
\end{tabular}




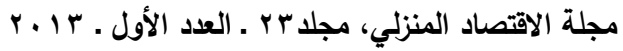

\begin{tabular}{|c|c|c|c|c|c|}
\hline & & 119 & & $7 V 99.09 Y$ & المجموع \\
\hline \multirow{4}{*}{ ו •..• دال } & \multirow{4}{*}{$01 . v \ldots$} & & & & أسباب ثقافية \\
\hline & & $r$ & $V \leqslant 0.1 \leqslant \Lambda$ & $1 \leqslant 9 . .190$ & بين المجمو عات \\
\hline & & $11 \mathrm{~V}$ & $1 \varepsilon . \varepsilon 1 \pi$ & $1717.49 \mathrm{~V}$ & داخل المجمو عات \\
\hline & & 119 & & rIV7.09r & المجموع \\
\hline \multirow{4}{*}{ 'الْ } & \multirow{4}{*}{$r 0 . \leqslant \leqslant r$} & & & & أسباب اقتصـادية \\
\hline & & $r$ & 1.4 .199 & Y.V.V9V & بين المجمو عات \\
\hline & & $11 \mathrm{~V}$ & $\varepsilon . \wedge \varepsilon \cdot$ & $\varepsilon \vee \vee . \vee q \varepsilon$ & داخل المجمو عات \\
\hline & & 119 & & $710.09 r$ & المجموع \\
\hline \multirow{4}{*}{ غير دال } & \multirow{4}{*}{$1 . \sum Y \wedge$} & & & & أسباب نفسية \\
\hline & & r & $19 . \wedge r 7$ & rq.TVY & بين المجمو عات \\
\hline & & $11 \mathrm{~V}$ & $1 \% . \wedge 9$. & 1710.07 & داخل المجمو عات \\
\hline & & 119 & & $177 \leqslant . \vee \leqslant 1$ & المجموع \\
\hline
\end{tabular}

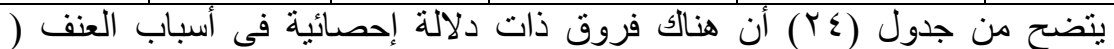

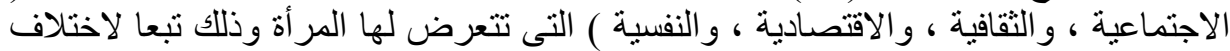

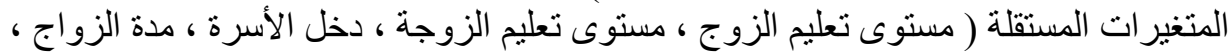

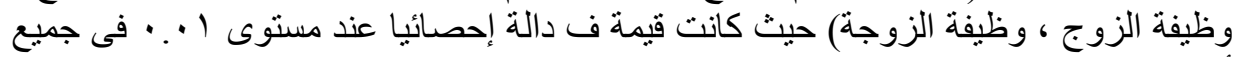

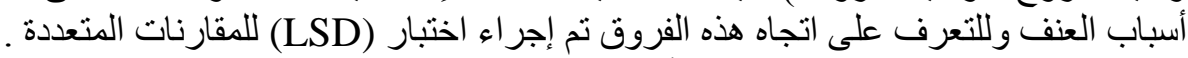

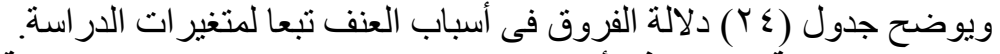

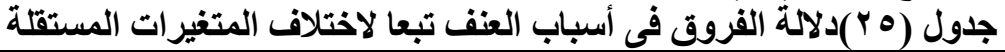

\begin{tabular}{|c|c|c|c|}
\hline 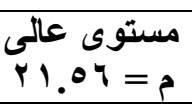 & 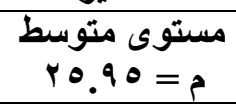 & 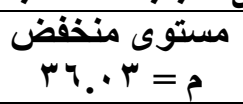 & الأسباب الإجتماعية \\
\hline & & & تعليم الزوج : \\
\hline & - & - & مستوى منخفض \\
\hline & - & $* *) \cdot . \wedge$ & مستوى متوسط \\
\hline- & $* * \leqslant . \mu q$ & $* * \mid \leq . \leq V$ & مستوى عالى \\
\hline \multirow[t]{6}{*}{ 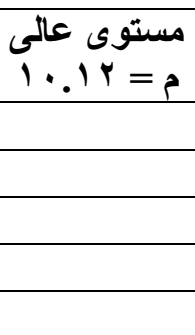 } & مستوى متوسط 19.79 & مستوى منخفض & الأسباب الثقافية \\
\hline & & - & مستوى منخفض \\
\hline & - & $* * \varepsilon .1 T$ & مستوى متوسط \\
\hline & $* * 7.0 \mathrm{~V}$ & $* * 1, V$. & مستوى عالى \\
\hline & & - & مستوى منخفض \\
\hline & - &. .70 & مستوى متوسط \\
\hline- & **r.r & $* * r .9 V$ & مستوى عالى \\
\hline \multirow[t]{3}{*}{ 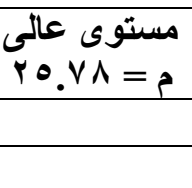 } & 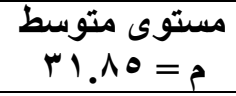 & 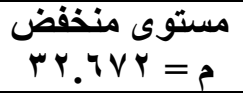 & الأسباب النفسية \\
\hline & & - & مستوى منخفض \\
\hline & - & $\because \wedge Y I$ & مستوى متوسط \\
\hline
\end{tabular}




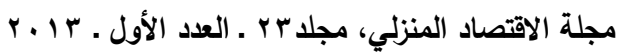

\begin{tabular}{|c|c|c|c|}
\hline- & $* *\urcorner . \vee V$ & $* * 7 . \wedge 9$ & مستوى عالى \\
\hline \multirow[t]{4}{*}{ مستوى ع عالى } & 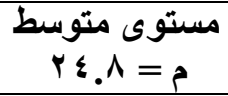 & 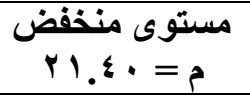 & الأسباب الإجتماعية \\
\hline & & & تعليم الزوجة : \\
\hline & - & - & مستوى منخفض \\
\hline & - & $* Y .7 \wedge$ & مستوى متوسط \\
\hline- & $* * q . \vee 0$ & *IY. $\leqslant \varepsilon$ & مستوى عالى \\
\hline \multirow[t]{4}{*}{ 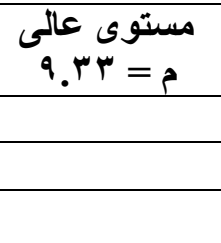 } & 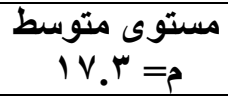 & 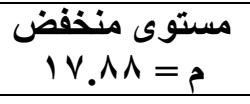 & الأسباب الثقافية \\
\hline & & - & مستوى منخفض \\
\hline & - & $\cdot .29$ & مستوى متوسط \\
\hline & $* * \Lambda .0$ & $* * \wedge .00$ & مستوى عالى \\
\hline \multirow[t]{3}{*}{ 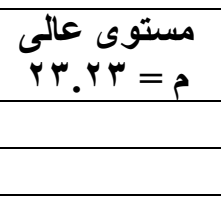 } & مستوى متوسط = م.اب & 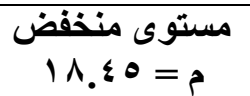 & الأسباب الاقتصادية \\
\hline & & - & مستوى منخفض \\
\hline & - & $* \Gamma . \Gamma \leq$ & مستوى متوسط \\
\hline- & $* 1 . \leqslant Y$ & $* * \varepsilon . V \vee$ & مستوى عالى \\
\hline \multirow[t]{3}{*}{ 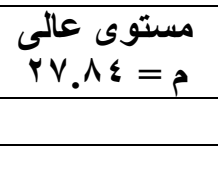 } & 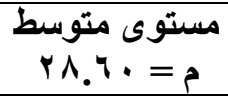 & 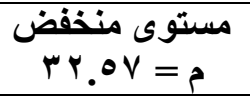 & الأسباب النفسية \\
\hline & & - & مستوى منخفض \\
\hline & - & $* * Y .97$ & مستوى متوسط \\
\hline- & $\because \vee 7$ & $* * \xi . V Y$ & مستوى عالى \\
\hline \multirow[t]{4}{*}{ 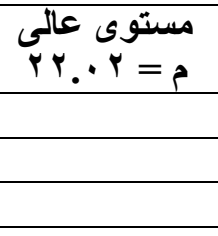 } & مستوى متوسط = ا. ب ب & 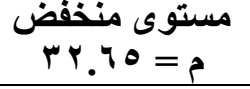 & الأسباب الإجتماعية \\
\hline & & & مستوى دخل الأسرة : \\
\hline & - & - & مستوى منخفض \\
\hline & - & $* * 7.0$. & مستوى منوسط \\
\hline- & $* * \xi . I T$ & $* * 1 \cdot .7 r$ & مستوى مرتفع \\
\hline \multirow[t]{4}{*}{ 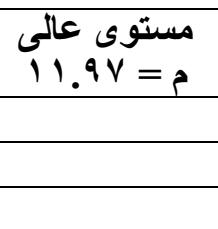 } & 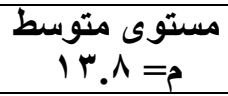 & 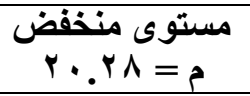 & الأسباب الثقافية \\
\hline & & - & مستوى منخفض \\
\hline & - & $* * 7 . \leqslant 0$ & مستوى متوسط \\
\hline & $* 1 . \wedge 0$ & $* * \wedge . \Gamma$ & مستوى مرتفع \\
\hline \multirow[t]{3}{*}{ 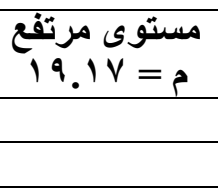 } & 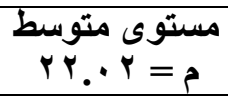 & 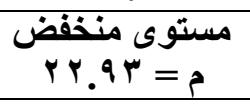 & الأسباب الاقتصادية \\
\hline & & - & مستوى منخفض \\
\hline & - & $* .917$ & مستوى متوسط \\
\hline- & $* * r . \wedge 0$ & $* * \Gamma . \vee\urcorner$ & مستوى مرتفع \\
\hline مستوى عالى & مستوى منوسط & مستوى منخفض & الأسباب النفسية \\
\hline
\end{tabular}




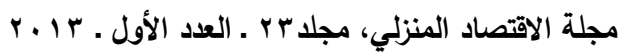

\begin{tabular}{|c|c|c|c|}
\hline$T V . I T=\rho$ & $r \cdot .1 \cdot=?$ & $\Gamma . V I=$ ? & \\
\hline & & - & مستوى منخفض \\
\hline & - & $* 1.71$ & مستوى متوسط \\
\hline- & $* * Y .9 \wedge$ & $* * \Sigma .09$ & مستوى مرتفع \\
\hline \multirow[t]{4}{*}{ 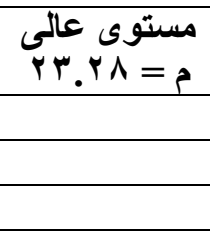 } & $\begin{array}{c}\text { مستوى متوسط = } \\
\text { rV.VV }\end{array}$ & 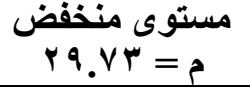 & الأسباب الإجتماعية \\
\hline & & & وظيفة الزوج : \\
\hline & - & - & مستوى منخفض \\
\hline & - & 1.90 & مستوى متوسط \\
\hline- & $* * \varepsilon . \varepsilon \wedge$ & $* * 7 . \leqslant \leqslant$ & مستوى عالى \\
\hline \multirow[t]{3}{*}{ 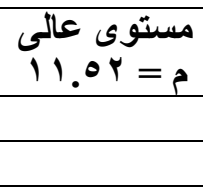 } & 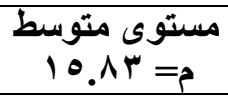 & 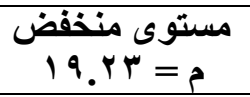 & الأسباب الثقافية \\
\hline & & - & مستوى منخفض \\
\hline & - & $* * r . r q$ & مستوى متوسط \\
\hline - & **ะ, r! & $* * \vee . \vee$ & مستوى عالى \\
\hline \multirow[t]{4}{*}{ 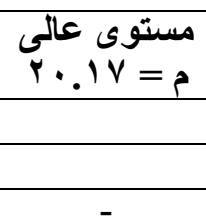 } & 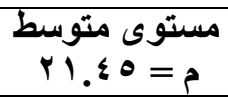 & 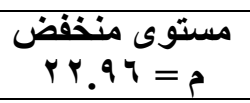 & الأسباب الاقتصادية \\
\hline & & - & مستوى منخفض \\
\hline & - & $* 1.0$. & مستوى متوسط \\
\hline & $* 1 . Y \wedge$ & $* * Y . \vee \wedge$ & مستوى عالى \\
\hline \multirow[t]{3}{*}{ 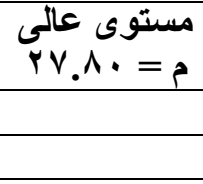 } & مستوى متوسط & 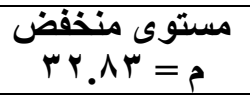 & الأسباب النفسية \\
\hline & & - & مستوى منخفض \\
\hline & - & $* * Y . \vee \wedge$ & مستوى متوسط \\
\hline- & $* 1 . \vee 9$ & $* * \varepsilon .0 \wedge$ & مستوى عالى \\
\hline \multirow[t]{4}{*}{ 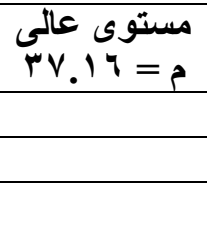 } & 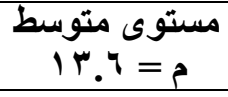 & 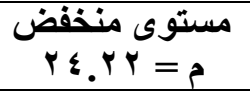 & الأسباب الإجتماعية \\
\hline & & & وظيفة الزوجة : \\
\hline & - & - & مستوى منخفض \\
\hline & - & $* * V . \leq 0$ & مستوى متوسط \\
\hline- & $* * 0 . \Sigma \wedge$ & $* * 1 \Gamma .9 \leq$ & مستوى عالى \\
\hline \multirow[t]{3}{*}{ 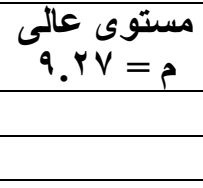 } & 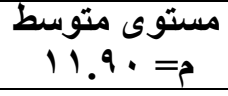 & 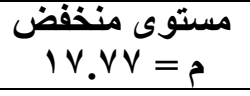 & الأسباب الثقافية \\
\hline & & - & مستوى منخفض \\
\hline & - & $* * 0 . \wedge 7$ & مستوى متوسط \\
\hline- & $* r .7 r$ & $* * \wedge .0$ & مستوى عالى \\
\hline \multirow[t]{2}{*}{ 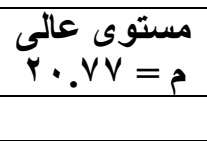 } & 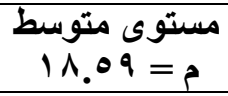 & 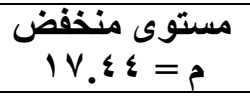 & الأسباب الاقتصادية \\
\hline & & - & مستوى منخفض \\
\hline
\end{tabular}




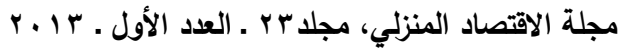

\begin{tabular}{|c|c|c|c|}
\hline & - & $1.1 \varepsilon$ & مستوى متوسط \\
\hline- & $* * Y .1 \wedge$ & **Y.rT & مستوى عالى \\
\hline \multirow[t]{3}{*}{ 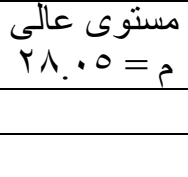 } & 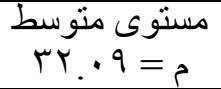 & 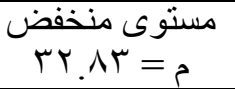 & الأسباب النفسية \\
\hline & & - & مستوى منخفض \\
\hline & - & $\because \vee 9$ & مستوى متو سط \\
\hline- & $* * \xi . \cdot r$ & $* * \xi . \wedge r$ & مستوى عالى \\
\hline \multirow[t]{5}{*}{ 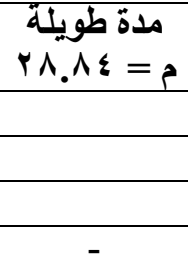 } & مدة متوسطة +... & مدة قصتيزة & الأسباب الإجتماعية \\
\hline & & & مدة الزواج : \\
\hline & - & - & مدة قصيرة \\
\hline & - & $* * \varepsilon .9$. & مدة متوسط \\
\hline & $* Y . \wedge \Sigma$ & $* * \vee . \vee 0$ & مدة طويلة \\
\hline \multirow[t]{3}{*}{ 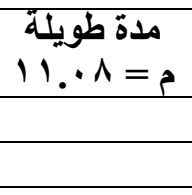 } & 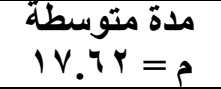 & 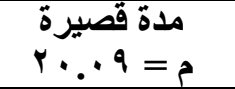 & الأسباب الثقافية \\
\hline & - & - & مدة قصبرة \\
\hline & - & $* * Y . \leqslant 7$ & مدة متوسط \\
\hline- & **ๆ.0r & $* * q .$. & مدة طويلة \\
\hline \multirow[t]{3}{*}{ 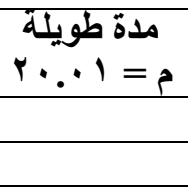 } & 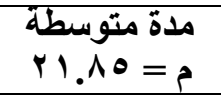 & 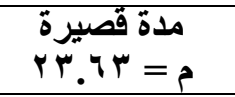 & الأسباب الاقتصادية \\
\hline & - & - & مدة قصيرة \\
\hline & - & $* * 1 . \vee \wedge$ & مدة متوسط \\
\hline - & $* 1 . \wedge \Gamma$ & $* * \Gamma .71$ & مدة طو يلة \\
\hline
\end{tabular}

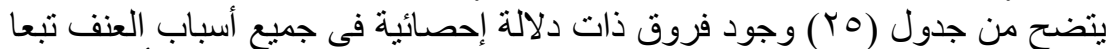

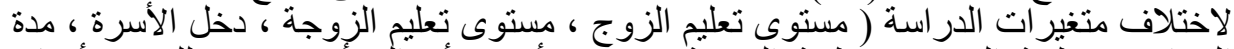

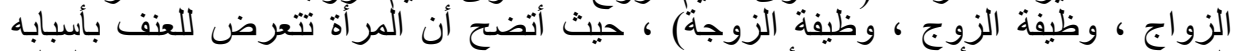

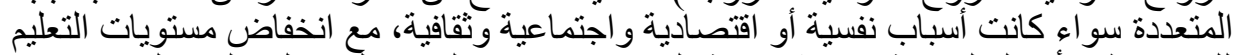

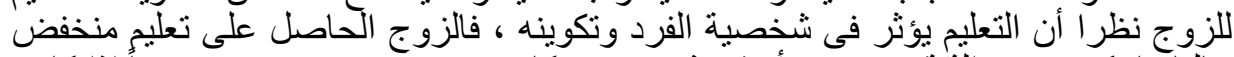

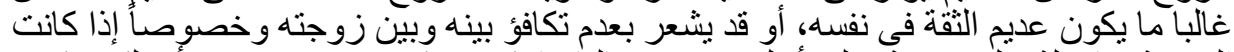

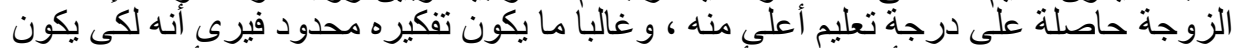

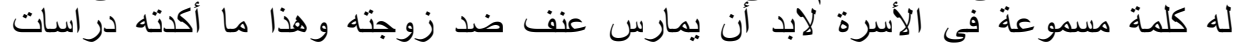

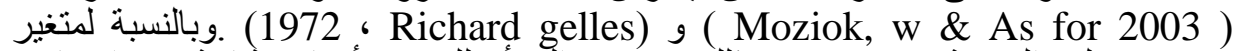

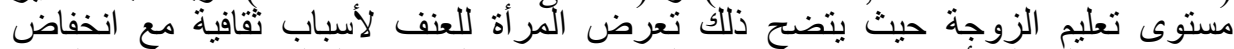

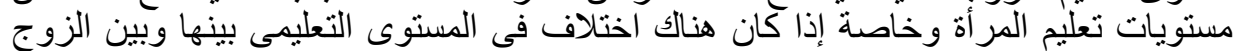

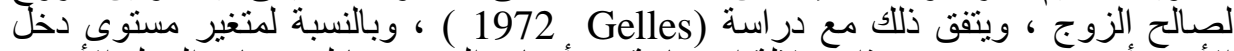

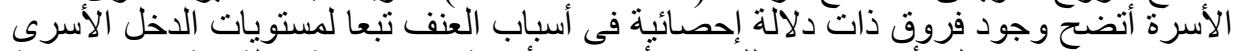

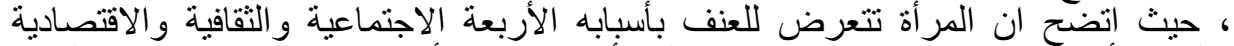

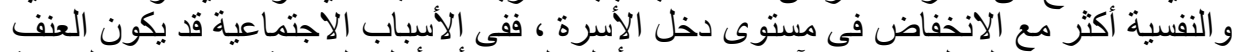

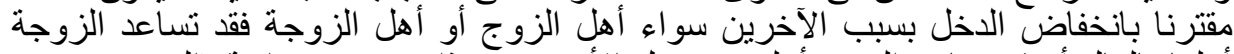

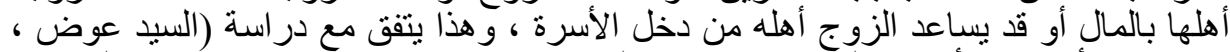

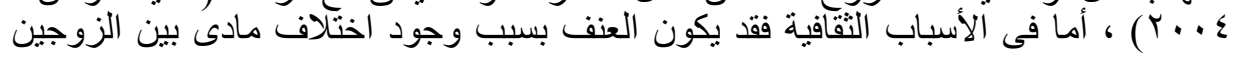




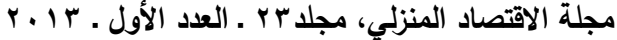

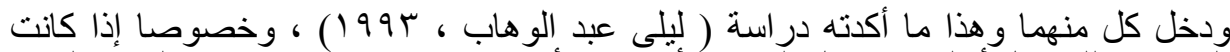

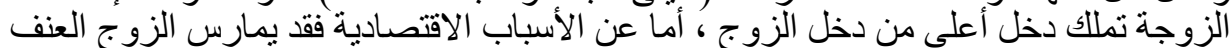

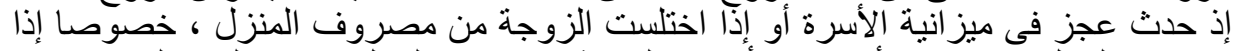

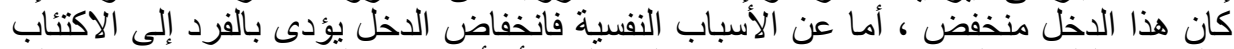

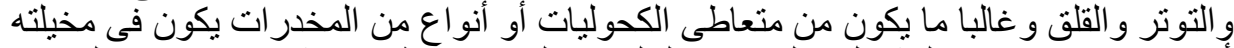

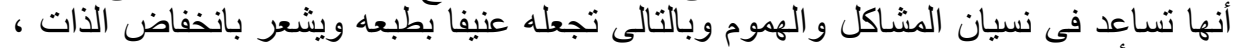

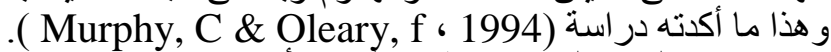

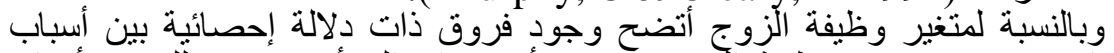

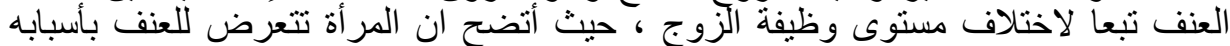

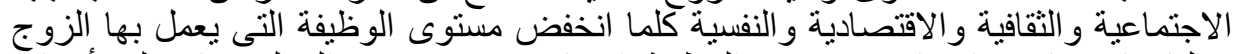

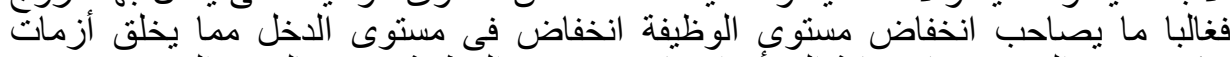

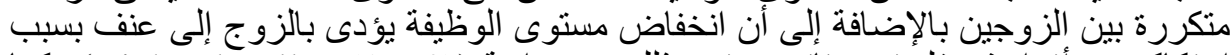

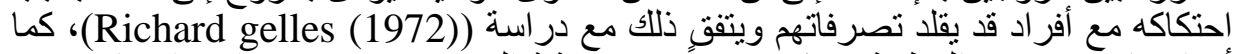

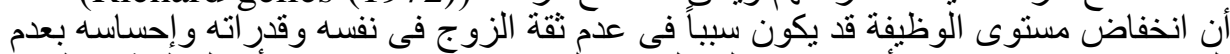

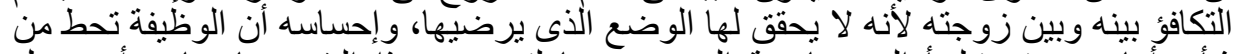

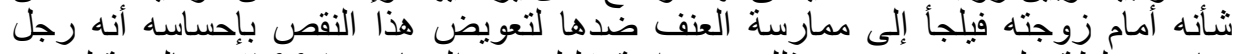

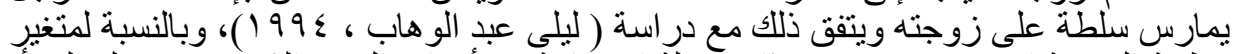

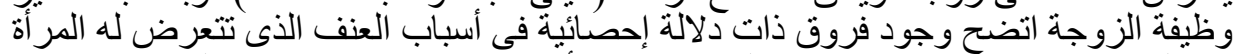

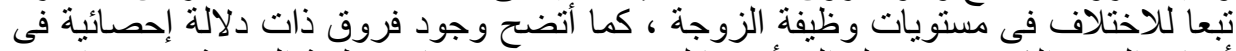

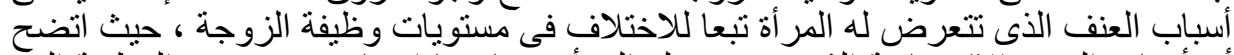

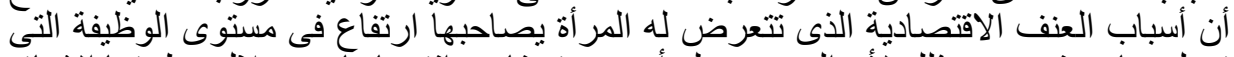

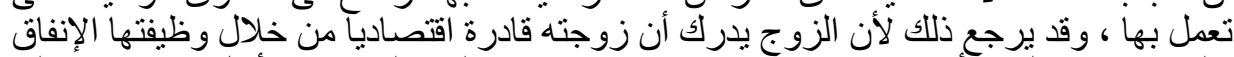

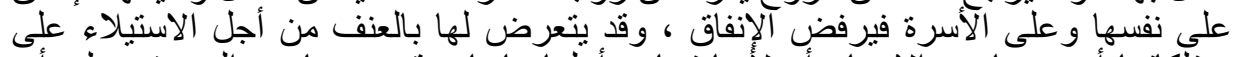

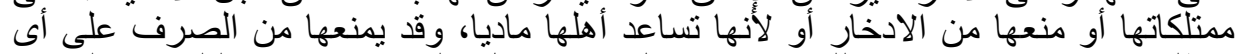

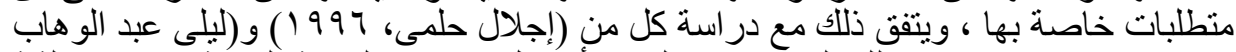

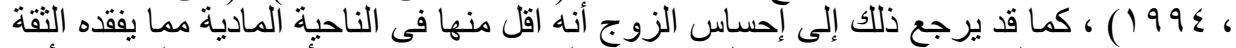

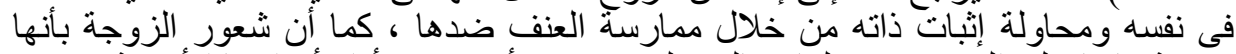

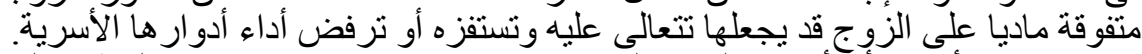

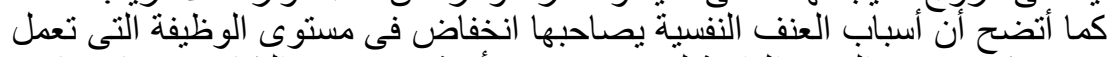

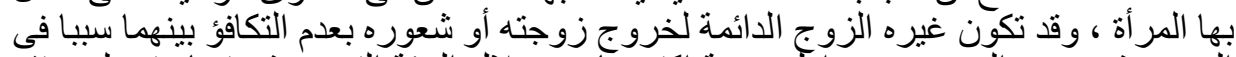

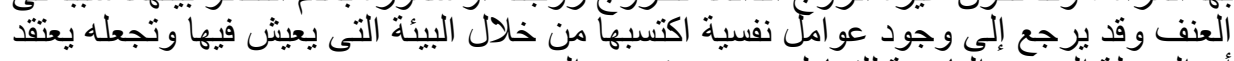

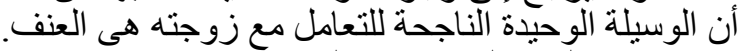

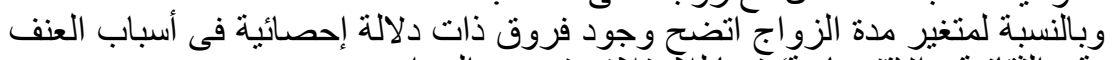

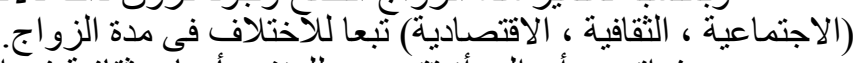

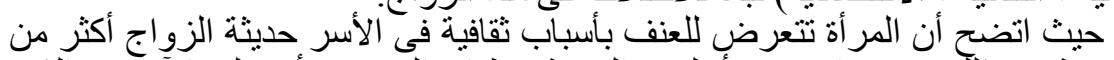

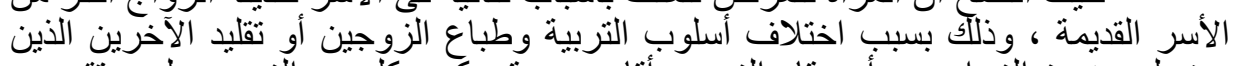

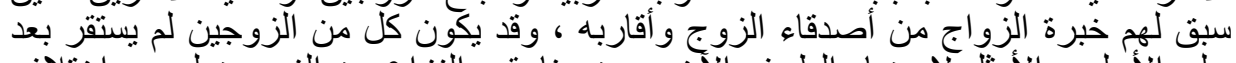

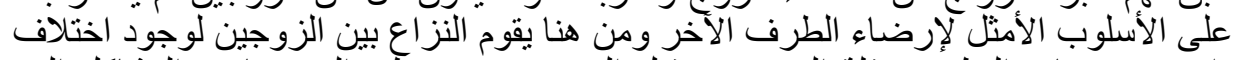

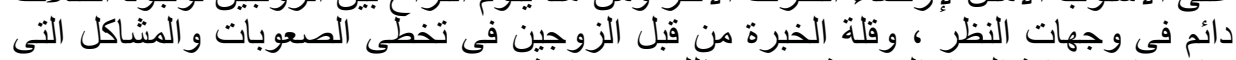

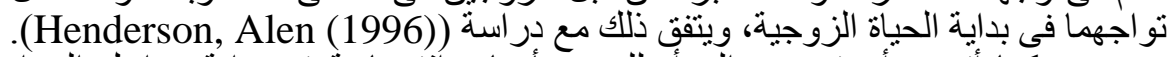

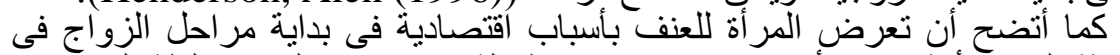

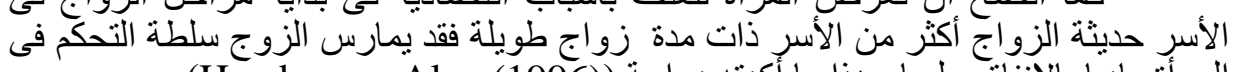

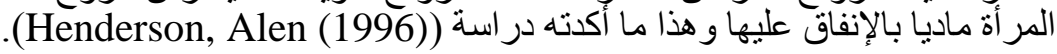




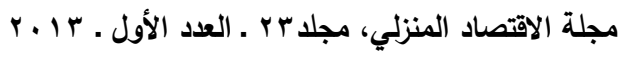

ومما سبق يتضح وجود فروق فى أسباب العنف الذى تتعرض له المرأة من قبل

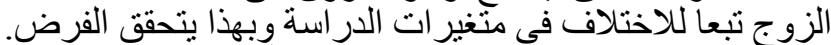

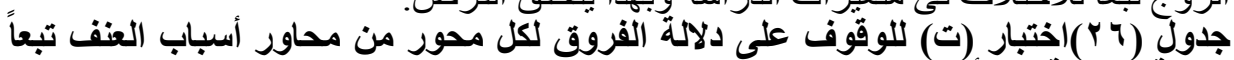

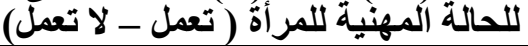

\begin{tabular}{|c|c|c|c|c|c|c|}
\hline الدلالة & قيمة (ت) & الحرجية & العينة & الالحيارى اف & الحستوسط & اجتماعية \\
\hline \multirow{2}{*}{ لصالح تعمل } & \multirow{2}{*}{9.001} & \multirow{2}{*}{111} & $\leqslant 9$ & $\Lambda .1 \leqslant r$ & TY.rYT & تعمل \\
\hline & & & VI & T.TY & $r Y . \varepsilon r V$ & لا تعمل \\
\hline الدلالة & قيمة (ت) & الحرجية & العينة & الالحعراف & الحسابى الحسط & أسباب ثقافية \\
\hline \multirow{2}{*}{ لصالح لا تعمل } & \multirow{2}{*}{$7.0 Y V$} & \multirow{2}{*}{111} & $\leqslant 9$ & E.AYIYY & $T_{.} \cdot r_{\cdot} \varepsilon$ & تعمل \\
\hline & & & VI & r.Tr & 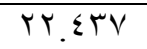 & لا تعمل \\
\hline الدلالة & قيمة (ت) & الحرية & العينة & الانحراف & الحسابى الحط & أقتصادية \\
\hline \multirow{2}{*}{ لصالح لُ اتعمل } & \multirow{2}{*}{11.099} & \multirow{2}{*}{111} & $\leqslant 9$ & r.Y & $19.11 \varepsilon$ & تعمل \\
\hline & & & VI & 1.011 & TY. $\leqslant 70$ & لا تعمل \\
\hline الدلالة & قيمة (ت) & الحرجية & العينة & الالحيارى اف & الحسابى الحط & أسباب نفسية \\
\hline \multirow{2}{*}{ لصالح تُعمل } & \multirow{2}{*}{5.111} & \multirow{2}{*}{111} & $\leq 9$ & $\varepsilon .197$ & $r \cdot . v 00$ & تعمل \\
\hline & & & VI & $r .|\gamma| .0$ & YA.TTY. & لا تعمل \\
\hline
\end{tabular}

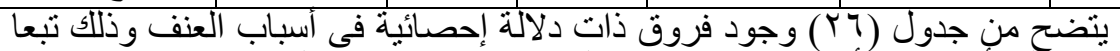

للحالة المهنية للمر أنة وهى الأسباب الاجتماعية و الثقافية وألاقتصأدية و النفسية حيث كانت قيمة

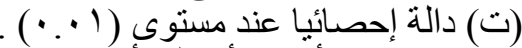

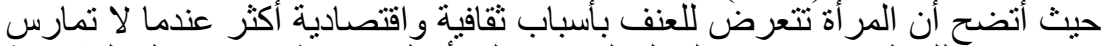

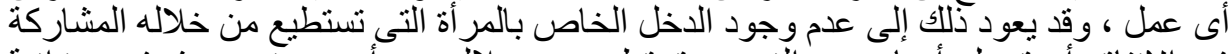

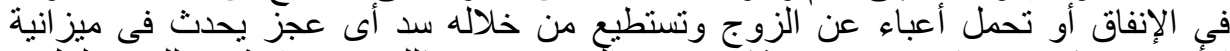

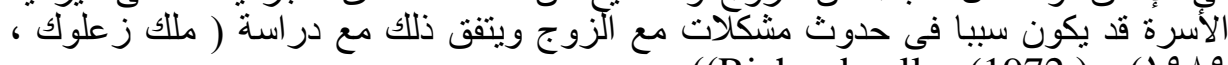

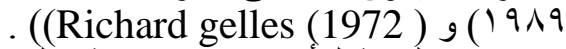

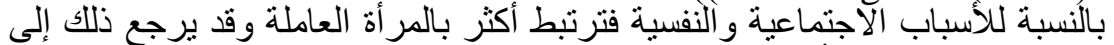

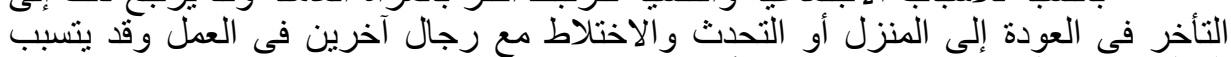

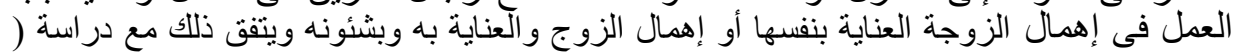

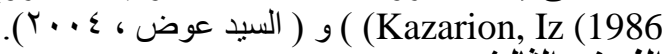

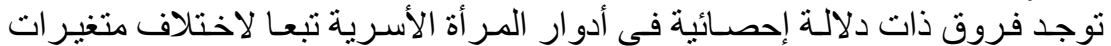

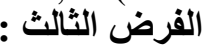

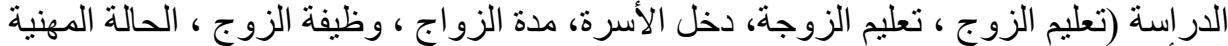

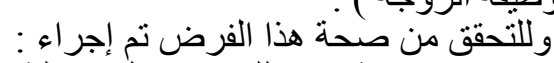

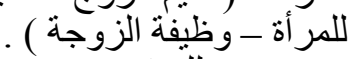

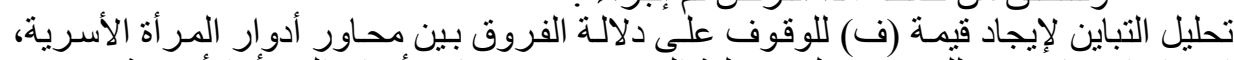

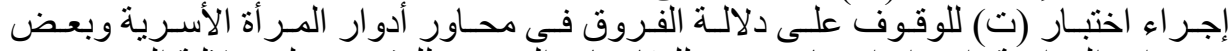

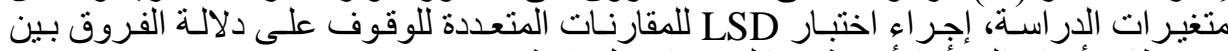

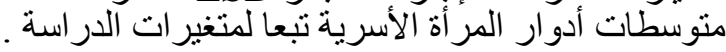




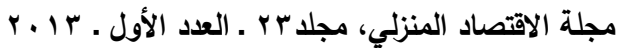

ويوضح جدول (YV) دلالة الفروق فى أدو ار المر أة الأسرية تبعا لاختلاف متغير ات الدراسة .

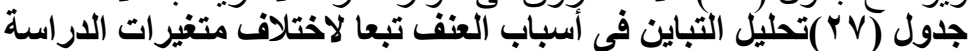

\begin{tabular}{|c|c|c|c|c|c|}
\hline الدلالة & قيمة (ف) & دالحرية & المربعات & المربعات & مصدر التباين \\
\hline & & & & & تعليم الزوج : \\
\hline \multirow{4}{*}{ دالز } & \multirow{4}{*}{$7 ะ . \wedge 9 \vee$} & & & & دور الامم \\
\hline & & $r$ & 11.01 .100 & 17118.011 & بين المجمو عات \\
\hline & & $11 \mathrm{~V}$ & YVA.YTV & rYOOV.YAq & داخل المجمو عات \\
\hline & & 119 & & 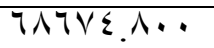 & المجموع \\
\hline \multirow{4}{*}{ 'ُ دالز } & \multirow{4}{*}{$7 \cdot \leq T V$} & & & & دور الزوجة \\
\hline & & r & 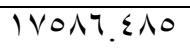 & rolVT.9V. & بين المجمو عات \\
\hline & & $11 \mathrm{~V}$ & $r q \cdot . \wedge \leqslant 0$ & $\Gamma \xi \cdot Y \wedge . \wedge T !$ & داخل المجمو عات \\
\hline & & 119 & & $79 r .1 . V 9 r$ & المجموع \\
\hline \multirow{4}{*}{ دال• } & \multirow{3}{*}{$\leqslant 0 . \Gamma \wedge \wedge$} & & & & دور ربة منزل \\
\hline & & $r$ & V971.IVV & $10947 . r 04$ & بين المجمو عات \\
\hline & & 118 & 1100.007 & $r \cdot 0 \leqslant \cdot .1 T$ & داخل المجمو عات \\
\hline & & 119 & & rาะVI.MTV & المجموع \\
\hline \multirow{5}{*}{ دالز } & \multirow{4}{*}{$0 \wedge$. YOO } & & & & دور النو احى الاجتماعية \\
\hline & & $r$ & $\leq \vee Y q .7 \leq \Lambda$ & $9 \leq 09.19 \mathrm{~V}$ & بين المجمو عات \\
\hline & & $11 \mathrm{~V}$ & $\wedge ! .1 \wedge \wedge$ & $9 \leq 99 . .99$ & داخل المجمو عات \\
\hline & & 119 & & I^90^.r.7 & المجموع \\
\hline & & & & & تعليم الزوجة : \\
\hline \multirow{4}{*}{ 'ُ دال: } & \multirow{4}{*}{$7 r . \wedge 91$} & & & & دور الأم \\
\hline & & $r$ & $Y \cdot Y \cdot I . V \leq V$ & $\varepsilon \cdot \varepsilon \cdot r . \leqslant 9 r$ & بين المجمو عات \\
\hline & & $11 \mathrm{~V}$ & 117.191 & एч99ะ. MVE & داخل المجمو عات \\
\hline & & 119 & & VVTฯV.АTV & المجموع \\
\hline \multirow{4}{*}{ '•• } & \multirow{4}{*}{49.790} & & & & دور الزوجة \\
\hline & & $r$ & $1 \leq 17.99 \leqslant$ & rq7וr.911 & بين المجمو عات \\
\hline & & $11 \mathrm{~V}$ & ะ91.7หq & 0^Mrq.7. & داخل المجمو عات \\
\hline & & 119 & & NV90Y.09Y & المجموع \\
\hline \multirow{4}{*}{ دالز } & \multirow{4}{*}{$r \varepsilon .1 V T$} & & & & دور ربة منزل \\
\hline & & $r$ & एะフА. YTr & 7917.010 & بين المجمو عات \\
\hline & & $11 \mathrm{~V}$ & $1 \leqslant \Gamma . \leqslant \wedge 0$ & I フVAV.A.. & داخل المجمو عات \\
\hline & & 119 & & TMVYE.TYO & المجموع \\
\hline \multirow{5}{*}{ '•• } & \multirow{3}{*}{$\varepsilon r . \Upsilon \wedge \wedge$} & & & & دور النواحى الاجتماعية \\
\hline & & $r$ & $5070.1 \mathrm{VI}$ & $q 1 r \cdot r \leq r$ & بين المجمو عات \\
\hline & & $11 \mathrm{~V}$ & $1 \cdot 8.799$ & $1 Y 7 \ldots . V V T$ & داخل المجمو عات \\
\hline & & 119 & & YIVTI.IIT & المجموع \\
\hline & & & & & دخل الاسرة : \\
\hline \multirow{2}{*}{ '•• } & \multirow{2}{*}{$\varepsilon .017$} & & & & دور الام \\
\hline & & $r$ & 1109.910 & YMIAI.AV. & بين المجمو عات \\
\hline
\end{tabular}




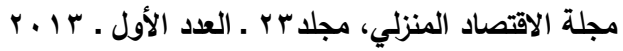

\begin{tabular}{|c|c|c|c|c|c|}
\hline & & $11 \mathrm{~V}$ & TAT.・10 & $T \Gamma \leqslant V 1.997$ & داخل المجمو عات \\
\hline & & 119 & & $0770 \% . \wedge 7 V$ & المجموع \\
\hline \multirow{4}{*}{ 'ُ دالْ } & \multirow{3}{*}{70.707} & & & & دور الزوجة \\
\hline & & T & $r r 010.1 \mathrm{VI}$ & $\varepsilon V \cdot r \cdot \Gamma \leqslant \mu$ & بين المجمو عات \\
\hline & & $11 \mathrm{~V}$ & rod.109 & $\varepsilon 19 . \leq .7 \leqslant 9$ & داخل المجمو عات \\
\hline & & 119 & & 1194ะ.991 & المجموع \\
\hline \multirow{3}{*}{ 'دانْ } & \multirow{3}{*}{$r r_{.} \cdot 11$} & & & & دور ربة منزل \\
\hline & & r & 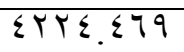 & $\Lambda \varepsilon \varepsilon \Lambda .9 \Gamma \Lambda$ & بين المجمو عات \\
\hline & & $11 \mathrm{~V}$ & $1 T 1.7 \wedge r$ & 105.7 .919 & داخل المجمو عات \\
\hline \multirow{6}{*}{ 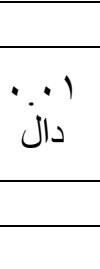 } & & 119 & & Tr100.1TV & المجموع \\
\hline & \multirow{3}{*}{.711} & & & & دور النو احى الاجتماعية \\
\hline & & r & $9 V .07$ & $19 \varepsilon .11$ & بين المجمو عات \\
\hline & & $11 \mathrm{~V}$ & $10 \wedge .9 \vee 7$ & $|\wedge 7 \cdot . Y| \leq$ & داخل المجمو عات \\
\hline & & 119 & & IAVQS.TYO & المجموع \\
\hline & & & & & مدة الزواج : \\
\hline \multirow{3}{*}{ 'دانْ } & \multirow{3}{*}{ ro.rq9 } & & & & دور الام \\
\hline & & $r$ & $1 . v 9 \cdot .1 \leqslant r$ & YIOA. YAT & بين المجمو عات \\
\hline & & $11 \mathrm{~V}$ & $\Gamma \cdot \Sigma . \wedge 川 1$ & ro77r.9)ร & داخل المجمو عات \\
\hline & & 119 & & OVYET.Y.. & المجموع \\
\hline \multirow{4}{*}{ ' دانْ } & \multirow{4}{*}{$1 \% .71}$. & & & & دور الزوجة \\
\hline & & t & $T Y V \wedge .91 Y$ & TYOOV.AYO & بين المجمو عات \\
\hline & & $11 \mathrm{~V}$ & $\varepsilon 09 . \ldots$ & $0 Y V \cdot Y .97 V$ & داخل المجمو عات \\
\hline & & 119 & & $77 Y 7 . . \mathrm{VYr}$ & المجموع \\
\hline \multirow{4}{*}{ 'الْ } & \multirow{4}{*}{$|r . \mu| \leq$} & & & & دور ربة منزل \\
\hline & & $r$ & r19r.క71 & 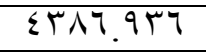 & بين المجمو عات \\
\hline & & $11 \mathrm{~V}$ & $17 \leqslant .10 \leqslant$ & 19YV7.Y7E & داخل المجمو عات \\
\hline & & 119 & & rrרזr.Y.. & المجموع \\
\hline \multirow{5}{*}{ 'دآن } & \multirow{3}{*}{ r.. rq. } & & & & دور النواحسالاجتماعية \\
\hline & & $r$ & 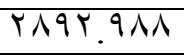 & $0 \vee 10.9 \vee 7$ & بين المجمو عات \\
\hline & & $11 \mathrm{~V}$ & $11 \cdot . \cdot \varepsilon r$ & 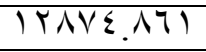 & داخل المجمو عات \\
\hline & & 119 & & 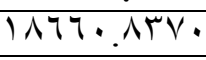 & المجموع \\
\hline & & & & & وظيفة الزوج : \\
\hline \multirow{4}{*}{ 'الْ } & \multirow{3}{*}{$11.10 \leqslant$} & & & & دور الامم \\
\hline & & t & $20.1 .09 Y$ & q..r.IAr & بين المجمو عات \\
\hline & & $11 \mathrm{~V}$ & $\varepsilon \cdot T . O V \cdot$ & EVYIV.VEY & داخل المجمو عات \\
\hline & & 119 & & OTYY..9YO & المجموع \\
\hline \multirow{4}{*}{ 'الْ } & \multirow{4}{*}{$7 . .001$} & & & & دور الزوجة \\
\hline & & $r$ & TVAEI.TYV & TOTAY.YOT & بين المجمو عات \\
\hline & & $11 \mathrm{~V}$ & Y9ะ.707 & $r \varepsilon \leqslant \vee \leqslant . V \Psi q$ & داخل المجمو عات \\
\hline & & 119 & & $V .10 V .99 Y$ & المجموع \\
\hline
\end{tabular}




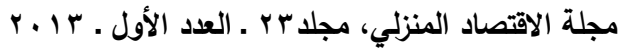

\begin{tabular}{|c|c|c|c|c|c|}
\hline \multirow{3}{*}{ دآل } & \multirow{3}{*}{$1 . \cdot \varepsilon \wedge$} & & & & دور ربة منزل \\
\hline & & T & $T .9 .01 \mathrm{~V}$ & $\varepsilon 19 .+\mu r$ & بين المجمو عات \\
\hline & & $11 \mathrm{~V}$ & 199.177 & TMTAE.YTV & داخل المجمو عات \\
\hline & & 119 & & rMA.r.r.. & المجموع \\
\hline \multirow{5}{*}{ 'الن } & \multirow{3}{*}{ OV.V.q } & & & & دور النو احى الاجتماعية \\
\hline & & $r$ & $0 \mathrm{Y00} .70 \mathrm{~V}$ & $1.011 .41 \varepsilon$ & بين المجمو عات \\
\hline & & $11 \mathrm{~V}$ & $91 . \cdot V Y$ & 1.700 .5 .7 & داخل المجمو عات \\
\hline & & 119 & & YII77.VY. & المجموع \\
\hline & & & & & وظيفة الزوجة : \\
\hline \multirow{4}{*}{ 'دانز } & \multirow{3}{*}{$1 \leqslant .01 Y$} & & & & دور الام \\
\hline & & r & r19r.VV7 & $\varepsilon T \wedge V .001$ & بين المجمو عات \\
\hline & & $\leqslant 7$ & $101.1 V \varepsilon$ & $790 \leq \ldots$ & داخل المجمو عات \\
\hline & & $\varepsilon \wedge$ & & $11 r \leqslant 1.001$ & المجموع \\
\hline \multirow{3}{*}{ 'دان } & \multirow{3}{*}{$1 \leqslant .000$} & & & & دور الزوجة \\
\hline & & $r$ & $T \leq 17.79 Y$ & ENTY.r人O & بين المجمو عات \\
\hline & & $\varepsilon 7$ & VITV & VITV.VIV & داخل المجمو عات \\
\hline & & $\sum \Lambda$ & & $T Y \sum V I .1 \cdot T$ & المجموع \\
\hline \multirow{4}{*}{ غآل } & \multirow{3}{*}{.711} & & & & دور ربة منزل \\
\hline & & t & Tr9.0Y. & ro9.. \&1 & بين المجمو عات \\
\hline & & $\varepsilon 7$ & $Y \cdot 9 . \sum 199$ & 9747.01. & داخل المجمو عات \\
\hline & & $\leqslant 1$ & & 9190.001 & المجموع \\
\hline \multirow{4}{*}{ 'دانْ } & \multirow{3}{*}{$1 r .10 \mathrm{~V}$} & & & & دور النواحى الاجتماعية \\
\hline & & $r$ & $1 M 99 . \wedge Y T$ & rV99.7 17 & بين المجمو عات \\
\hline & & $\varepsilon 7$ & $1 \cdot 1.11$ & $\varepsilon 7 \leqslant 7 . \wedge \leqslant \Gamma$ & داخل المجمو عات \\
\hline & & $\leqslant 1$ & & $V \leqslant \leqslant 7 . \leqslant 9$. & المجموع \\
\hline
\end{tabular}

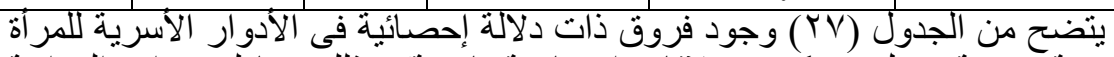

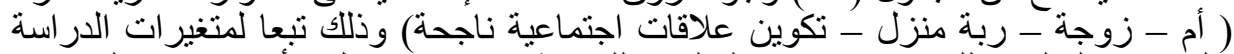

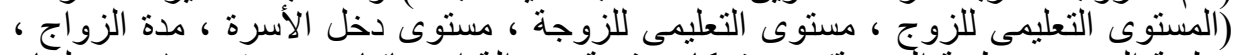

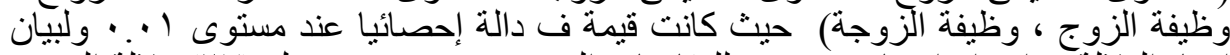

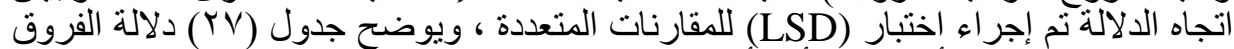

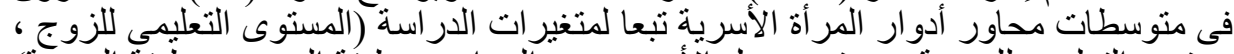

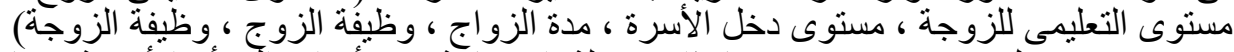

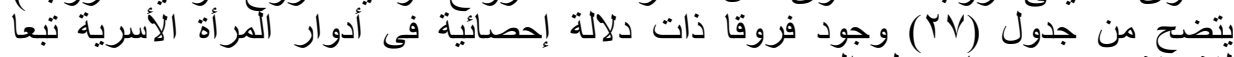

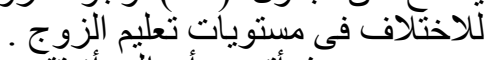

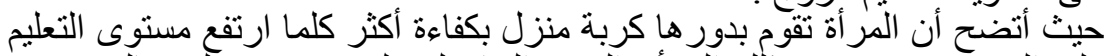

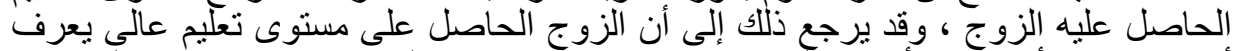

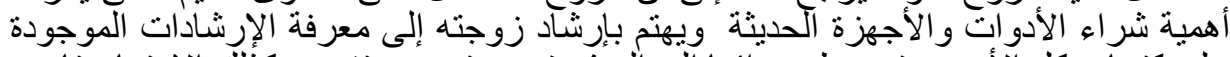

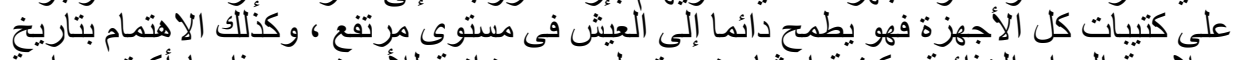

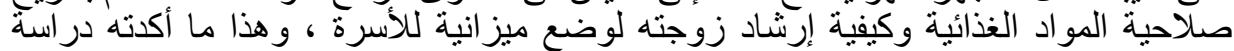

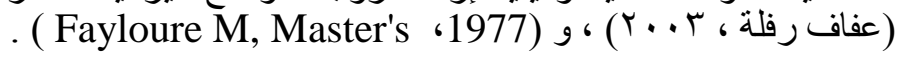




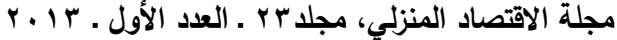

كما أتضح أن المر أة تكون شبكة علاقات اجتماعية ناجحة أكثر كلما انخفض المستوى

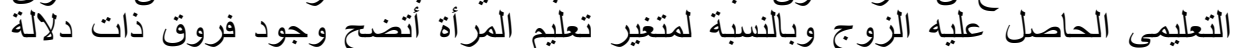

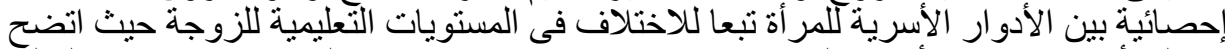

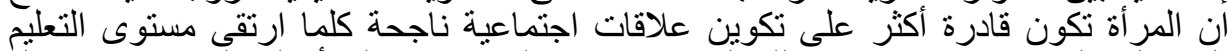

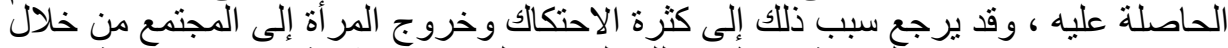

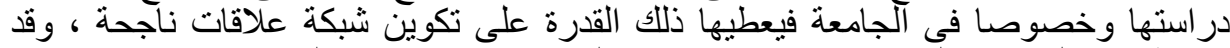

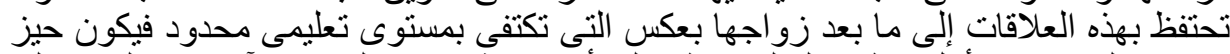

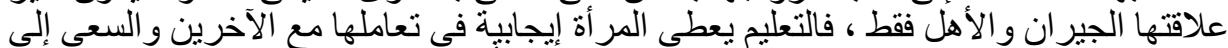

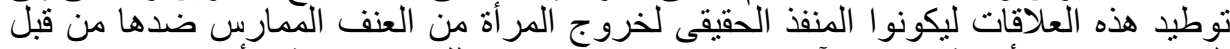

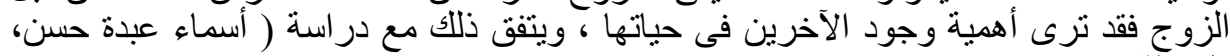

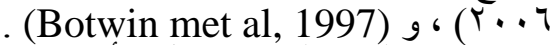
وبالنسبة لمتغير دخل الأسرة تبين من الجدول وجود فروق ذات دلالة إحصائية بين

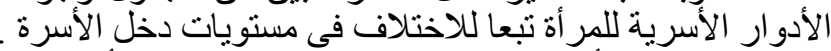

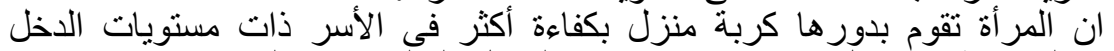

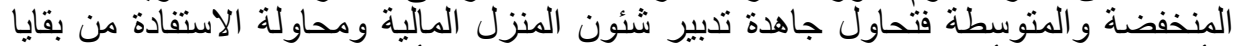

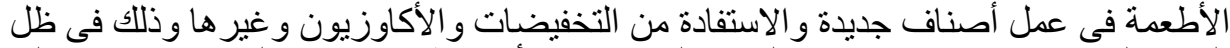

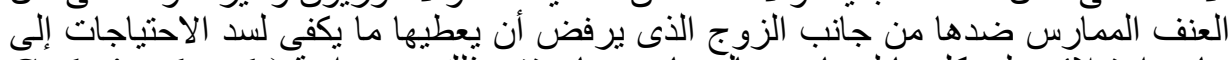

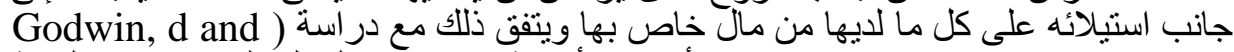
Konnce

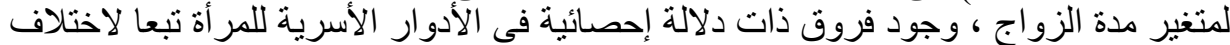

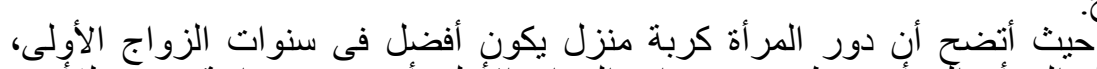

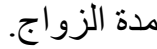

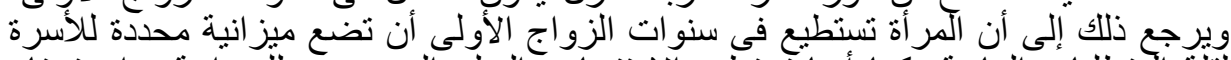

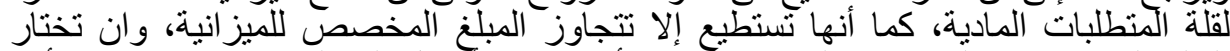

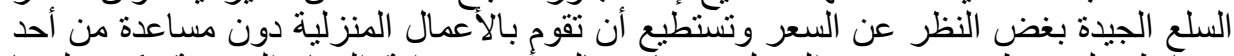

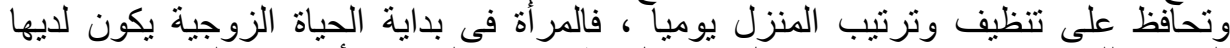

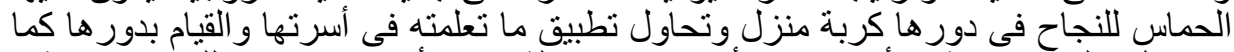

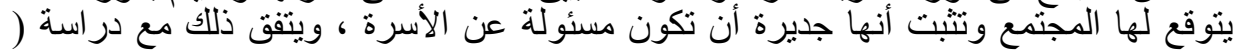
. ( Gofwin, d and Konnce ، 1992

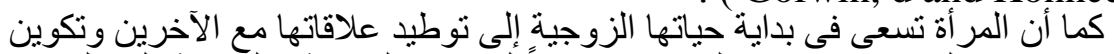

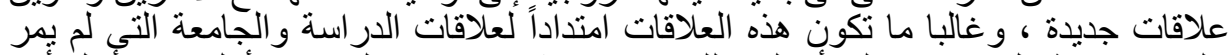

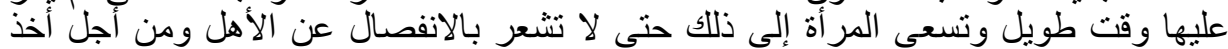

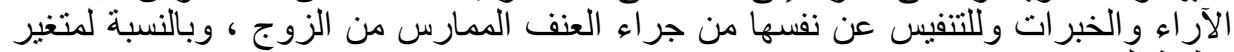

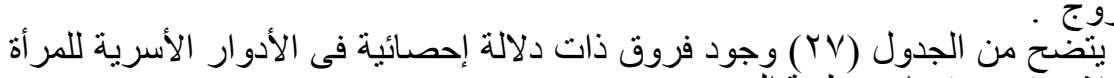

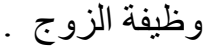

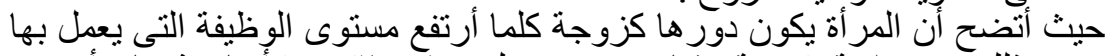

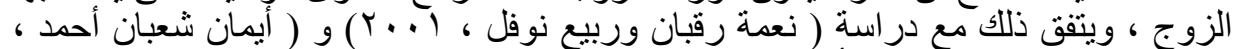

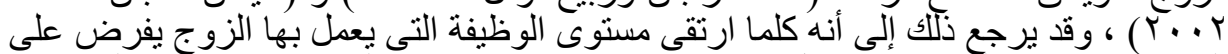

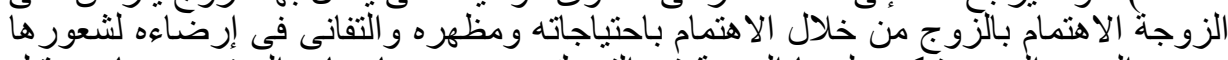

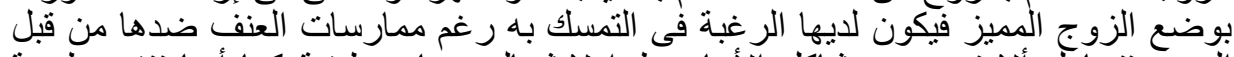

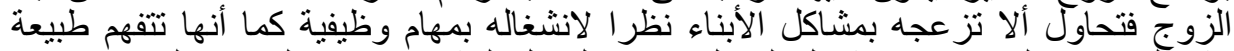

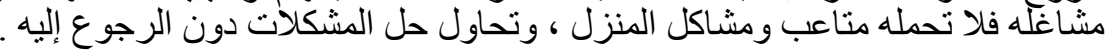




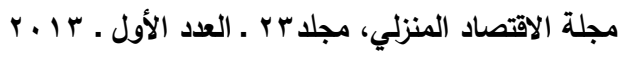

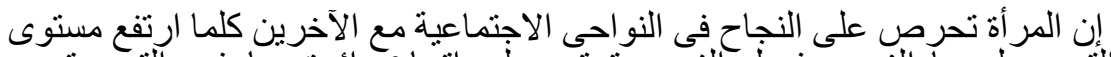

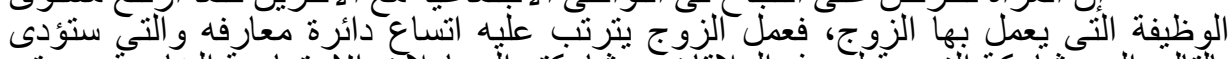

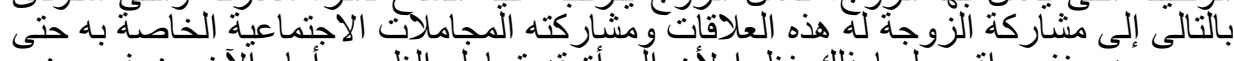

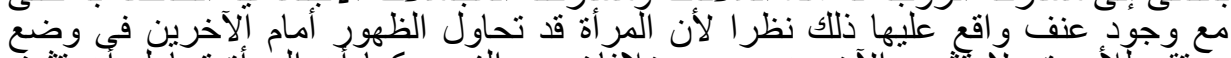

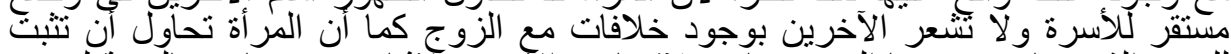

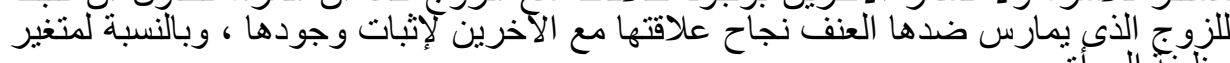

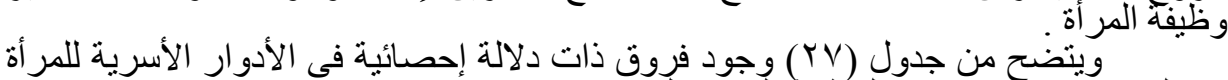

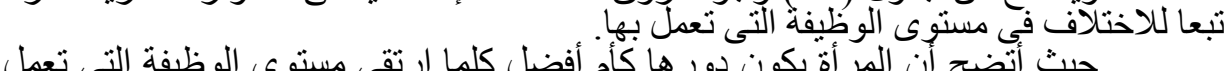

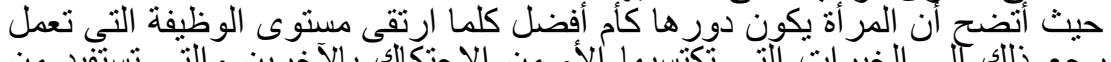

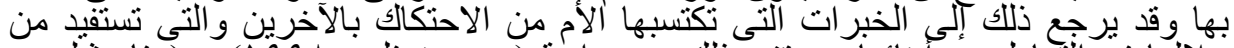

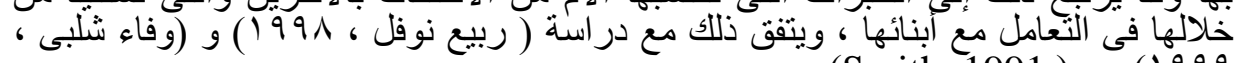

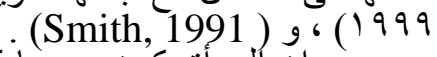
ان المر أة يكون دورها كزوجة أفضل كلما ارتقى مستوى الوظيفة التى تعمل بها فقد

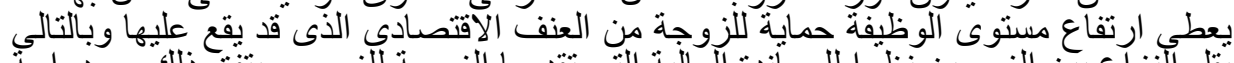

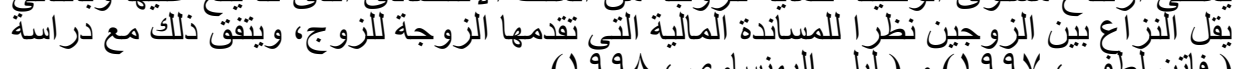

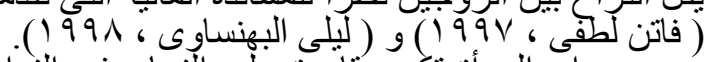

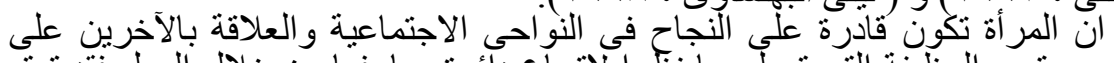

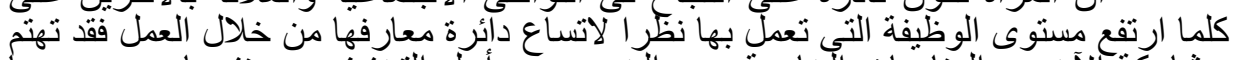

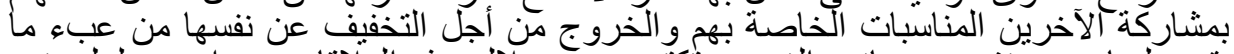

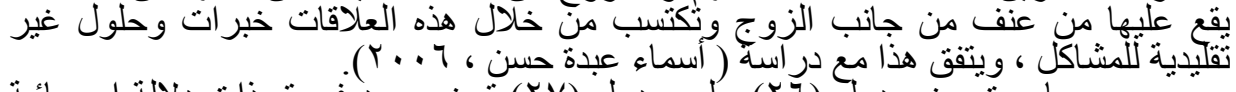

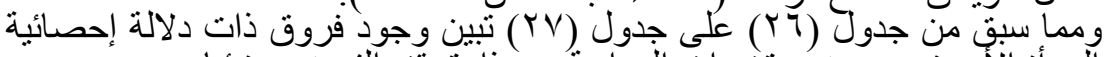

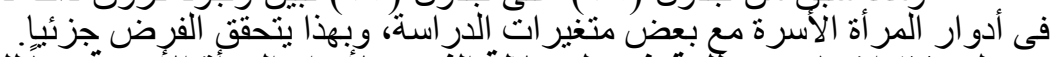

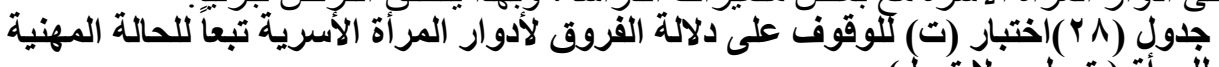

\begin{tabular}{|c|c|c|c|c|c|c|}
\hline الدلالة & (تيمة & الحرجية & العينة & الأنحر اف & الحسابى & دور الأم \\
\hline \multirow{2}{*}{ ' تُعمل دال } & \multirow{2}{*}{11.704} & \multirow{2}{*}{111} & $\sum 9$ & $10 . \mathrm{VV}$ & AT.VTO & تعمل \\
\hline & & & $\overline{V I}$ & $7.00 \leqslant 1$ & ह1.0\%० & لا تعمل \\
\hline الدلالة & قيمة & الحرية & العينة & الالمعيارى اف & الحسابى المت & دور الزوجة \\
\hline \multirow{2}{*}{ لصنالح لال } & \multirow{2}{*}{$10.9 \times 1$} & \multirow{2}{*}{111} & $\leq 9$ & $17.11 \wedge V V$ & $q 4 . r \leq 7 q$ & تعمل \\
\hline & & & vi & 11.11 .19 & or.1179 & لا تعمل \\
\hline الدلالة & قتيمة & الحرية & العينة & الالنحريارى اف & الحستوسط & المور ربة \\
\hline \multirow{2}{*}{ ' تُعمل دال } & \multirow{2}{*}{$\varepsilon . \leqslant \leqslant 0$} & \multirow{2}{*}{111} & $\sum 9$ & $1 \leqslant . r 01$ & $\Lambda I V \Psi \leqslant V$ & تعمل \\
\hline & & & VI & TY.Y. & $V \cdot .9 \cdot 1 \leq$ & لا تعمل \\
\hline الدلالة & قيمة & الحرية & العينة & الالحعيارى اف & الحسابى المتوسط & الاجنماعية الني \\
\hline \multirow{2}{*}{ غير دال } & \multirow{2}{*}{$1.0 \leq$} & \multirow{2}{*}{111} & $\sum 9$ & $1 T . \leqslant 00$ & $r q . \wedge 9 \wedge$. & تعمل \\
\hline & & & VI & $1 Y .7 \mathrm{VV}$ & $\varepsilon 0 . M Y \varepsilon$ & لا تعمل \\
\hline
\end{tabular}




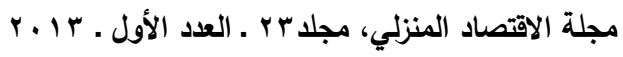

يتضح من جدول (Y^) وجود فروق ذات دالالة إحصائية فى أدوار المرأة الأسرية

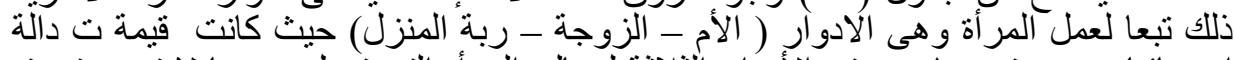

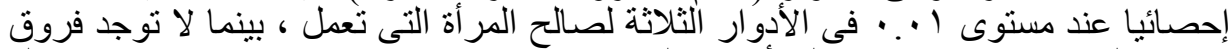

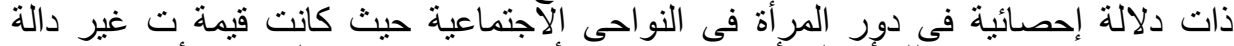

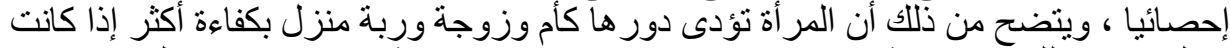

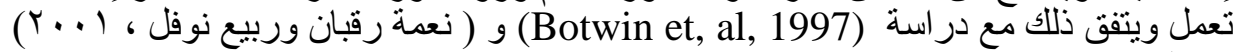

ويتعارض مع (Smith 1991, Cansian, 1993) .

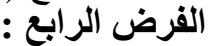

توجد علاقة ارتباطية بين أثنكال وأسباب العنف الذى تتعرض له اله المرأة من قبل

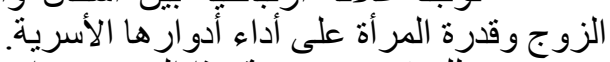

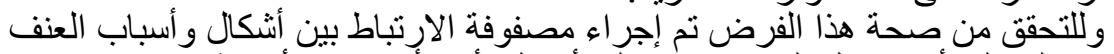

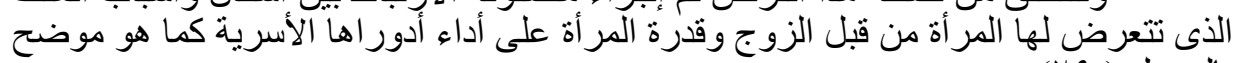

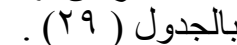

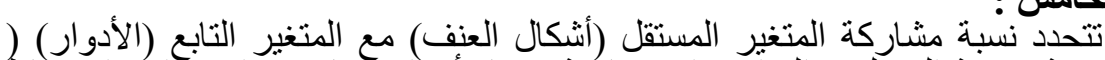

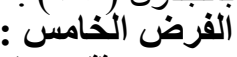

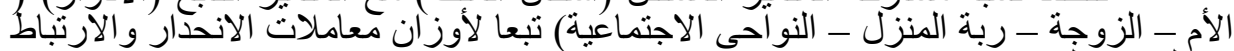

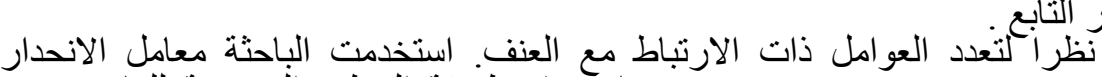
مع المتغير التنابع.

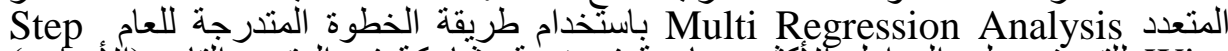
ولت للتعرف على العو امل الأكثر مساهمة فى نسبة مشاركة في المتغير النتابع (الأدوار )

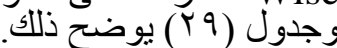
جذول (Y9 Y ) معاملآت الانحدار باستخدام الخطوة المتدرجة الى الأمام Step Wise

\begin{tabular}{|c|c|c|c|c|c|c|c|c|}
\hline الدلالة & قيمة (ت) & الانحدار & الدلالة & قيمة (ف) & المشازبة كة & الارتباط & المستقبيل & المتغير التابع \\
\hline$\because \cdot 1$ & $r \cdot r q r$ & . & $\because \cdot 1$ & $\varepsilon 10 . \wedge$ ro & $\because \vee \vee q$ & $\cdot \wedge \wedge \mu$ & معنوى & \multirow{3}{*}{ دور الأم } \\
\hline$\because \cdot 1$ & $\vee . \vee 9 \wedge$ &.$|V|$ & $\because \cdot 1$ & $7 \cdot \Lambda \cdot \Lambda$ & $\cdot r \varepsilon$. & .01. & مادى & \\
\hline$\because \cdot 1$ & $\varepsilon . q \cdot V$ & .110 & $\because \cdot 1$ & $r \varepsilon . \wedge l$ & .179 & $\cdot \varepsilon \mid r$ & اقتصادى عنف & \\
\hline$\because \cdot 1$ & 11.014 & מ r r & $\because \cdot 1$ & $r \leqslant r .091$ & $\because V \leq \varepsilon$ & •.人Tr & مادى عنف & \multirow{3}{*}{ دور الزوجة } \\
\hline$\because \cdot 1$ & $1 . r 77$ & .111 & $\because \cdot 1$ & 79.919 & . rVT & .71 & معنوى & \\
\hline$\because \cdot 1$ & $7.9 V Y$ & .100 & $\because \cdot 1$ & $\varepsilon \wedge.\urcorner \cdot r$ &.$r q r$ & $\because 0 \leq$. & اقتصادى عنف & \\
\hline$\because \cdot 1$ & $1 \varepsilon .07$. & $\because r V V$ & $\because \cdot 1$ & $r 11.994$ & $. T \leq Y$ & $\cdot \Lambda \cdot r$ & مادى & \multirow{3}{*}{ دالمنزل بنة } \\
\hline$\because \cdot 1$ & I T.VYO & r ror & $\because \cdot 1$ & $174.19 \leq$ & $.0 \Lambda$. &.$V 7 r$ & اقتصادى عنف & \\
\hline$\because \cdot 1$ & 9.10. & $\cdot r \cdot T$ & $\because \cdot 1$ & $9 V .117$ &.$\leqslant 01$ &.$T V Y$ & معنوى معن & \\
\hline$\because \cdot 1$ & 17.11 & $\because r 9 \wedge$ & $\because \cdot 1$ & ro1.7.9 & $.7 \wedge \mathrm{V}$ & $\because \wedge r q$ & مادى & \multirow{3}{*}{ دورج الإجنواحية } \\
\hline$\because \cdot 1$ & 11.871 & $\cdot r \cdot T$ & $\because \cdot 1$ & 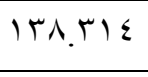 & $.0 \leqslant$. & . vro & معنوى & \\
\hline$\because \cdot 1$ & $\varepsilon .9 \cdot v$ & .110 & $\because \cdot 1$ & $r \varepsilon . \wedge 1$ & .179 &.$\leq \leqslant \leq 0$ & اقتصادى عنف & \\
\hline
\end{tabular}




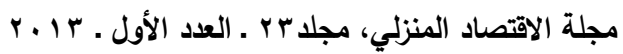

يتضح من الجدول (Y9) تأثثر أشكال العنف على الأدوار التى تقوم بها المرأة فى

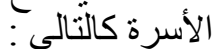

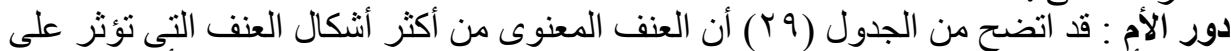

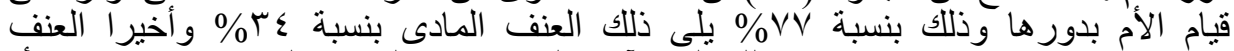

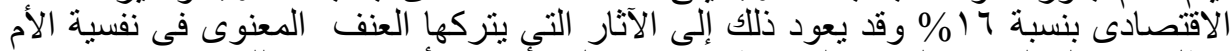

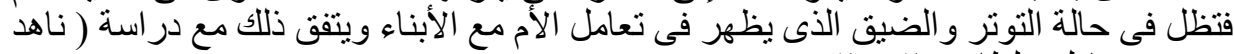

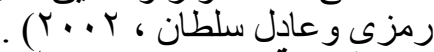

دور الزوجة : اتضح من جدول (Yq) أن العنف المادى من أكثر أنواع العنف التى تؤثر سلبيا

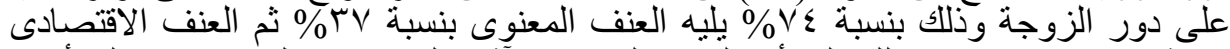

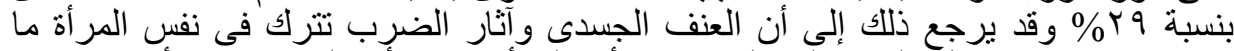

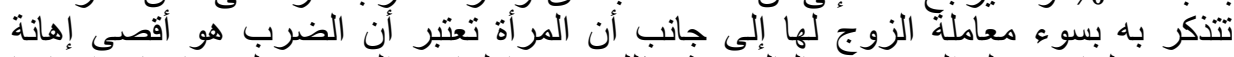

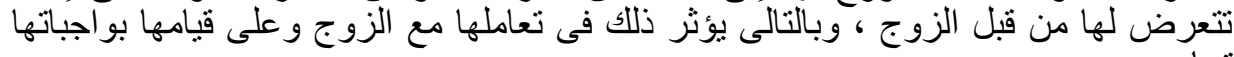

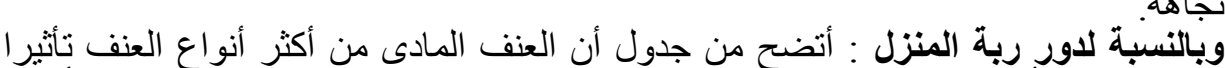

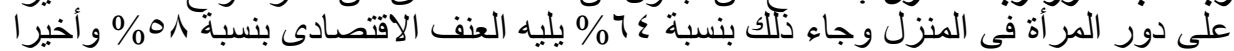

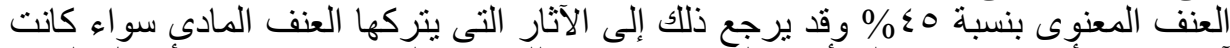

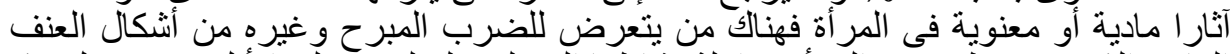

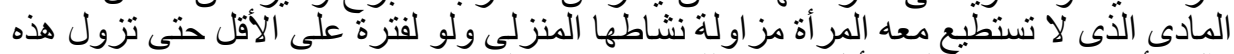

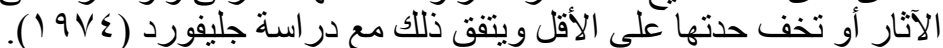

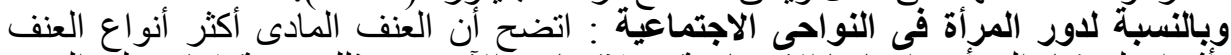

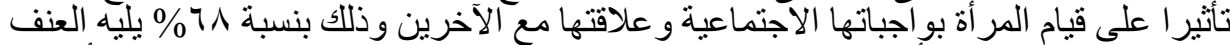

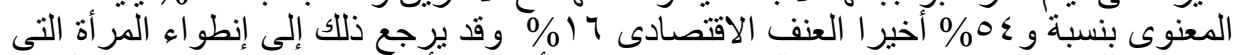

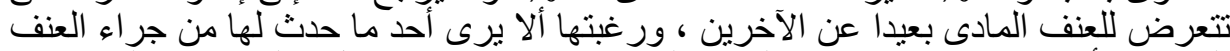

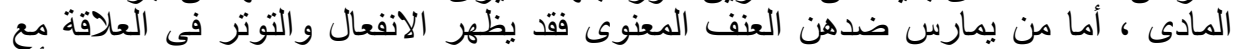

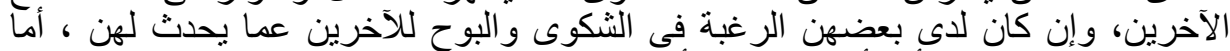

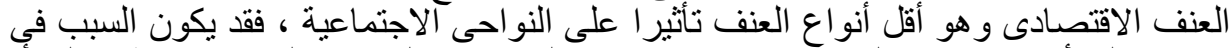

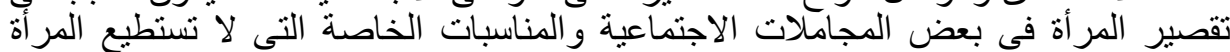

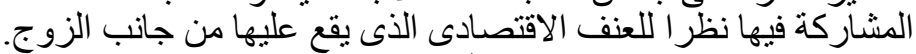

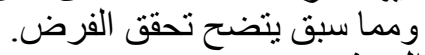
توصيات البحث : البمات

ا. أهتمام "الجهات المعنية بالمرأة مثل المركز القومى للمر أة و المركز القومى للأمومة

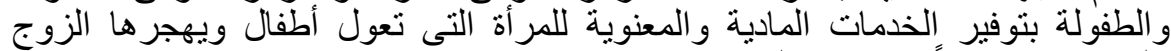

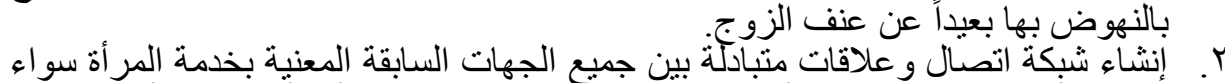

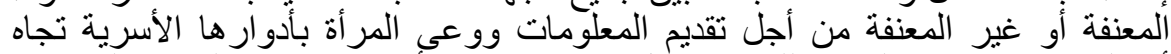

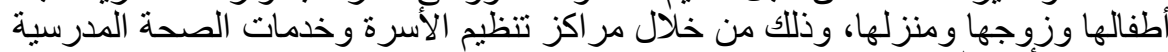

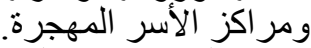

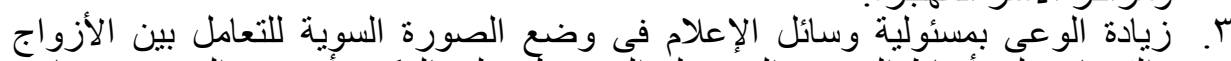

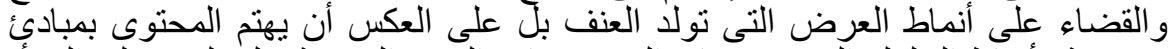

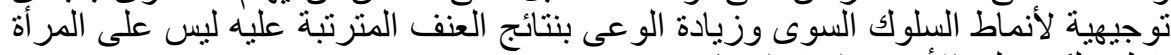
فقط، ولكن على الأسرة واستقر ارها. 


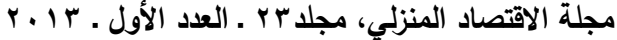

؛. الاهتمام بدعم البحوث المتعلقة بالعنف ضد المرأة وجمع البيانات وتجميع الإحصاءات

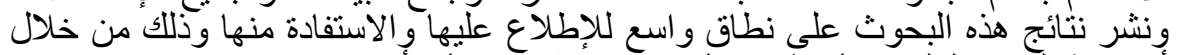

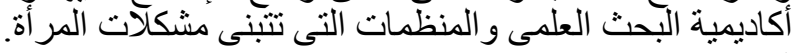

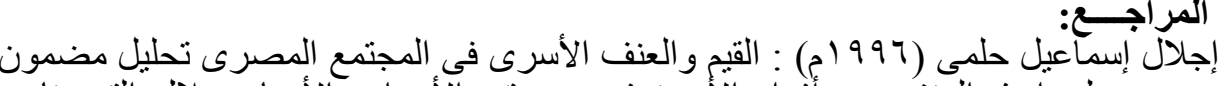

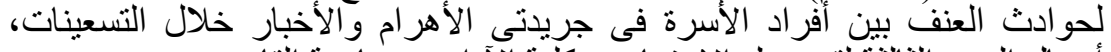

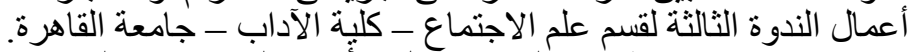

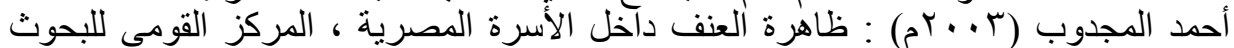
الاجنماعية و الجنائية ، القاهرة.

أحمد عبد الله زايد (99191م) : الأسرة والطفوة الطفولة - دراسات اجتماعية وانثروبولوجية، طا ، دار المعرفة الجامعية ، الإسكندرية.

أحمد عبد الله زايد (r . .rم) : المرأة وقضائا المجتمع - مركز البحوث و الدراسات الاجتماعية

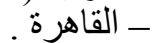

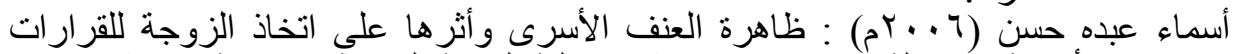

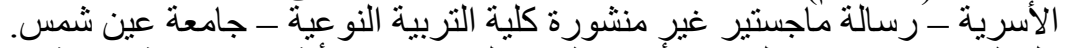

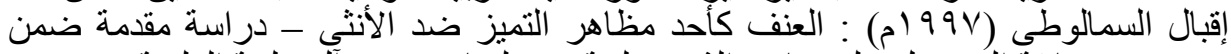

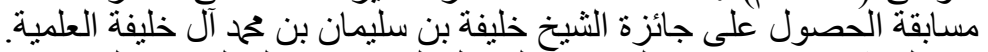

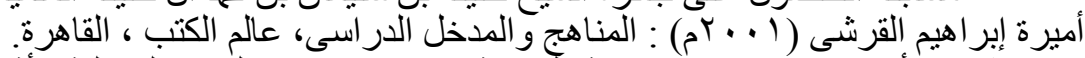

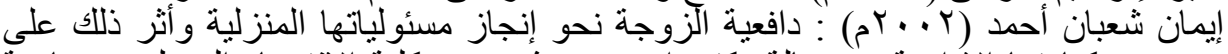

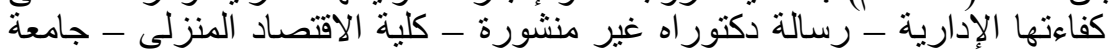

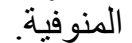

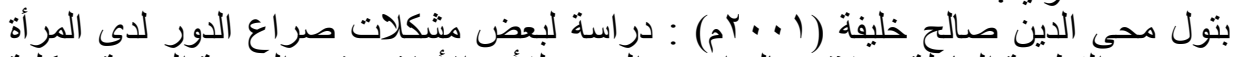

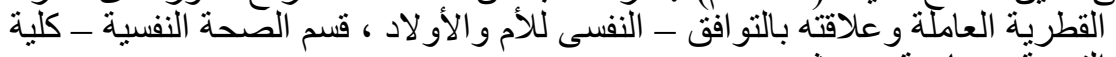

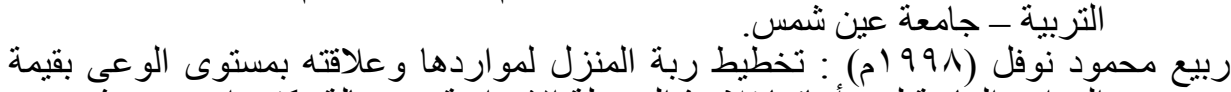

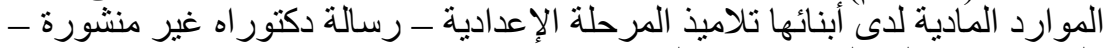

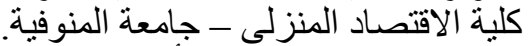

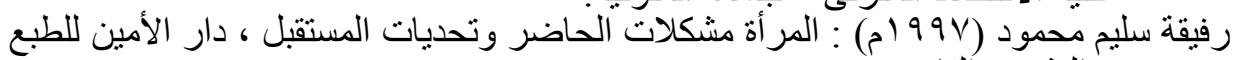

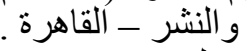

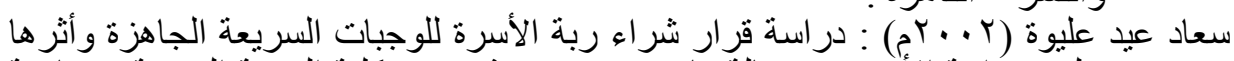

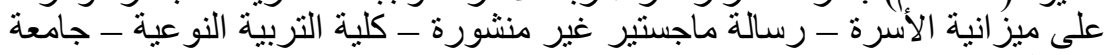

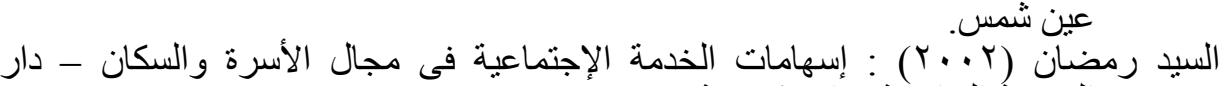
المعرفة الجامعية - الإسكندرية.

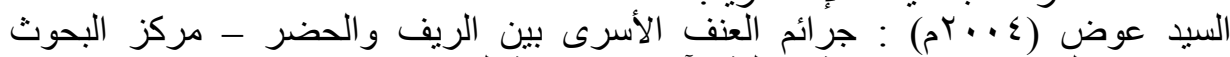

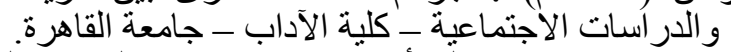

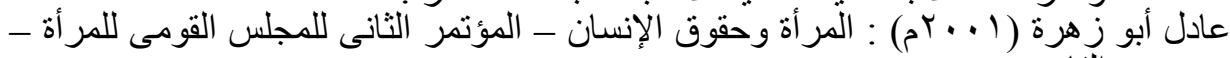

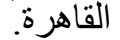

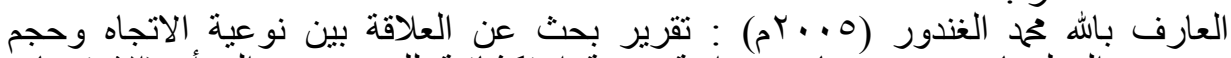

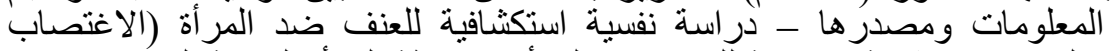

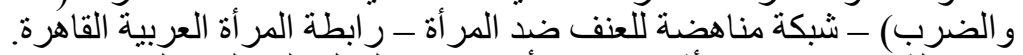

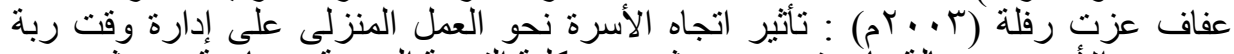
الأسرة - رسالة ماجستير غير منشورة - كلية التربية النوعية - جامعة عين شمس. 


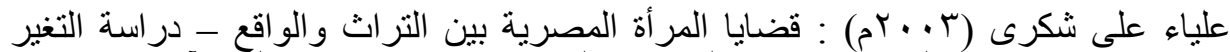

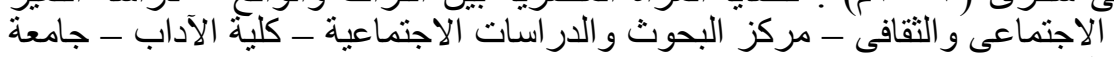

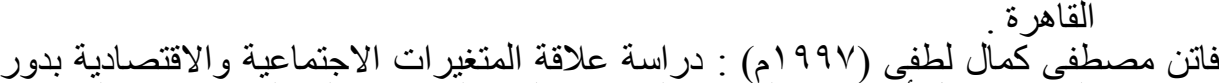

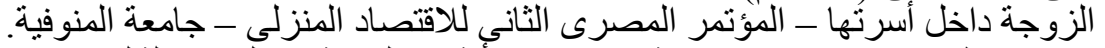

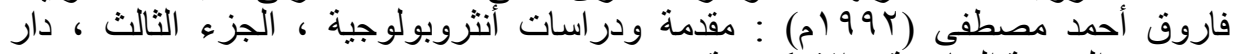
المعرفة الجامعية ـ الإسكندرية.

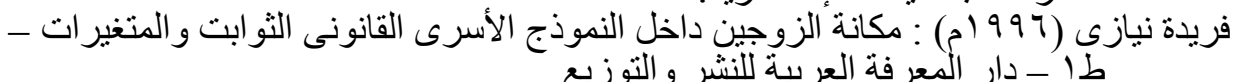

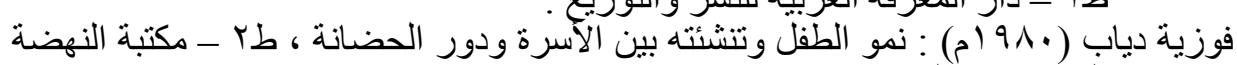

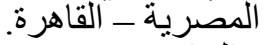

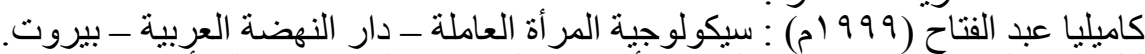

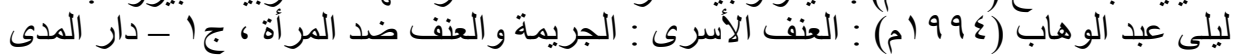

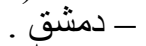

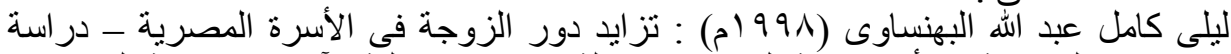

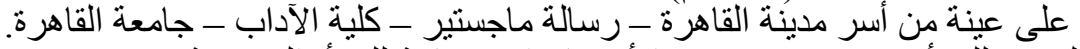

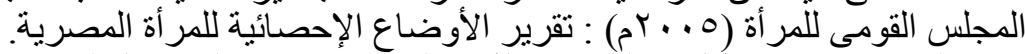

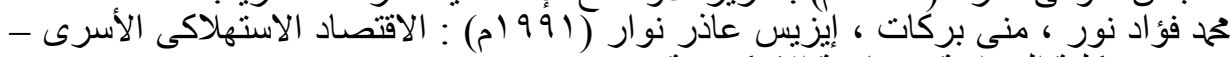
كلية الزراعة - جامعة الإسكندرية.

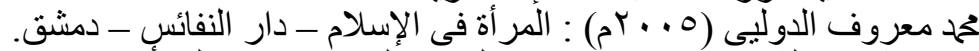

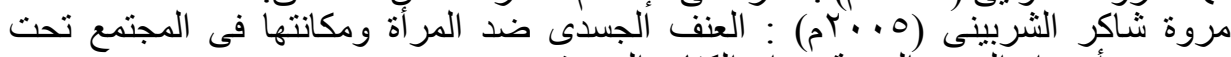
أضواء السيرة النبوية - دار الكتاب الحديث.

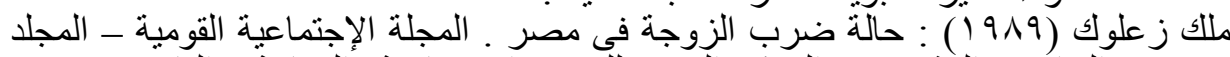

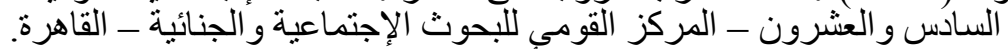

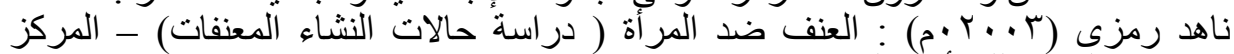

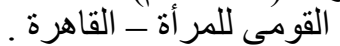

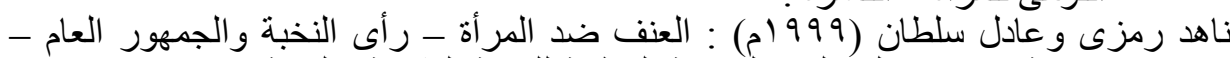

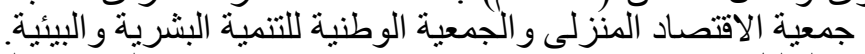

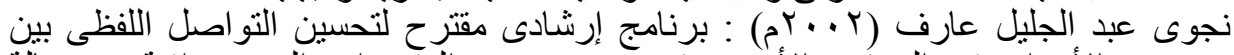

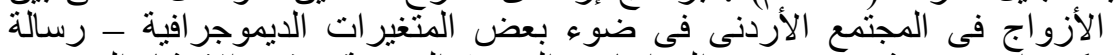

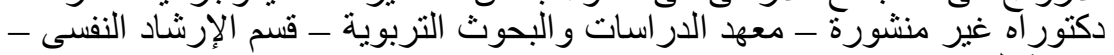
جامعة القاهرة .

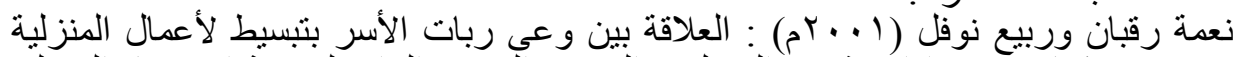

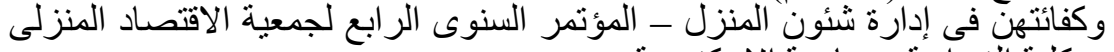
- كلية الزراعة إعة - جامعة الإسكندرية.

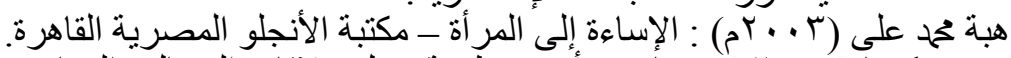

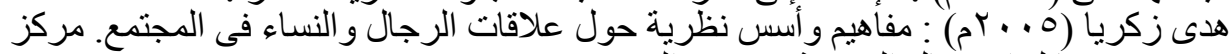

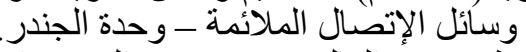

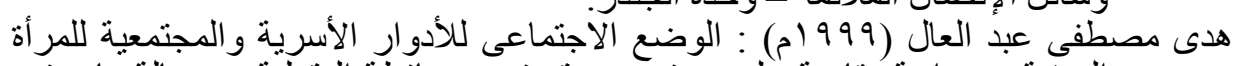

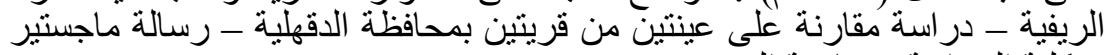

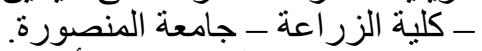

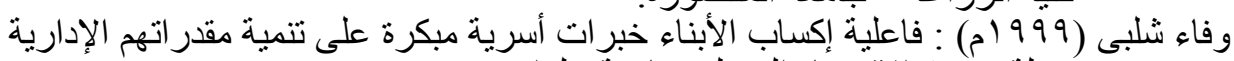
- مجلة بحوث الاقتصاد المنزلى جامعة حلو الابناه 


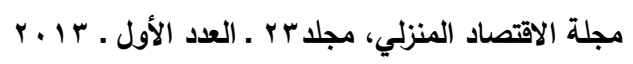

Botwin, M, et al. (1997): Personality and mate preference, fire factors in mate section and marital satisfaction, journal of personality

Concian, M, (1993 ) : working woman and its effect on take decision family and success the marriage.

FayloureM, Master's (1977) : Role per for manse of husbands and wives in financial management kens as stets university Manhattan Kansas interlibrary lean.

Gelles, R \& straus, M (1979) determinates of violence in the family toward theoretical. Integration in B. Wesley \& $\mathrm{H}$ Reuben (Eds) contemporary. Theories About the family New York the prepress.

Godwin, d and Konnce. E (1992): Family cash flow and its consequences: does the text book advice work? Proceeding of the 1992 south Easters regional association of family economics and home management climbs. The oho state university.

Henderson, Alen (1996) : Family violence. Journal of family violence, N. (20).

Kazarion, Iz (1986) : cultural aspects of family violence in : Kazarian \& Devens (eds) cultural clinical psychology: New York: Oxford university press.

Moziok, W \& As far, T (2003) : physical abuse in low-income. Woman in Aleppo. Syria, health care for woman international, 24 (4).

Murphy, C \& oleary, F (1994): dependence character is tics of partner assault man, journal of abnormal psychology vol. 103 (1).

Richard gelles (1972) : the violent home, sage library of social research, 13 sage publication.

Smith, J (1991): the effect of mother's work on adds. Cent's achievement- Motive and their level of as privation in Poland dissertation abstract international, vol. 32-6-1563

United national (2000): oscine console. Council the woman in 2000. gender equality development and peace. 21 century document No. E.ICN New York. 


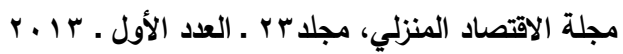 \\ Practicing Violence against women and its Effect on her family roles Performance
}

\author{
Gilan Salah El-Din Al-Qabbani ${ }^{1}$, Naglaa Sayed Hussein ${ }^{2}$ \\ Prof.of of Management ${ }^{1}$, Assistant Professor of Management ${ }^{2-}$ Family Institutions and \\ Childhood Department Faculty of Home Economics - Helwan University
}

\begin{abstract}
:
This research aims to detect the impact of violence against women on the performance of the roles of family, and the research was conducted on a sample of 120 married women from the levels of different economic and social has stipulated that a woman from a family matrimonial composed of husband and wife and children and have a family one childat least to examine the role of the mother and may be subjected to violence repeatedly on the part of the husband. follow in search descriptive analytical method, and use the search form public statements to members of the research sample, a questionnaire of violence against women, a questionnaire family roles of women. And has statistical processing CNC program SPSS statistical and transactions of used test (P) F.TEST \& test (T) T.TEST, in addition to the frequencies and percentages

\section{The results Search for:}

1. There were statistically significant differences in the forms of violence against women members of the research sample by the husband (physical - moral - economist) depending on the independent variables (level of education of the pair - level of education of the wife - the income level of the family - a marriage the level and function of the pair -the professional status of women the level and function of the pair), and at the level of significance $(0,01)$.

2. The presence of statistically significant differences in the causes of violence against women members of the research sample by the pair depending on the independent variables following (Education husband, education wife, family income, duration of marriage, the function of the wife, the situation women's professional function, the wife) and at the level of significance $(0,01)$.
\end{abstract}




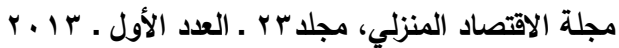

3. The presence of statistically significant differences in the roles of women family depending on the different variables of the study (Education husband, education wife, family income, duration of marriage, the function of the pair, the situation professional women Function wife) and at the level of significance $(0,01)$.

4. The presence of correlation between the forms and causes of violence against women by a husband and a woman's ability to perform their roles and family at the level of significance $(0,05)$.

5. The presence of statistically significant differences in the rate of participation of the independent variable (violence) with the dependent variable (roles) (mother - wife - housewife - the social aspects) depending on the weights of the regression coefficients and correlation with the dependent variable, and at the level of significance (0.01) .

And interesting The recherché recommends that women stakeholders such as the National Center for Women and the National Center for Childhood and Motherhood to provide moral and material services for women who count children and Abandons the pair to the advancement of them away from the violence of the husband . 